Review

\title{
Novel CRISPR-Cas Systems: An Updated Review of the Current Achievements, Applications, and Future Research Perspectives
}

\author{
Sweta Nidhi ${ }^{1,+}$, Uttpal Anand $\left.^{2,+}{ }^{(}\right)$, Patrik Oleksak ${ }^{3}{ }^{(}$, Pooja Tripathi ${ }^{4}$, Jonathan A. Lal ${ }^{5}$, George Thomas ${ }^{5}(\mathbb{D}$, \\ Kamil Kuca ${ }^{3, *(1)}$ and Vijay Tripathi ${ }^{5, *}$ (i)
}

check for

updates

Citation: Nidhi, S.; Anand, U.; Oleksak, P.; Tripathi, P.; Lal, J.A.; Thomas, G.; Kuca, K.; Tripathi, V. Novel CRISPR-Cas Systems: An Updated Review of the Current Achievements, Applications, and Future Research Perspectives. Int. J Mol. Sci. 2021, 22, 3327. https:// doi.org/10.3390/ijms22073327

Academic Editors: Eric B. Kmiec and Brett Sansbury

Received: 13 February 2021

Accepted: 19 March 2021

Published: 24 March 2021

Publisher's Note: MDPI stays neutral with regard to jurisdictional claims in published maps and institutional affiliations.

Copyright: (c) 2021 by the authors Licensee MDPI, Basel, Switzerland. This article is an open access article distributed under the terms and conditions of the Creative Commons Attribution (CC BY) license (https:// creativecommons.org/licenses/by/ $4.0 /)$
1 Department of Genomics and Bioinformatics, Aix-Marseille University, 13007 Marseille, France; swetanidhi4@gmail.com

2 Department of Life Sciences and the National Institute for Biotechnology in the Negev, Ben-Gurion University of the Negev, Beer-Sheva 84105, Israel; ushuats@gmail.com

3 Department of Chemistry, Faculty of Science, University of Hradec Kralove, 50003 Hradec Kralove, Czech Republic; patrik.oleksak@uhk.cz

4 Department of Computational Biology and Bioinformatics, Jacob Institute of Biotechnology and Bioengineering, Sam Higginbottom University of Agriculture, Technology and Sciences, Prayagraj 211007, Uttar Pradesh, India; pooja.tripathi@shiats.edu.in

5 Department of Molecular and Cellular Engineering, Jacob Institute of Biotechnology and Bioengineering, Sam Higginbottom University of Agriculture, Technology and Sciences, Prayagraj 211007, Uttar Pradesh, India; jonathanalal@shiats.edu.in (J.A.L.); georgethomas@shiats.edu.in (G.T.)

* Correspondence: kamil.kuca@uhk.cz (K.K.); vijay.tripathi@shiats.edu.in (V.T.)

+ These authors contributed equally to this work.

\begin{abstract}
According to Darwin's theory, endless evolution leads to a revolution. One such example is the Clustered Regularly Interspaced Palindromic Repeats (CRISPR)-Cas system, an adaptive immunity system in most archaea and many bacteria. Gene editing technology possesses a crucial potential to dramatically impact miscellaneous areas of life, and CRISPR-Cas represents the most suitable strategy. The system has ignited a revolution in the field of genetic engineering. The ease, precision, affordability of this system is akin to a Midas touch for researchers editing genomes. Undoubtedly, the applications of this system are endless. The CRISPR-Cas system is extensively employed in the treatment of infectious and genetic diseases, in metabolic disorders, in curing cancer, in developing sustainable methods for fuel production and chemicals, in improving the quality and quantity of food crops, and thus in catering to global food demands. Future applications of CRISPR-Cas will provide benefits for everyone and will save countless lives. The technology is evolving rapidly; therefore, an overview of continuous improvement is important. In this review, we aim to elucidate the current state of the CRISPR-Cas revolution in a tailor-made format from its discovery to exciting breakthroughs at the application level and further upcoming trends related to opportunities and challenges including ethical concerns.
\end{abstract}

Keywords: CRISPR/Cas9; genome editing; agricultural production; livestock; industrial applications; therapeutics

\section{Introduction}

The very beginning of this exciting Clustered Regularly Interspaced Palindromic Repeats (CRISPR) story dates back to the observations published by a Japanese research group in 1987 [1]. However, Ishino and his colleagues could not explain much about the biological significance of their identified sequences that contained five homologous sequences of 29 nucleotides separated by spacers of 32 nucleotides. The discovery of similar mysterious arrays of regularly spaced repeated sequences was continued by later research groups that gradually revealed their biological significance [2]. The universally accepted 
CRISPR acronym, Clustered Regularly Interspaced Palindromic Repeats, was coined by a Spanish microbiologist, Mojica [3]. The inquisitive journey that led to the CRISPR discovery, the contributors involved, and their achievements are adequately demonstrated in the literature.

In the journey from the initial observations to the current breakthrough of CRISPR science and technology that has flourished, bloomed, and continued to bear fruits through the past three decades, with many success stories, the scientific attention has gradually turned to reap the benefits of this gene-editing technology while the science that supported this technology is left aside. At this juncture, CRISPR researchers should remember that the foundation of this groundbreaking technology boom was systematic understanding of CRISPR biology and that the abundance of scientific ignorance once left out from this virgin area of molecular biology consists of many gold mines worthy of future research. Hence, along with ongoing advancements in the utilization of CRISPR technology, there is a pressing need to continue exploring its structural features; however, the existing knowledge on these aspects is spread over various articles in the literature. In view of reorganizing the existing information spread and of the pressing need for their systematic analyses, the current review was constructed. This article encourages upcoming CRISPR scientists and subsequently elaborates on the strengths of further scientific inquiry instead of the former scientific ignorance of this novel and unexploited area.

The CRISPR-Cas system is an adaptive immune system in prokaryotes that prevents phage infection by storing memory in the form of viral DNA in bacterial host chromosomes. The system contains viral DNA surrounded by repetitive nucleotide sequences called direct repeats. These direct repeats are surrounded at the near end by sequences encoding proteins called Cas proteins. This system was artificially manipulated in guiding reprogrammed endonucleases to the target gene. CRISPR is one genome editing techniques that modify internal DNA/RNA in a sequence-specific manner and is reprogrammable; CRISPR-associated endonuclease Cas proteins have been used in various ways to precisely modify genes, called gene editing. It has been applied successfully in the field of agriculture, in therapeutics and infectious agents, in food industries, and bioenergy.

The topics covered in the current review focus on (i) elucidating the mechanism of action in different CRISPR systems; (ii) describing the structure of effector complexes in CRISPR; (iii) detailing and summarizing the current benefits of CRISPR-Cas application in plant biotechnology, therapeutics, and the food industry; and (iv) discussing the effects and limitations of the CRISPR technology upon reckless use. In addition, we shed some light on the limitations of CRISPR, providing ethical concerns.

\section{The CRISPR-Cas System}

2.1. History of the CRISPR-Cas System

(a) Identification phase: 1987-1993

The first encounter with the five direct repeats containing 24 nucleotide repetitive sequences of the CRISPR-Cas system was in 1987 during the identification of the gene responsible for the conversion of alkaline phosphatase isozyme in Escherichia coli [1]. The second occurrence was in Haloferax mediterranei containing 30-34 nucleotide sequences, with direct repeats spaced by $35 \mathrm{bp}$ long sequences called a spacer. The direct repeats also contained short, inverted repeats similar to that in the former sequence [4]. During the time phase from 1987 to 1993, the variable sequences in between the direct repeats or spacers of the CRISPR-Cas system intrigued scientists.

(b) Structural and functional characterization phase: 1993-2011

The discovery of similar mysterious arrays of regularly spaced repeated sequences was continued by later research groups in archaea and bacteria and gradually led to their biological significance [2]. During the period from 1993 to 2005, Ruud Jansen and colleagues designated the repeated DNA sequences as Clustered Regularly Interspaced Short Palindromic Repeats (CRISPRs) in 2002, located in the genome near the "DNA repair system" [5]. These nearby genes, earlier understood as part of the DNA repair system, 
were found mainly accompanying CRISPR genes and, therefore, were termed as CRISPRassociated (Cas) genes. (b) In 2005, two independent research studies linked the spacer's origin with bacteriophages [6,7]. (c) In 2006, Eugene V. Koonin and his collaborators computationally analyzed the link between the functions of CRISPR and Cas genes as a system and observed a similarity between this system and a prokaryotic RNA interference immune system [8]. (d) The CRISPR-Cas System (CCS) provides resistance to viruses, i.e., after a virus attack [9]. The spacers are stored in the host genome from the phage genomic sequences [2]. In 2011, Kira S. Makarova and coworkers gave an updated analysis of the evolutionary relationships between CRISPR and Cas proteins [10] followed by several papers in this direction.

(c) Application phase: 2011-ongoing

Thereafter, CRISPR research continued to bloom year after year in thousands of laboratories across the world; the success stories of this novel technology are schematically depicted in few articles. Identification of the CRISPR array and its associates in archaeal and bacterial genomes as efficient defense mechanisms for survival and protection against viral invasion was repurposed as a gene-editing technology to modify eukaryotic genomes that created enormous applications in various field of biology extending from medicine to agriculture. Transfer and reprogramming of the CRISPR-Cas system were conducted immensely in this period. A study showed CRISPR-Cas9 system transfer from Streptococcus thermophilus to Escherichia coli providing immunity against plasmid and phage infestation [11]. David Bikard and coworkers engineered Cas9 as a transcriptional repressor preventing binding of RNA polymerase (RNAP) to promoter sequences or hindering RNAP [12]. This was proven an asset in the field of gene regulation and synthetic biology and biotechnological applications. With more research, the toolbox of the CRISPR-Cas system improved, and simultaneously, its application flourished. This review focuses on comprehensive detailing of the CRISPR-Cas system's application in various fields of agriculture, animal husbandry, health, and diseases, etc. The history of the CRISPR-Cas system is summarized in Figure 1.

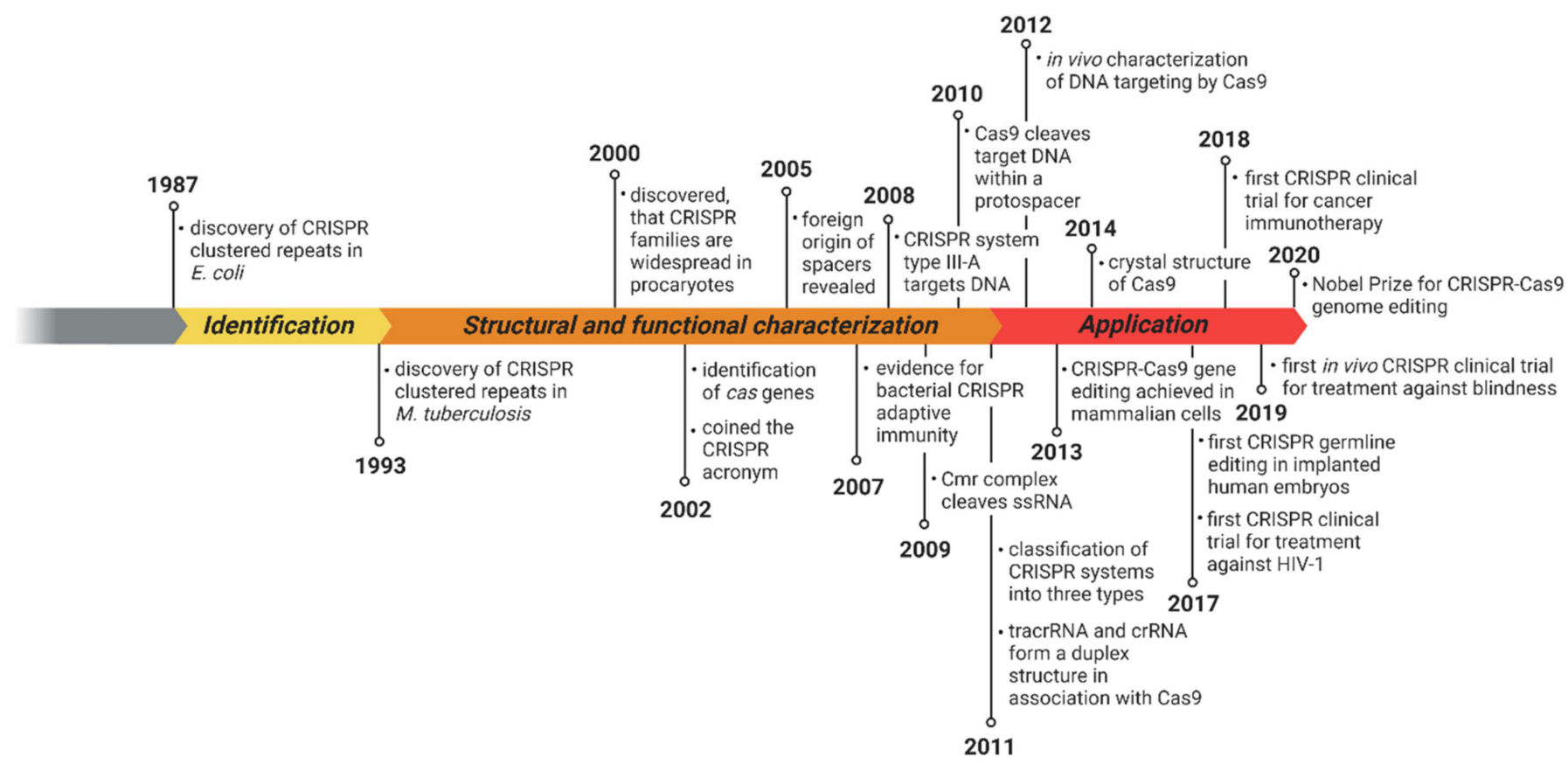

Figure 1. Timeline of the Clustered Regularly Interspaced Palindromic Repeats (CRISPR)-Cas system with important milestones; figure created with BioRender.com (accessed on 15 February 2021). 


\subsection{Function of the CRISPR-Cas System}

In the beginning, the function of CCS remained hidden. The wide presence of CCS in Bacteria and Archaea only informed us about the link between CCS and bacteriophage resistance. The scientific community was therefore more focused on finding the reason behind the former link. Their hard work paid off when the group led by Rodolphe Barrangou and coauthors [9] found that, after a viral infection, new spacer sequences from the invading bacteriophage (genomic inserted viruses) were inserted into the genome of the host. Any addition or removal of these inserted spacer sequences altered the phenotype of phage-resistance of the cell [9]. Many influential works led us to deduce the path of the functions. The important functional steps of the CRISPR system are adaptation, expression, and interference.

(1) Adaptation, also termed as insertion or acquisition, is a process of foreign DNA sequence incorporation into CRISPR arrays (Figure 2). Integration of a new spacer is mediated by the heterohexameric protein complex $\left(\left(\mathrm{Cas} 1_{2}-\mathrm{Cas} 2\right)_{2}\right)$ to the leader sequence of the CRISPR array. There are two different types of spacer acquisition system named type I and type II. A type I system utilizes integration host factor (IHF) bonded to the leader sequence, which induces DNA bending. This bending enables the (Cas1 $1_{2}$-Cas2 $)_{2}$ complex to perform an initial cleavage for insertion of the spacer. In a type II system, the leader anchoring sequence (LAS) of the leader is recognized using the Cas1 protein of the (Cas $\left.1_{2}-\mathrm{Cas} 2\right)_{2}$ complex and, then, the polar spacer is inserted [13].

(2) Expression, also termed CRISPR RNA (crRNA) biogenesis or crRNA processing, represents the transcription of a CRISPR array into a long precursor CRISPR RNA (pre-crRNA). Further processing involves the cleavage of pre-crRNA within each direct repeat sequence to afford shorter, mature CRISPR RNAs (crRNAs). Some crRNAs can further undergo $5^{\prime}$ end or $3^{\prime}$ end trimming. The enzymes involved in crRNA processing differ among types, in some cases, even among subtypes of the CRISPR-Cas system (Figure 3) [15].

(3) Interference involves the formation of a multiprotein effector complex or single effector protein. The multiprotein effector complex is typical for class 1 systems and consists of multiple Cas proteins and crRNA. The single effector protein is utilized in class 2 systems and contains only a single Cas protein with crRNA. The primary purpose of both complexes is to recognize the same or very similar sequences in the genome of the invading virus or plasmid. After recognition, the invading genome is cleaved by the complex and inactivated [14]. The interference step of some systems requires recognition of a protospacer adjacent motif (PAM) in the invading genome. The PAM is a short DNA sequence that is not present in the bacterial host genome. Hence, PAM is an essential targeting sequence to bind for some Cas proteins, followed by cleavage (Figure 3) [16]. 


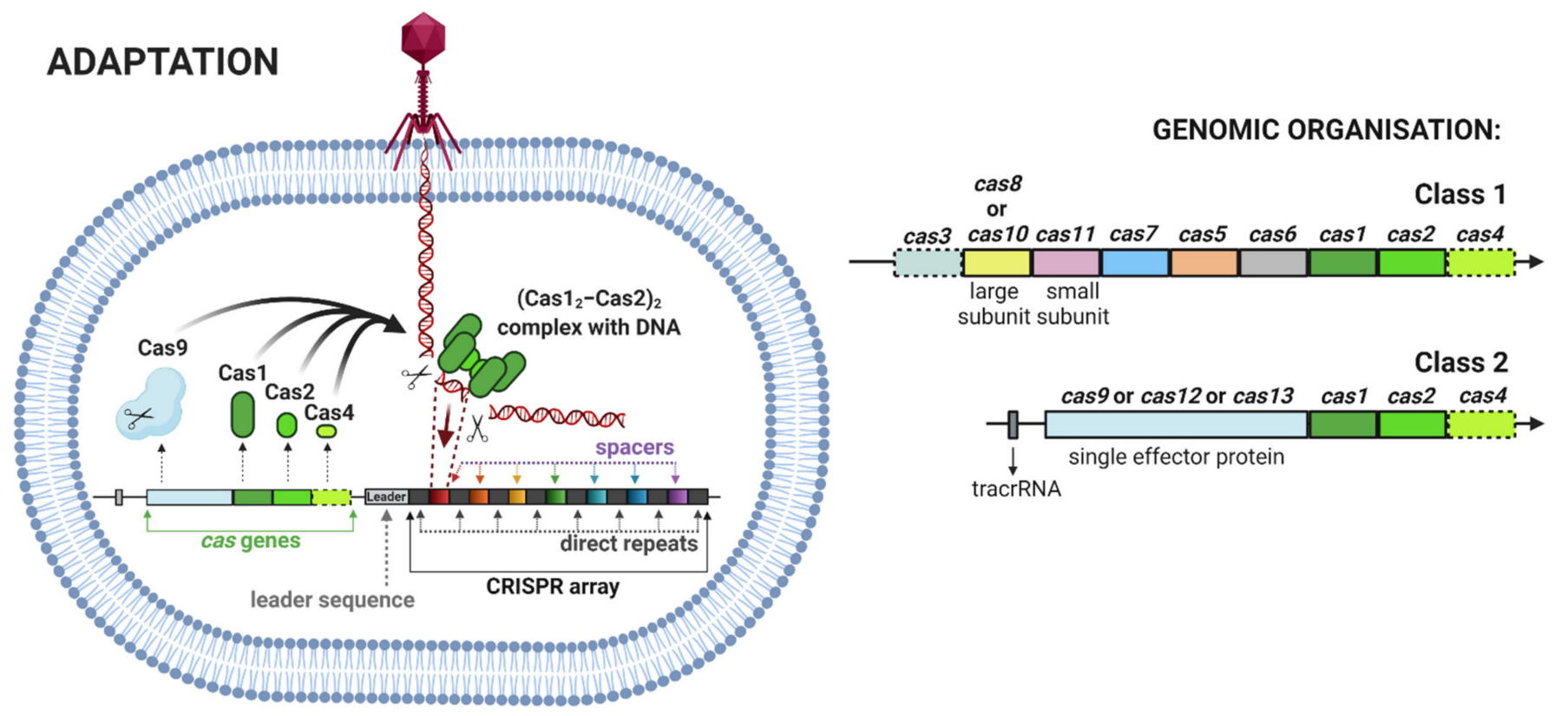

Figure 2. Left side: CRISPR adaptation step [2,9,10,14]. Right side: Generalized genomic organization in class 1 and class 2 systems. A dashed outline indicates that the gene is dispensable or missing in some subtypes or variants [14]. The figure was created with BioRender.com (accessed on 20 March 2021).

\subsection{Structure of CRISPR Locus and Classification of Cas Proteins}

The chromosomes of prokaryotic species generally contain one CRISPR locus [3]; however, several species contain more (up to eight) CRISPR loci [17]. The CRISPR locus consists of three major parts:

- The CRISPR array consists of short, direct repeats bordered with spacers. The direct repeats are nucleotide sequences in the genome with identical sequence and length. The sequences of direct repeats can be similar in related species, but overall diversity among the species is wide. The average size of the repeats is $32 \mathrm{bp}$; however, the size may vary from 21 to $47 \mathrm{bp}$. The spacers are nucleotide sequences with a fixed length, but they are highly variable in sequences. The average size of spacers is from 20 to 72 bp [18].

- The leader sequence is commonly adjacent to the CRISPR array and is involved in adaptation and transcription. These regions exhibit only limited conservation in sequence. It was observed that leaderless CRISPR loci are inactive in adaptation but still able to contribute to crRNA-directed interference [19].

- CRISPR-associated (cas) genes represent a cluster of genes in varying orientation and order that code corresponding Cas proteins (Table 1). In summary, 93 different cas genes have been identified until now. These genes were classified into 35 families based on the sequence similarities [20]. Cas proteins play a major role in the acquisition and destruction of foreign sequences (Table 2). 

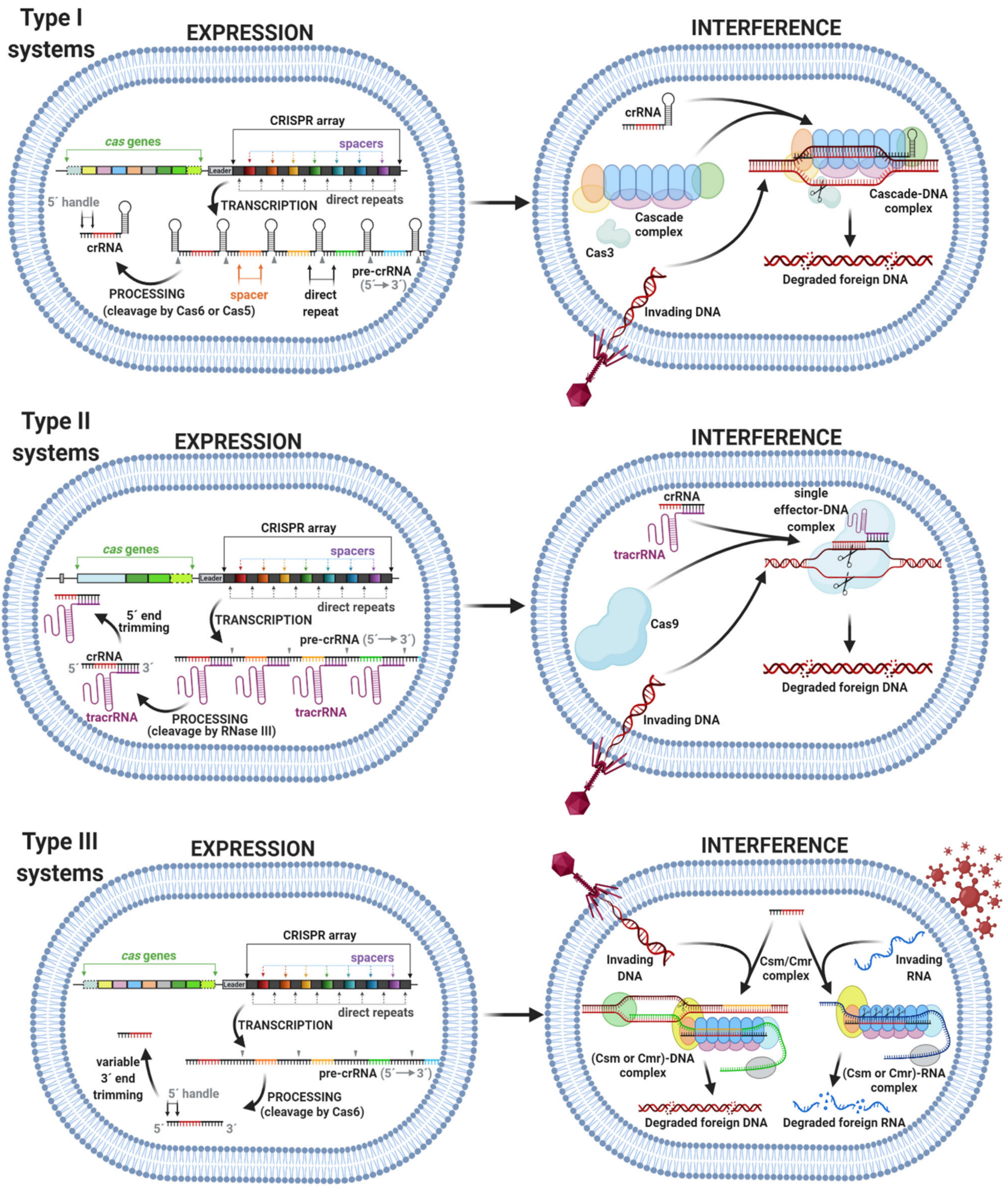

Figure 3. CRISPR expression and interference step in type I (top), type II (middle), and type III (bottom) systems. The figure was created with BioRender.com (accessed on 15 February 2021). 
Table 1. Selected Cas proteins and their functions. Types (Roman numerals) are colored black, and subtypes (Roman numerals with a letter) are colored gray [14,21].

\begin{tabular}{ccc}
\hline Protein & Association in Type or Subtype & Function \\
\hline Cas1 & $\begin{array}{c}\text { I, II, IV, IV (assumed) } \\
\text { III-A, III-B }\end{array}$ & DNA nuclease \\
\hline Cas2 & I, II, V & RNA nuclease \\
\hline Cas3 & I II-A, III-B, VI (some) & DNA nuclease and helicase \\
\hline Cas4 & II, V & DNA nuclease \\
\hline Cas5 & IV (most) & pre-crRNA processing \\
\hline Cas6 & I-C, III (some) & pre-crRNA processing \\
\hline Cas7 & I (most), III-A, III-B & RNA recognition, crRNA binding \\
\hline Cas8 & I, III, IV & large subunit of Cascade complex \\
\hline Cas9 & I (most) & DNA nuclease \\
\hline Cas10 & II & large subunit of Csm or Cmr complex \\
\hline Cas11 & I (some), III (most) & small subunit of effector complexes \\
\hline Cas12 & III & crRNA processing, DNA nuclease \\
\hline Cas13 & V (some), IV (some) & crRNA processing, RNA nuclease \\
\hline
\end{tabular}

Table 2. Cas protein association with CRISPR functional steps in type I-VI systems. An asterisk represents that protein being potentially fused to a large subunit in some subtypes. Underlined proteins are present in multiple copies. Proteins colored in gray are dispensable or missing in some subtypes or variants. Abbreviations: LS, large subunit; RT, reverse transcriptase; SS, small subunit; ?, unknown [14].

\begin{tabular}{|c|c|c|c|c|c|}
\hline & & \multirow{2}{*}{$\begin{array}{c}\text { Adaptation } \\
\text { Spacer Integration }\end{array}$} & \multirow{2}{*}{$\begin{array}{c}\text { Expression } \\
\text { pre-crRNA Processing }\end{array}$} & \multicolumn{2}{|c|}{ Interference } \\
\hline & & & & Effector Complex & Target Cleavage \\
\hline \multirow{3}{*}{ class 1} & type I & Cas1, Cas2, Cas4 & Cas6 & Cas7, Cas5, SS ${ }^{*}$, Cas8/LS & Cas3", Cas3' \\
\hline & type III & Cas1, Cas2, RT & Cas6 & Cas7, Cas5, $\underline{\text { SS, Cas10/LS }}$ & Cas10/LS \\
\hline & type IV & Cas1, Cas2 & Cas6 & Cas7, Cas5, SS, Csf1/LS & $?$ \\
\hline \multirow{3}{*}{ class 2} & type II & Cas1, Cas2, Cas 4 & RNase III & Cas9 & Cas9 \\
\hline & type V & Cas1, Cas2, Cas4 & Cas12 & Cas12 & Cas12 \\
\hline & type VI & Cas1, Cas2 & Cas13 & Cas13 & Cas13 \\
\hline
\end{tabular}

\subsection{Classification of the CRISPR-Cas System}

Classification of the CRISPR-Cas system is essential for understanding the origin and further research on the CRISPR system. The classification is based on differences in Cas protein composition and sequence divergence between the effector complexes. The evolutionary classifications of the CRISPR-Cas system were reported by Makarova et al. in 2011 [10], in 2015 [20], and most recently in 2020 [14]. These reports demonstrate an extensive interest in this area. According to the classification reported in 2020 [14], the CRISPR-Cas system is divided into 2 classes, 6 types, 33 subtypes, and several variants.

The class 1 system consists of type I, type III, and type IV systems (Table 3). This class utilizes an effector complex composed of multiple Cas proteins and crRNA in the interference step. The type I system contains 7 subtypes (I-A, I-B, I-C, I-D, I-E, I-F, and I-G) including several variants. The pre-crRNA in type I systems contains palindromic repeats that are either unstructured (subtypes I-A and I-B) or form hairpin structures (subtypes I-C, I-D, I-E, and I-F). The cleavage of pre-crRNA in a type I system is generally mediated 
by Cas6 protein; however, cleavage in subtype I-C systems is mediated by a Cas5 protein. The CRISPR-associated complex for an antiviral defense (Cascade) complex is an effector complex for the interference step in type I systems. The Cascade complex usually contains Cas3, Cas5, Cas7, Cas8, and other Cas proteins in different combinations according to subtypes. A key component of the Cascade complex in type I systems, responsible for foreign DNA cleavage, is Cas3 protein. In some subtypes of type I systems, Cas 3 is fused with Cas2 protein [14,22]. The type III system consists of 6 subtypes (III-A, III-B, III-C, III-D, III-E, and III-F); some of them include reverse transcriptase in the adaptation module. The cleavage of pre-crRNA in type III systems is mediated by Cas6 protein; however, most of the subtypes lack the cas 6 gene and use the Cas6 protein provided in trans by other CRISPR-cas loci. The effector complex in subtypes III-A, III-D, III-E, and III-F is a Csm complex composed of Csm/Cas proteins and crRNA. Subtypes III-B and III-C comprise the Cmr complex composed of $\mathrm{Cmr} / \mathrm{Cas}$ proteins and crRNA. Effector complexes of subtypes III-A, III-B, and III-C cleavage foreign RNA/DNA and, in subtypes III-D and III-E, are predicted to cleavage RNA, whereas in subtype III-F, effector complexes are predicted to cleavage DNA $[14,20,22]$. A type IV system contains 3 subtypes (IV-A, IV-B, and IV-C). These systems usually lack Cas proteins in the adaptation step and target cleavage of the foreign genomes. Processing of pre-crRNA is usually mediated by a unique Cas6 protein. It has been proposed that effector complexes of type IV systems contain Cas5, Cas7, and large subunit (Csf1) proteins. Recent studies suggest that type IV CRISPR-Cas systems could be highly diverged derivatives of types I or III systems [14,23].

Class 2 system consists of type II, type V, and type VI systems (Table 4). In contrast to class 1 , the effector complex of class 2 systems is a single, large, multidomain Cas protein bonded with crRNA. Type II system involves 3 subtypes (II-A, II-B, and II-C). Processing of pre-crRNA in type II systems is mediated by the coordinated action of three factors: RNase III (non-Cas protein), trans-activating CRISPR RNA (tracrRNA), and Cas9 protein. Alternative processing of pre-crRNA was discovered in subtype II-C systems. The single effector protein in type II systems is Cas9 with two nuclease domains responsible for cleavage of one strand of the target DNA [14,22]. A type $V$ system contains 10 subtypes (V-A, V-B, V-C, V-D, V-E, V-F, V-G, V-H, V-I, and V-K), with the Cas12 protein as a single effector complex. Processing of pre-crRNA in subtype V-A is performed by the effector complex, whereas in several type V subtypes, the processing is mediated by RNase III. Both strands of target DNA are cleaved by one domain of Cas12 protein. A type VI system involves 4 subtypes (VI-A, VI-B, VI-C, and VI-D). Single effector complexes in type VI systems are Cas13 proteins that differ from the other effector complexes in class 2 systems. The processing of pre-crRNA is performed by the effector complex. All effector complexes contain two higher eucaryotes and procaryote nucleotide-binding (HEPN) domains, which provide RNase activity. The HEPN domains of the Cas13 protein in type VI systems cleavage foreign RNA [14]. 
Table 3. Classification of class 1 CRISPR-Cas systems [14].

\begin{tabular}{|c|c|c|c|c|c|}
\hline Class & Type & Subtype & Variant & Native Target & Origin \\
\hline \multirow{18}{*}{1} & \multirow{9}{*}{ I } & I-A & & DNA & $\begin{array}{c}\text { Archaeoglobus fulgidus } \\
\text { (AF1859, AF1870-AF1879) }\end{array}$ \\
\hline & & I-B & & DNA & $\begin{array}{l}\text { Clostridium kluyveri } \\
\text { (CKL_2758-CKL_2751) }\end{array}$ \\
\hline & & $\mathrm{I}-\mathrm{C}$ & & DNA & $\begin{array}{l}\text { Bacillus halodurans } \\
\text { (BH0336-BH0342) }\end{array}$ \\
\hline & & I-D & & DNA & $\begin{array}{c}\text { Cyanothece sp. } 8802 \\
\text { (Cyan8802_0527-Cyan8802_0520) }\end{array}$ \\
\hline & & I-E & & DNA & $\begin{array}{l}\text { Escherichia coli } \mathrm{K} 12 \\
\quad(\mathrm{ygcB}-\mathrm{ygbF})\end{array}$ \\
\hline & & \multirow{3}{*}{ I-F } & I-F1 & DNA & $\begin{array}{l}\text { Yersinia pseudo-tuberculosis } \\
\text { (YPK_1644-YPK-1649) }\end{array}$ \\
\hline & & & I-F2 & DNA & $\begin{array}{l}\text { Shewanella putrefaciens CN-32 } \\
\text { (Sputcn32_1819-Sputcn32_1823) }\end{array}$ \\
\hline & & & \multirow[t]{2}{*}{ I-F3 } & & $\begin{array}{c}\text { Vibrio crassostreae J5 } 20 \\
\text { (VCR20J5_310088-VCR20J5_310108) }\end{array}$ \\
\hline & & I-G & & DNA & $\begin{array}{c}\text { Geobacter sulfurreducens } \\
\text { (GSU0051-GSU0054, GSU0057-GSU0058) }\end{array}$ \\
\hline & \multirow{6}{*}{ III } & III-A & & DNA + RNA & $\begin{array}{l}\text { Staphylococcus epidermidis } \\
\text { (SERP2463-SERP2455) }\end{array}$ \\
\hline & & III-B & & $\mathrm{DNA}+\mathrm{RNA}$ & $\begin{array}{l}\text { Pyrococcus furiosus } \\
\text { (PF1131-PF1124) }\end{array}$ \\
\hline & & III-C & & DNA + RNA & $\begin{array}{c}\text { Methanothermobacter thermautotrophicus } \\
\text { (MTH328-MTH323) }\end{array}$ \\
\hline & & III-D & & RNA? & $\begin{array}{l}\text { Synechocystis sp. } 6803 \\
\text { (sll7067-sll7063) }\end{array}$ \\
\hline & & III-E & & RNA? & $\begin{array}{l}\text { Candidatus Scalidua brodae } \\
\text { (SCABRO_02601, SCABRO_02597, } \\
\text { SCABRO_02593, SCABRO_02595) }\end{array}$ \\
\hline & & III-F & & DNA? & $\begin{array}{l}\text { Thermotoga lettingae TMO } \\
\text { (Tlet_0097-Tlet_0100) }\end{array}$ \\
\hline & \multirow{3}{*}{ IV } & IV-A & & & $\begin{array}{l}\text { Thioalkalivibrio sp. K90mix } \\
\text { (TK90_2699-TK90_2703) }\end{array}$ \\
\hline & & IV-B & & & $\begin{array}{c}\text { Rhodococcus jostii RHA1 } \\
\text { (RHA1_ro10069-RHA_ro10072) }\end{array}$ \\
\hline & & IV-C & & DNA? & $\begin{array}{c}\text { Thermoflexia bacterium } \\
\text { (D6793_05715-D6793_05700) }\end{array}$ \\
\hline
\end{tabular}


Table 4. Classification of class 2 CRISPR-Cas systems. An asterisk represents a variant that was formerly classified as variant I-U3 [14].

\begin{tabular}{|c|c|c|c|c|c|}
\hline Class & Type & Subtype & Variant & Native Target & Origin \\
\hline \multirow{26}{*}{2} & \multirow{4}{*}{ II } & II-A & & DNA & $\begin{array}{l}\text { Streptococcus thermophilus } \\
\text { (str0657-str0660) }\end{array}$ \\
\hline & & II-B & & DNA & $\begin{array}{l}\text { Legionella pneumophila str. Paris } \\
\text { (lpp0160-lpp0163) }\end{array}$ \\
\hline & & \multirow{2}{*}{ II-C } & II-C1 & DNA & $\begin{array}{l}\text { Neisseria lactamica 020-06 } \\
\text { (NLA_17660-NLA_17680) }\end{array}$ \\
\hline & & & II-C2 & DNA & $\begin{array}{l}\text { Micrarchaeum acidiphilum ARMAN-1 } \\
\text { (BK997_03320-BK997_03335) }\end{array}$ \\
\hline & \multirow{17}{*}{ V } & V-A & & DNA & $\begin{array}{l}\text { Francisella cf. Novicida Fx1 } \\
\text { (FNFX1_1431-FNFX1_1428) }\end{array}$ \\
\hline & & \multirow{2}{*}{ V-B } & V-B1 & DNA & $\begin{array}{l}\text { Alicyclobacillus acidoterrestris } \\
\text { (N007_06525-N007_06535) }\end{array}$ \\
\hline & & & V-B2 & DNA & $\begin{array}{l}\text { Planctomycetes bacterium RGB_13_46_10 } \\
\text { (A2167_01675-A2167_01685) }\end{array}$ \\
\hline & & $\mathrm{V}-\mathrm{C}$ & & DNA & $\begin{array}{c}\text { Oleiphilus sp. } \\
\text { (A3715_16885-A3715_16890) }\end{array}$ \\
\hline & & V-D & & DNA & $\begin{array}{c}\text { Bacterium CG09_39_24 } \\
\text { (BK003_02070-BK003_02075) }\end{array}$ \\
\hline & & V-E & & DNA & $\begin{array}{c}\text { Deltaproteobacteria bacterium } \\
\text { (A2Z89_08250-A2Z89_08265) }\end{array}$ \\
\hline & & \multirow{7}{*}{ V-F } & V-F1 & DNA & $\begin{array}{c}\text { Uncultured archaeon } \\
\text { (NDOCEIEL_00008-NDOCEIEL_00011) }\end{array}$ \\
\hline & & & V-F1* & DNA & $\begin{array}{l}\text { Bacillus thuringiensis HD-771 } \\
\text { (BTG_31928) }\end{array}$ \\
\hline & & & V-F2 & DNA & $\begin{array}{c}\text { Uncultured archaeon } \\
\text { (ICDLJNLD_00049-ICDLJNLD_00052) }\end{array}$ \\
\hline & & & V-F3 & & $\begin{array}{l}\text { Candidatus Micrarchaeota archaeon } \\
\text { (COU37_03050-COU37_03065) }\end{array}$ \\
\hline & & & V-U1 & & $\begin{array}{l}\text { Gordonia otitidis } \\
\text { (GOOTI_RS19525) }\end{array}$ \\
\hline & & & V-U2 & & $\begin{array}{c}\text { Cyanothece sp. PCC } 8801 \\
\text { (PCC8801_4127) }\end{array}$ \\
\hline & & & V-U4 & & $\begin{array}{l}\text { Rothia dentrocariosa M567 } \\
\text { (HMPREF0734_01291) }\end{array}$ \\
\hline & & V-G & & RNA & $\begin{array}{c}\text { Hot springs metagenome } \\
\text { FLYL01000025.1 (182949-185252) }\end{array}$ \\
\hline & & $\mathrm{V}-\mathrm{H}$ & & & $\begin{array}{l}\text { Hypersaline lake sediment metagenome (JGI) } \\
\text { (Ga0180438_100006283) }\end{array}$ \\
\hline & & V-I & & DNA & $\begin{array}{l}\text { Freshwater metagenome (JGI) } \\
\left(\mathrm{Ga0208225 \_ 100001036)}\right.\end{array}$ \\
\hline & & $\mathrm{V}-\mathrm{K}$ & & & $\begin{array}{c}\text { Cyanothece sp. PCC 8801 } \\
\text { (PCC8801_2993-PCC8801_2997) }\end{array}$ \\
\hline & \multirow{5}{*}{ VI } & VI-A & & RNA & $\begin{array}{l}\text { Leptotrichia shahii } \\
\text { (B031_RS0110445) }\end{array}$ \\
\hline & & \multirow{2}{*}{ VI-B } & VI-B1 & RNA & $\begin{array}{c}\text { Prevotella buccae } \\
\text { (HMPREF6485_RS00335-HMPREF6483_RS00340) }\end{array}$ \\
\hline & & & VI-B2 & RNA & $\begin{array}{c}\text { Bergeyella zoohelcum } \\
\text { (HMPREF9699_02005-HMPREF9699_02006) }\end{array}$ \\
\hline & & VI-C & & RNA? & $\begin{array}{l}\text { Fusobacterium perfoetens } \\
\text { (T364_RS0105110) }\end{array}$ \\
\hline & & VI-D & & RNA & $\begin{array}{l}\text { Ruminococcus bicirculans } \\
\text { (RBI_RS12820) }\end{array}$ \\
\hline
\end{tabular}




\subsection{Structure and Function of Effector Complexes}

\subsubsection{Effector Complexes of Class 1}

The Cascade complex is a multiprotein complex for interference in type I systems (Figure 4). Among all subtypes in type I systems, subtype I-E of Escherichia coli is the most thoroughly characterized. Moreover, subtype I-E contains a full complement of subunits that are present in another type I systems; therefore, it is a unique model of the Cascade complex. The formula of the Cascade type I-E CRISPR-Cas system can be described as follows: (Cas5e $)_{1}-(\text { Cas6e })_{1}-(\text { Cas7e })_{6}-(\text { Cas8e })_{1}-(\text { Cas11e })_{2}$ with a molecular weight of 450 $\mathrm{kDa}$. The structure of the Cascade I-E type consists of 6 Cas7e proteins, which form a helical backbone with integrated crRNA that is capped with the Cas5e protein. Furthermore, two Cas11e proteins termed "small subunits" interact with the Cas7e backbone. The protein Cas8e also termed a "large subunit", interacts with the Cas5e, Cas6e, and Cas7e proteins and forms the tail of the Cascade complex. The Cas8e protein recognizes the PAM sequence in the target DNA and is responsible for the initial local unwinding of target DNA. Further conformational changes induce the participation of Cas3 nuclease for the final cleavage of the target DNA. Although the general composition and Cas3 nuclease involvement among the Cascade complexes of type I systems are similar, several subtypes manifest significant differences. Notably, subtype I-C expresses a minimal architecture of the Cascade complex. The backbone in the subtype I-F Cascade complex contains an unusual helical pitch [20,24].
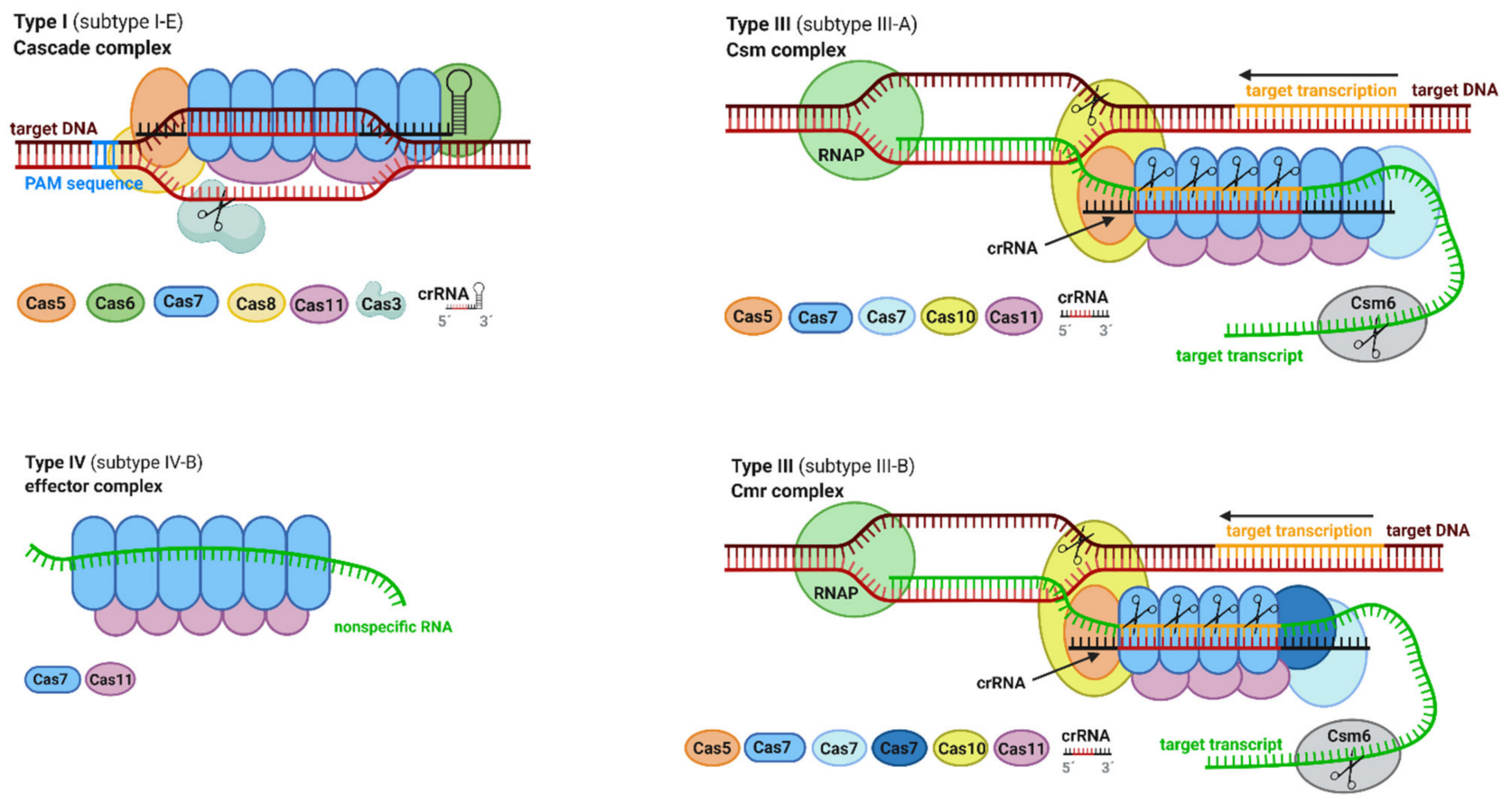

Figure 4. Selected multiprotein effector complexes of CRISPR class 1 systems. Figure was created with BioRender.com (accessed on 15 February 2021).

Csm (in subtype III-A) and Cmr (in subtype III-B) complexes are multiprotein interference complexes similar in structure and protein composition to the Cascade complex of type I systems (Figure 4). These complexes are best characterized among the type III systems. In contrast to the Cascade complex, the Csm and Cmr complexes cleave both invading RNA and DNA. The backbones of Csm and $\mathrm{Cmr}$ complex structures consist of Cas7-family proteins fused with crRNA, which is capped with the Cas5 protein. Cas11 represents a small subunit, while the large subunit is a Cas10 protein. Cleavage of the target genome begins by binding the type III effector complex to a nascent target transcript in a crRNA-dependent manner. The single-stranded RNA (ssRNA) is cleaved at every 
sixth nucleotide by Cas7 subunits, whereas DNA cleavage is mediated by Cas10 protein and strictly requires transcription of the target in both systems [10,24].

The first effector complex of type IV systems was described in 2020 by Zhou et al. in subtype IV-B. The structure of the subtype IV-B CRISPR effector complex involves a helical backbone formed by 7 Cas7-like proteins, bundled with 5 Cas 11 proteins (Figure 4). Interestingly, the Cas7 protein of subtype IV-B exhibits significant similarities to Cas7 of the Csm complex in subtype III-A. The RNase activity of the Cas7 protein in subtype III-A is also proposed for Cas7 of subtypes IV-B. In addition, the structure of the Csm complex with crRNA strongly resembles the structure of the IV-B effector complex with nonspecific RNA. The ability of the subtype IV-B CRISPR effector complex to bind nonspecific RNA remains unclear. Moreover, in contrast to the Csm complex, one of the catalytic residues (Asp42) of the Cas7 subtype IV-B complex is in a noncompatible position for target RNA cleavage. The study reported by Zhou et al. reveals that type IV systems evolved from ancestors of type III-like systems [25].

\subsubsection{Effector Complexes of Class 2}

The CRISPR-Cas9 system is utilized in the type II system and provides its function via a single effector complex comprising a Cas9 protein, crRNA, and tracrRNA (Figure 5). The target DNA interacts with two different areas of the effector complex. One bond is mediated by a guide spacer sequence (18-24 nt) of crRNA with a target DNA complementary sequence. The PAM interacting (PI) domain of the effector complex binds to its recognition site upstream of the PAM sequence. Double-stranded breaks of the target DNA perform two domains of the complex. The HNH (histidine-asparagine-histidine) nuclease domain cleaves the target strand, whereas the RuvC nuclease domain cleaves the nontarget strand of foreign DNA [26].
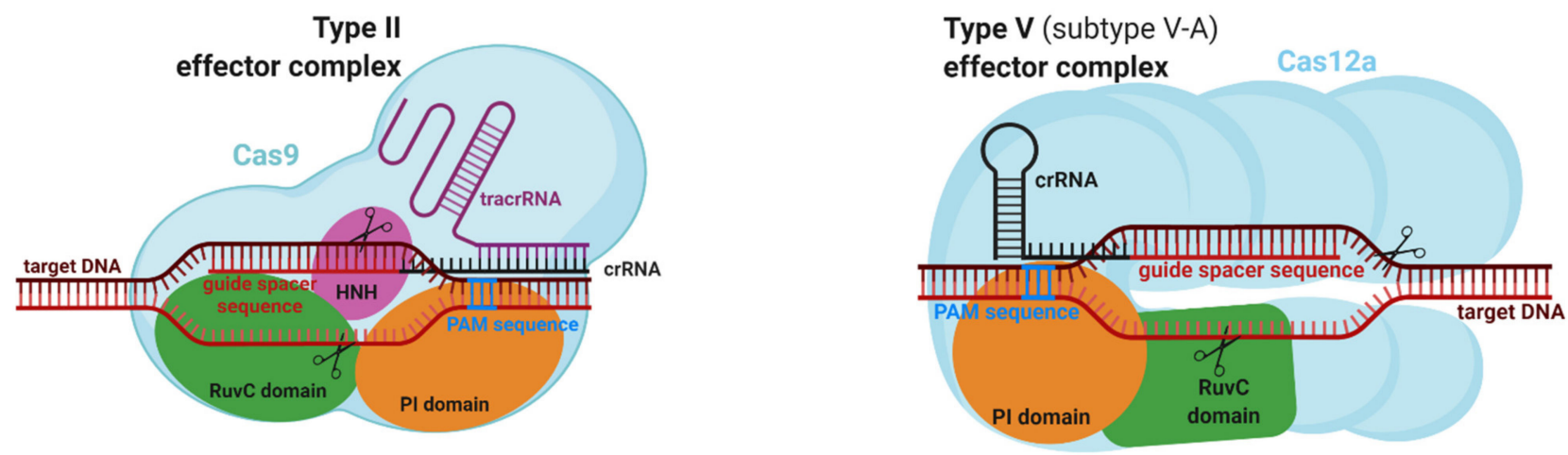

Type VI (subtype VI-A)

effector complex

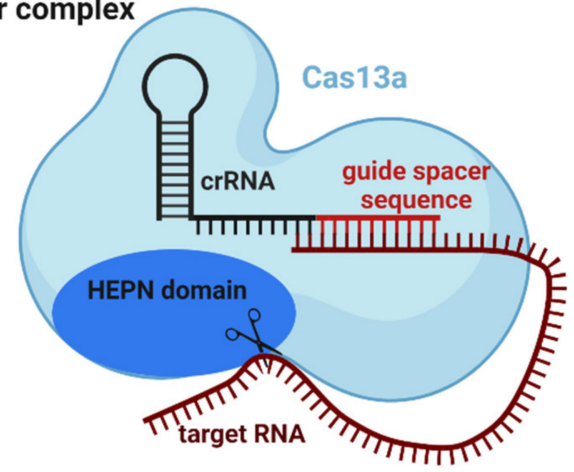

Figure 5. Selected single effector complexes of class 2. The figure was created with BioRender.com, accessed on 15 February 2021. 
The CRISPR-Cas12a system in subtype V-A systems performs its functions via a single effector complex, which is composed of the Cas12a protein and crRNA (Figure 5). Two areas of the effector complex interact with target DNA. The PI domain of the effector complex binds to its recognition site downstream of the PAM sequence. The second interaction is between the guide space sequence (23-25 nt) of the crRNA and a complementary sequence of the target DNA. Double-stranded breaks in invading DNA are mediated by two domains. The Nuc domain cleaves the target strand and the RuvC domain nontarget strand of target DNA [26].

The CRISPR-Cas13a system is utilized in subtypes VI-A, and its function is provided via a single effector complex, which contains Cas13a protein and crRNA (Figure 5). The guide spacer sequence (22-30 nt) of crRNA recognizes complementary sequences in foreign RNA. The CRISPR-Cas13a system does not require a PAM sequence, but some subtypes require a single base-specific protospacer flanking site (PFS) sequence. However, there are also subtypes of CRISPR-Cas13 systems that do not require specific PFSs. In contrast to Cas9 or Cas12, there are no HNH and RuvC domains in the Cas13 protein. Therefore, DNA is not a target molecule of Cas13. The cleavage of target RNA is mediated by the HEPN domains of the complex [26].

\section{Applications of CRISPR-Cas Systems}

The development of the RNA-programmable site-specific CRISPR-Cas9 system in gene editing methods published in the Science journal [27] inspired countless potential applications and won many internationally acclaimed awards including a Nobel Prize. The Royal Swedish Academy of Science decided to award the Nobel Prize in Chemistry 2020 to Emmanuelle Charpentier and Jennifer A. Doudna "for the development of a method for genome editing".

Both classes of CRISPR systems have a significant potential for genome editing; however effector complexes of class 2 systems are more simplified and, thus, they are preferable in genetic engineering. Genome editing via CRISPR class 2 systems utilizes an artificial single-guide RNA (sgRNA) that consists of tracrRNA, crRNA, and an artificial RNA linker [21]. In contrast to artificial sgRNAs, a natural guide RNA (gRNA) in type II systems, also termed a crRNA-tracrRNA complex consists only of tracrRNA and crRNA without the linker (Figure 6A). In addition, a modified sgRNA, which carries both sequences-one to generate double-stranded breaks and the second for a homology-directed repair-is termed a chimeric single-guide RNA (cgRNA). Further modifications were carried out on the Cas9 active sites. These modifications in the CRISPR-Cas9 system improved some mechanisms compared to the wild-type system, e.g., in DNA targeting or the introduction of single-stranded breaks (SSB) in DNA instead of double-stranded breaks (DSB) [21].

The CRISPR-mediated genome editing introduces DBSs close to the PAM sequence (Figure 6B). DBSs in eukaryotes are repaired by non-homologous end joining (NHEJ) or homology-directed repair (HDR) pathways. The NHEJ is an error-prone repair mechanism in which insertions and deletions (indels) occur at the DSB junctions. The HDR pathway requires the presence of a homologous DNA template but repairs DSB with high precision. HDR allows for inserting novel genes (knock-in) or "knockout" existing genes. The homologous sequences can be provided exogenously and utilized to target genome editing $[21,28]$.

Base editing belongs to genome editing methods, which can generate precise point mutations in DNA or RNA without generating DSBs. The base editing method requires a DNA donor template or relies on HDR. The DNA base editors are divided into two classes: cytosine base editors (CBEs) and adenine base editors (ABEs). The CBEs convert a C-G base pair into a T-A pair, whereas ABEs convert the A-T pair into a $\mathrm{G}-\mathrm{C}$ base pair. Both base editors thus can provide all four possible conversions $(C \rightarrow T, A \rightarrow G, T \rightarrow C$, and $\mathrm{G} \rightarrow \mathrm{A})[21,29]$. 
A:

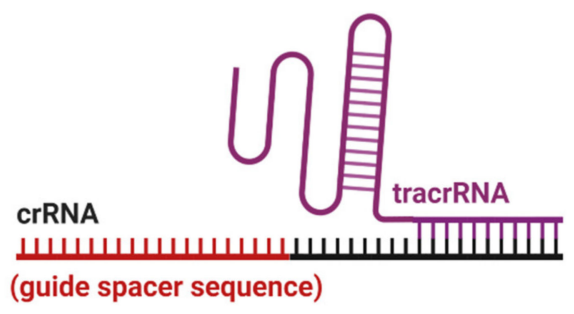

crRNA:tracrRNA complex

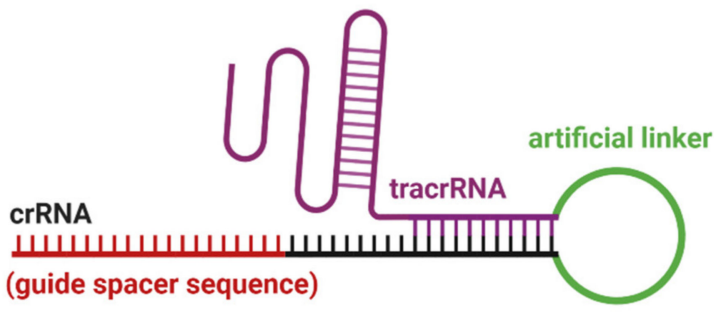

sgRNA

B:

\section{DOODOODOO}
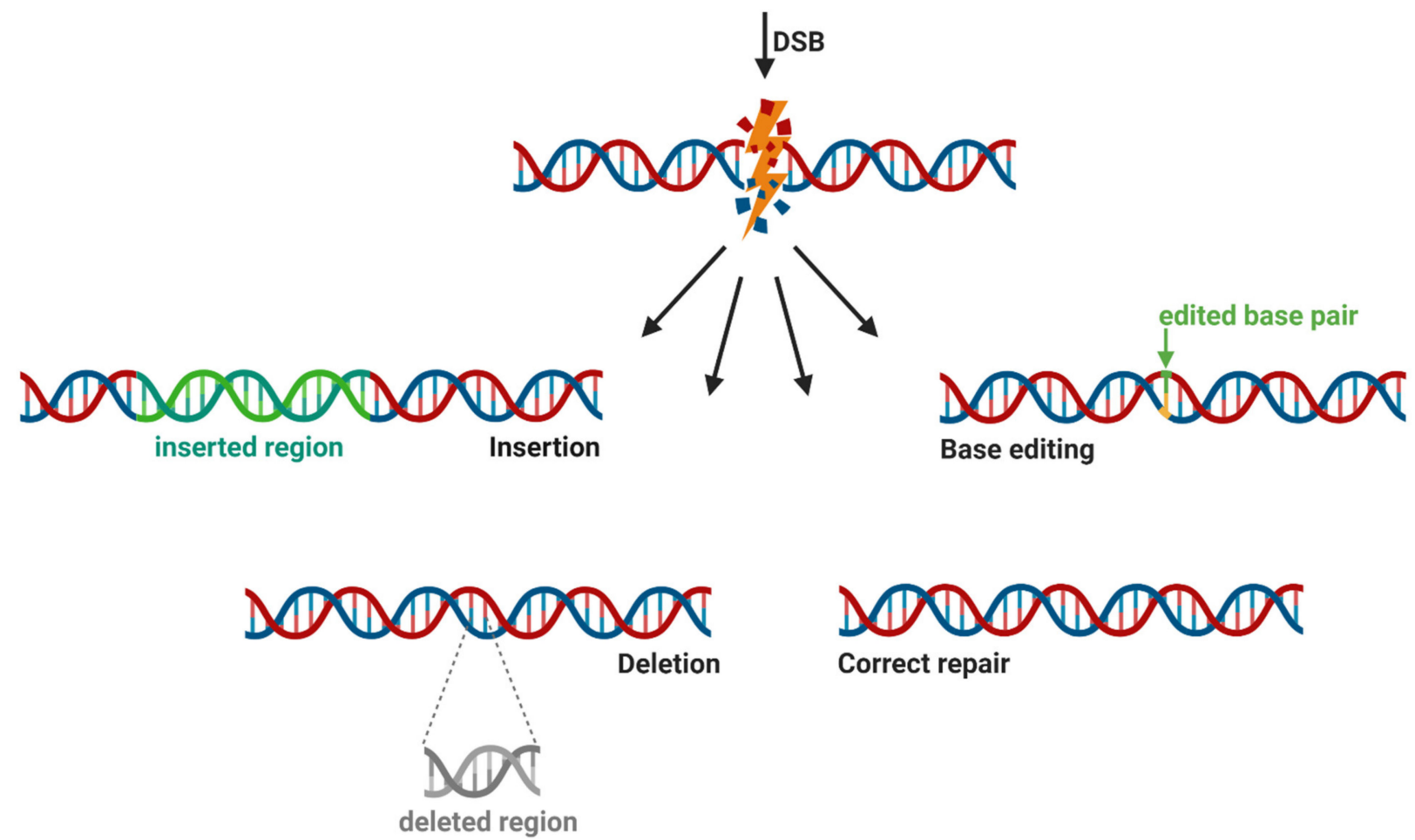

DOODOODOO

Correct repair

deleted region

Figure 6. (A) General structure of the CRISPR RNA (crRNA)-trans-activating CRISPR RNA (tracrRNA) complex and artificial single-guide RNA (sgRNA). (B) CRISPR-Cas-assisted gene editing. The figure was created with BioRender.com (accessed on 15 February 2021).

\subsection{In Plant Biotechnology}

According to a report published in the Global Hunger Index, 2019, the increasing climate change impacts food systems adversely, weather-related disasters reduce crop yield, and excess carbon dioxide generation decreases the nutritional value of crops. To combat food scarcity, agricultural productions must be enhanced by the combination of traditional plant breeding (whole-genome editing) and innovative techniques such as molecular plant breeding (targeted genome editing) and specific gene editing. Targeted genome editing has increased productivity: increasing the grain size, weight, number, protein content, tiller spread, and tiller number in rice and wheat [30-32] and quality of crops in rice [30,31] and corn [33]. Modified crops using the CRISPR-Cas system were targeted to reduce the levels of toxic steroidal glycoalkaloids, enhancing the color and shelf-life of fruits and vegetables and making them commercially attractive. The modifications further involved an increase 
in amylose, starch, good fats such as oleic acid levels; fragrance improvements; a decrease in gluten proteins and unsaturated fatty acids content; etc. [34-37].

\subsubsection{Resistivity to Stress}

Stress significantly reduces the productivity of agricultural crops. Stress in plants can be divided into two categories: abiotic stress is caused by different factors including drought, floods, temperature extremes, salinity, heavy metals, radiation, etc. In contrast, biotic stress involves attacks by various pathogens, e.g., viruses, bacteria, fungi, herbivores, and others. Crops such as rice, tomato, cucumber, grapefruits, etc. have been modified by inducing mutation to protect from abiotic [38,39] and biotic stresses [40]. The site-specific genomic mutation was performed earlier by DNA-binding endonucleases such as zinc finger nuclease (ZFN) and transcription activator-like effector nucleases (TALEN) but has limitations [41]. For the first time, the CRISPR-Cas system was used for genome editing in rice (Oryza sativa), wheat (Triticum aestivum), Nicotiana benthamiana, and Arabidopsis thaliana [42].

A customized sgRNA-Cas9 system has been widely used by Shan et al. in genome modification in rice (Oryza sativa) and wheat (Triticum aestivum); the first plants showed the ease of genome editing [38]. Cas12a (formerly termed Cpf1) is advantageous over Cas9 in plant genome editing because sgRNA-Cas12a requires shorter guiding nucleotides, creates larger deletions at the target sites, and helps in NHEJ mediated donor DNA insertion [43].

Before genome editing, CRISPR-Cas reagents, i.e., DNA, sgRNA, and Cas proteins, must be delivered to the plants. The delivery is performed by protoplast transfection or Agrobacterium-mediated or biolistic transformations. Agrobacterium tumefaciens-assisted sgRNA-Cas9 targeting of plant herbicide resistance gene BEL (Bentazon Sensitive Lethal) in rice has been demonstrated to obtain transgenic plants sensitive to bentazon, a herbicide with a mutagenesis efficiency of $2-16 \%$ [44]. Geminiviruses also serve as a good vector for transfer and expression of the sgRNA-Cas9 construct [45]. Xiang Ji and collaborators mutated genomic sequences and restricted viral load in Nicotiana benthamiana using beet severe curly top virus (BSCTV), one Geminivirus [45]. The sequence-specific interference of Geminiviruses by CRISPR-Cas tools boosting the immunity of the plants has been reported [46]. This virus-based editing, termed virus genome editing (VIGE), has been used to target the genome and to create mutations but fails to transmit these mutations to the next generations [45]. However, in Arabidopsis, Zhengyan Fenga and coworkers demonstrated the mutation and heritability of five endogenous target genes-brassinosteroid insensitive 1 (bri1), jasmonate-zim-domain protein 1 (jaz1), gibberellic acid insensitive (gai), magnesium chelatase subunit $i(c h l i)$, and transparent testa 4 ( $t+4)$-in addition to the apetala1 (ap1) gene [47]. Similarly, the CRISPR-Cas tools can be used for regulating the genes responsible for the epigenetic modification, methylation, and/or demethylation, inducing and repressing the genes simultaneously [48].

CRISPR-Cas13a efficiently targets RNA viruses, mostly plant viruses. Aman et al. [49] utilized LshCas13a (a Cas13a variant from Leptotrichia shahii) for targeting Turnip mosaic virus (TuMV), a Potyvirus, in Nicotiana benthamiana, an Agrobacterium containing green fluorescent protein (GFP) expressing TuMV with LshCas13a tagged with C-terminal nuclear localization sequence (NLS) and various crRNAs targeting different parts on the viral genomes. After seven days of infiltration, two out of the four crRNA showed a 50\% reduction in GFP expression. Cas13a was also used for precise RNA modifications and visualization. Dead Cas13a was formed by a point mutation at the HEPN domain responsible for RNA targeting. Abudayyeh et al. [50] used dLwaCas13a (a dead Cas13a variant from Leptotrichia wadei) fused with fluorescent proteins to visualize specific transcripts in live cells.

Hybrid breeding is another method that increases crop productivity including improvements in hybrid wheat seed production. Indeed, hybrid crops used today are effective high-yield varieties; however, the production of hybrid seeds requires sterilization to prevent self-pollination. Similarly, for precision plant breeding, knockout, a process 
of replacing the undesired gene with the desired gene, is performed [42]. CRISPR-Cas has been employed to produce thermosensitive male-sterile TMS5 lines in rice [51] and maize [52], Ms45 in wheat, etc. [53]. The male-sterile lines produced a high-quality hybrid variety. Similarly, haploid rice has been obtained by knockout of the OsMATL gene [54]. Furthermore, the CBE has been used to confer herbicide resistance in rice [55], Arabidopsis [56], and watermelon [57]. Further CRISPR-Cas genome editing studies in plants are summarized in Table 5 .

Table 5. The application of CRISPR-Cas in plant biotechnology. Abbreviations: CBSD, Cassava brown streak disease; PUFA, polyunsaturated fatty acids.

\begin{tabular}{|c|c|c|c|c|}
\hline Crops & Target Genes & Editing Process & Results & References \\
\hline \multicolumn{5}{|c|}{ Biotic Factors } \\
\hline Apple & DIPM1, DIPM2, DIPM4 & Gene knockout & Resistance to fire blight disease & {$[58]$} \\
\hline Arabidopsis thaliana & $\begin{array}{l}\text { Non-coding/coding region } \\
\text { of viral genome, eIF(iso)4E }\end{array}$ & Gene knockout & Virus resistance & [59] \\
\hline Banana & banana streak virus genes & Gene inactivation & Virus resistant & {$[60]$} \\
\hline Cassava & $\begin{array}{l}\text { eIF4E isoforms } n C B P-1 \text {, } \\
n C B P-2\end{array}$ & Gene knockout & Partial resistance to CBSD & {$[61]$} \\
\hline Cassava & EPSPS & $\begin{array}{l}\text { Gene insertion and } \\
\text { replacement }\end{array}$ & Herbicide resistant & {$[62]$} \\
\hline Citrus & PthA4, CsLOB1 & Gene knockout & Resistance to citrus canker & {$[63]$} \\
\hline Citrus & CsLOB1 & Gene knockout & Resistance to citrus canker & {$[64]$} \\
\hline Cocoa & TcNPR3 & Gene knockout & $\begin{array}{l}\text { Increased resistance to } \\
\text { Phytophthora tropicalis }\end{array}$ & {$[65]$} \\
\hline Cotton & clcud & Gene disruption & Leaf curl disease resistant & {$[66]$} \\
\hline Cotton & Gh14-3-3d & Gene knockout & $\begin{array}{c}\text { Resistance to } \\
\text { Verticillium dahlia }\end{array}$ & {$[67]$} \\
\hline Cucumber & eIF4E & Gene knockout & Broad virus resistant & {$[68]$} \\
\hline Flax & EPSPS & $\begin{array}{l}\text { Gene insertion and } \\
\text { replacement }\end{array}$ & Herbicide resistant & [69] \\
\hline Grape vine & VvWRKY52 & Gene knockout & Resistance to Botrytis cinerea & {$[70]$} \\
\hline Grape vine & MLO7 & Gene knockout & Resistance to powdery mildew & {$[58]$} \\
\hline Potato & $A L S$ & $\begin{array}{l}\text { Gene insertion and } \\
\text { replacement }\end{array}$ & Herbicide resistant & {$[71]$} \\
\hline Potato & Coilin & Gene knockout & $\begin{array}{l}\text { Increased resistance } \\
\text { to potato virus } Y\end{array}$ & {$[72]$} \\
\hline Rice & $\begin{array}{l}\text { OsERF922, OsSEC } 3 A, \\
\text { OsSWEET13 }\end{array}$ & Gene mutations & $\begin{array}{l}\text { Resistant to blast and } \\
\text { bacterial blight }\end{array}$ & [73] \\
\hline Rice & CYP71A1 & Gene knockout & $\begin{array}{l}\text { Broad-spectrum resistance to } \\
\text { insect pests }\end{array}$ & {$[40]$} \\
\hline Rice & eIF4G & Gene mutation & $\begin{array}{l}\text { Resistance to rice tungro } \\
\text { spherical virus }\end{array}$ & {$[74]$} \\
\hline Rice & $A L S$ & $\begin{array}{l}\text { Gene insertion and } \\
\text { replacement }\end{array}$ & Herbicide resistant & {$[42]$} \\
\hline Rice & EPSPS & $\begin{array}{l}\text { Gene insertion and } \\
\text { replacement }\end{array}$ & Herbicide resistant & {$[75]$} \\
\hline Rice & C287T, ALS & Multiplex genome editing & Herbicide resistance & [55] \\
\hline Rice & UVb1-1 & Multiplex genome editing & Resistance against false smut & [76] \\
\hline Rice & $A L S$ & Base editing & Herbicide resistant & {$[55]$} \\
\hline Soybean & $A L S$ & $\begin{array}{l}\text { Gene insertion and } \\
\text { replacement }\end{array}$ & Herbicide resistant & [77] \\
\hline Tobacco & AGO2 & Gene knockout & Virus resistance & {$[78]$} \\
\hline Tomato & SlMLO1 & Gene deletion & Powdery mildew resistant & [79] \\
\hline Tomato & SlJAZ2 & Gene truncation & Bacterial speck resistant & [80] \\
\hline Watermelon & ALS & Base editing & Herbicide resistant & [57] \\
\hline Wheat & EDR1 & Gene knockout & Resistant to powdery mildew & [81] \\
\hline Wheat & $\begin{array}{c}\text { TaMLO-A1, TaMLO-B1, } \\
\text { TaMLO-D1 }\end{array}$ & Gene knockout & Resistant to powdery mildew & {$[82]$} \\
\hline
\end{tabular}


Table 5. Cont.

\begin{tabular}{|c|c|c|c|c|}
\hline Crops & Target Genes & Editing Process & Results & References \\
\hline \multicolumn{5}{|c|}{ Abiotic Factors } \\
\hline Arabidopsis thaliana & UGT79B2 and UGT79B3 & Gene knockout & $\begin{array}{l}\text { Cold, salt, and drought } \\
\text { resistance }\end{array}$ & [83] \\
\hline Barley & $\begin{array}{c}\text { ENGase, HvPM19, } \\
\text { BolC.GA4.a }\end{array}$ & Gene knockout & $\begin{array}{l}\text { Grain number increase and } \\
\text { dormancy control }\end{array}$ & {$[84]$} \\
\hline $\begin{array}{c}\text { False flax } \\
\text { (Camelina sativa) }\end{array}$ & FAD2, CsDGAT1, CsPDAT1 & $\begin{array}{c}\text { Multiplex genome editing } \\
\text { using CRISPR }\end{array}$ & $\begin{array}{l}\text { Increased oleic acid and } \\
\text { decreased PUFA }\end{array}$ & {$[34,36]$} \\
\hline Grape vine & $I d n D H$ & $\begin{array}{l}\text { Gene insertion and } \\
\text { replacement }\end{array}$ & $\begin{array}{c}\text { Failure of tartaric acid } \\
\text { biosynthesis or accumulation }\end{array}$ & [85] \\
\hline Lotus & SNF, SYMRK, LjLb1, LjLb2 & Gene knockout & Increased nitrogen accumulation & [86] \\
\hline Maize & $W x 1$ & Gene knockout & Increased amylose & [52] \\
\hline Maize & TMS5 & Gene knockout & Male sterile lines & [52] \\
\hline Maize & ARGOS8 & $\begin{array}{l}\text { Gene insertion and } \\
\text { replacement }\end{array}$ & Drought tolerance & [52] \\
\hline Maize & Dek42 & Gene knockout & $\begin{array}{c}\text { Regulation of kernel } \\
\text { development }\end{array}$ & [87] \\
\hline Mushroom & PPO & Gene knockout & Browning-resistant mushroom & [88] \\
\hline Opium poppy & $4^{\prime} \mathrm{OMT} 2$ & Gene knockout & Biomolecule synthesis & [89] \\
\hline Orchids & $\begin{array}{c}\mathrm{C} 3 H, \mathrm{C} 4 \mathrm{H}, 4 \mathrm{CL}, \mathrm{CCR}, \\
\text { and } I R X\end{array}$ & Gene knockout & $\begin{array}{l}\text { Increased lignocellulose } \\
\text { biosynthesis }\end{array}$ & {$[90]$} \\
\hline Orchids & PDS & $\begin{array}{l}\text { Gene insertion and } \\
\text { replacement }\end{array}$ & Increasing quality and quantity & [91] \\
\hline Potato & StGBSS & Gene knockout & Amylose synthesis & [92] \\
\hline Potato & StMYB44 & Gene knockout & Phosphate stress response & [93] \\
\hline Potato & $A L S$ & Gene knockout & Chlorsulfuron resistance & [94] \\
\hline Rice & Gn1a, DEP1, GS3 & Gene knockout & $\begin{array}{l}\text { Enhanced grain size and number } \\
\text { and dense erect panicles }\end{array}$ & {$[95]$} \\
\hline Rice & OsGn1a & Gene knockout & Grain number & {$[30,31]$} \\
\hline Rice & OsGS3 & Gene knockout & Grain size & {$[30,31]$} \\
\hline Rice & $\begin{array}{c}\text { TaGW2, OsGW5, OsGLW2, } \\
\text { or TaGASR7 }\end{array}$ & Gene knockout & Grain weight & {$[30,31]$} \\
\hline Rice & OsDEP1, TaDEP1 & Gene knockout & Panicle size & {$[30,31]$} \\
\hline Rice & LAZY1 & Gene knockout & Tiller spreading & {$[30,31]$} \\
\hline Rice & OsAAP3 & Gene knockout & Increased tiller number & {$[30,31]$} \\
\hline Rice & GW2, GW5, and TGW6 & Gene knockout & Gain weight improvement & [96] \\
\hline Rice & $\begin{array}{c}\text { OsPDS, OsMPK2, } \\
\text { OsBADH2 } \\
\text { OsDERF1, OsPMS3, }\end{array}$ & Gene knockout, Indels & Edited abiotic stress tolerance & {$[38]$} \\
\hline Rice & $\begin{array}{c}\text { OsEPSPS, OsMSH1, } \\
\text { OsMYB5 }\end{array}$ & Gene knockout & Edited drought tolerance & [97] \\
\hline Rice & OsHAK-1 & Gene knockout & $\begin{array}{l}\text { Strongly reduced content } \\
\text { of }{ }^{137} \mathrm{Cs}^{+}\end{array}$ & [98] \\
\hline Rice & OsPRX2 & Gene knockout & $\begin{array}{l}\text { Serious defects in leaves, stomal } \\
\text { opening under } \mathrm{K}^{+} \text {-deficient } \\
\text { conditions }\end{array}$ & [99] \\
\hline Rice & OsAnn3 & Gene knockout & Decreased cold tolerance & [100] \\
\hline Rice & SBEIIb & Gene knockout & Higher amylose content & {$[37]$} \\
\hline Rice & TMS5 & Gene knockout & $\begin{array}{l}\text { Thermosensitive male } \\
\text { sterile lines }\end{array}$ & {$[51]$} \\
\hline Rice & $\operatorname{cs} a$ & Gene knockout & Photosensitive male sterile lines & [95] \\
\hline Rice & OsMATL & Gene knockout & Haploid seed formation & [54] \\
\hline Rice & ACCase gene & Base editing & Haloxyfop-R-methyl resistant & [101] \\
\hline Rubber & TK 1-FFT & Gene knockout & Rubber biosynthesis & [102] \\
\hline Soybean & GmSPL9a, $b, c$ & $\begin{array}{l}\text { Gene insertion and } \\
\text { replacement }\end{array}$ & Improved yield & [103] \\
\hline Tomato & SlAGL6 & Gene knockout & $\begin{array}{l}\text { Parthenocarpic fruit production } \\
\text { under heat stress conditions }\end{array}$ & [39] \\
\hline
\end{tabular}


Table 5. Cont.

\begin{tabular}{|c|c|c|c|c|}
\hline Crops & Target Genes & Editing Process & Results & References \\
\hline Tomato & SIIAA9 & Gene knockout & $\begin{array}{c}\text { Production of parthenocarpic } \\
\text { plants }\end{array}$ & [104] \\
\hline Tomato & RIN & Gene knockout & Improved shelf life & [105] \\
\hline Tomato & $A P 2 a, N O R, T D R 4, M B P 7$ & Gene knockout & Delayed fruit ripening & [106] \\
\hline Tomato & SlAGO7 & Gene knockout & Increased growth & [107] \\
\hline Tomato & SINPR1 & Gene knockout & $\begin{array}{l}\text { Role of SINPR1 in drought } \\
\text { resistance }\end{array}$ & [108] \\
\hline Wheat & GW2 & Base editing & $\begin{array}{l}\text { Increased grain and protein } \\
\text { content }\end{array}$ & {$[32]$} \\
\hline Wheat & $\alpha$-gliadin family members & Indels & Decreased gluten & {$[35]$} \\
\hline Wheat & $\operatorname{Pin} B$ & $\begin{array}{l}\text { Gene insertion and } \\
\text { replacement }\end{array}$ & Genetic improvement & [109] \\
\hline Wheat & TaWaxy, TaMTL & $\begin{array}{l}\text { Gene insertion and } \\
\text { replacement }\end{array}$ & Induction of haploid plants & [110] \\
\hline Wheat & Ms45 & Base editing & Male-sterility & [53] \\
\hline
\end{tabular}

\subsubsection{Prospects in Plant Gene Editing}

CRISPR-Cas is a simple, precise, and user-friendly toolbox for plant gene editing. The tools can be explored in various ways in the future: (i) The genome structure and gene function can be elucidated in plants including visualizing gene loci in humans. (ii) In synthetic biology, CRISPR can be used for introducing desired foreign genes with sgRNA with specific strong promoters and transcriptional regulators in the plant for novel products and functions. In the C4 rice project [111], where changes in the photosynthetic apparatus failed to increase carbon fixation, CRISPR can be useful in editing the photosynthetic apparatus and in fixing the carbon efficiently [112]. (iii) Easy multiple gene-editing simultaneously at multiple loci in domesticated and non-domesticated plants is the need of the hour to provide global food security. Increasing the speed of domestication of crops can prevent loss of diversity in plants and can feed an increasing population such as in the case of domestication of wild tomato [113]. (iv) The specificity and efficiency of gene editing can be improved by homology-directed repair [114]. (v) Weeds and pests can be eliminated with the help of gene drives. (vi) Regulatory authorities and researcher's societies should work in coordination and should not allow random, illicit genome editing and gene drives until a strong controlled framework is available. The above all-important applications demonstrate the wide use of the CRISPR tool and all the improved edited plants produced are only the tip of the iceberg. Hence, genome editing by CRISPR-Cas9/Cas12a and plant breeding will help society overcome food scarcity for exponentially increasing populations [48]. Conclusively, CCS can tailor plants for survival in unfavorable conditions, can provide ample food for all, and can make the world a good place to live.

The CRISPR-Cas13a system is used to engineer resistance against plant RNA viruses. Multiple genes are targeted by this system using multiple guide RNAs and by expressing them under polymerase II, thus enhancing targeting efficiency. Due to high mismatch, high sensitivity of this system, differentiation, and proper intervention is possible between highly similar viral strains. This system can also detect a single copy of RNA with high specificity and sensitivity, a requirement for viral detection in the early detection of the virus [115]. Cas13a along with CRISPR-Cas9 was employed in targeting the RNA and DNA viruses directly in non-transgenic cucumber, providing plant dual immunity [68].

\subsection{In Therapeutics}

\subsubsection{For Treating Genetic Diseases}

The CRISPR-Cas system has been widely used in the correction of human genetic diseases including Duchenne muscular dystrophy (DMD) [116], $\alpha-1$ antitrypsin deficiency (AATD) [117], hemophilia [118], hematopoietic diseases [119], and hearing loss [120]. 
The genetic corrections are carried out by CRISPR-Cas9-based hematopoietic stem and progenitor cells (HSPCs) [121], recovering pathogenic mutation in induced pluripotent stem cells (iPSCs) in normal hemoglobin, etc. [122]. DMD is caused by a mutation of the dystrophin gene. In DMD patients, the exon 50 deletion coding rod domain of dystrophin places exon 51 and the preceding exons out of frame. In addition, the deletional mutation of exon 44 places the dystrophin genes out of frame. The in vivo delivery of Cas 9 and sgRNA was performed with adeno-associated virus serotype 9 (AAV9). Thus, the group using AAV9-mediated Cas9 and sgRNA skipped or restored the exon 50 deletions and prevented mutations of exon 44 using CRISPR-mediated skipping of the surrounding genes [116]. AATD is a hereditary liver disorder caused by a mutation in the gene encoding the serine protease inhibitor (SERPINA1). Severe patients homozygous for this deficiency have a lump of proteins in the liver and reduced circulation of $\alpha-1$ antitrypsin. In a mouse model of AATD, researchers destroyed the mutant version of the SERPINA1 and obtained dissolution of liver fibroids and mutant protein aggregation [117].

Blood disorders, such as $\beta$-thalassemia and sickle cell diseases (SCD), are caused by the structural or reduced production of $\beta$-chains, thus decreasing the oxygen-carrying capacities of hemoglobin. Bone marrow cells are harvested using CRISPR-Cas technology for the production of fetal hemoglobin to fight against the symptoms of such diseases. The 200 bp BCL11A erythroid enhancer including GATAA motif deletion leads to increased production of $\gamma$-hemoglobin expression in K562 cells [119]. Fetal hemoglobin with $\gamma$ chain is a natural form of the oxygen-carrying protein that binds oxygen better than adult hemoglobin. Hearing loss due to mutant Tmc1 was targeted by Staphylococcus aureus Cas9 in Beethoven mice and a DFNA36 human cell line. Tmc1 is a gene encoding a poreforming subunit of mechanosensory transduction channels in inner-ear hair cells. The AAV-mediated delivery of Cas9 prevented deafness in Beethoven mice up to one-year post injection [120].

\subsubsection{For Management of Infectious Diseases}

Viruses are known to cause latent infections, which include human immunodeficiency virus (HIV), herpes simplex virus (HSV), Epstein-Barr virus (EBV), human cytomegalovirus (HCMV), Kaposi's sarcoma-associated herpesvirus (KSHV), John Cunningham virus (JCV), etc. [123]. For many infectious viral diseases such as respiratory syncytial virus (RSV), influenza, and EBV, there are no effective vaccines that clear the viral genome completely from the host. The CRISPR-Cas system represents a promising tool to fight viral infections. It is also predicted that CRISPR can edit the human genome to prevent people from being infected.

\section{Control of Human Immunodeficiency Virus (HIV)}

Human immunodeficiency virus DNA is reversely transcribed and depends upon a host for its replication similar to that in any other RNA virus [124] and integrates into the genome acting as a latent reservoir, which creates a problem in its eradication [125]. Highly active antiretroviral therapy (HAART) is the current method used to stop replication but fails to fight the latent infection. Therefore, for fighting latent infections due to HIV, CRISPR-Cas technology has been widely prevalent in destroying HIV proviruses [125].

Targeting of the various viral gene can be summarized in few points: (i) In a study, long terminal repeat (LTR) regions on both ends of viral genes were targeted by CRISPR-Cas9 into HIV-1 LTR expression-dormant and inducible T cells. The results showed a significant loss of LTR expression due to cleavage and mutation of LTR target sites [126]. (ii) The glycoprotein CD4 on T cells and CC chemokine receptor type 5 (CCR5; formerly termed CKR5) or CXC chemokine receptor type 4 (CXCR4) facilitate HIV-1 entry into the host cell, and therefore, HIV-1-CCR5 interactions can check the entry of HIV and treatment of AIDS. Hence, in a study, the Cas9 was reprogrammed to destroy plasmid-encoded human CCR5 and obtained 33\% mutation at the CCR5 locus [127]. (iii) CXCR4 binds to the gp120 envelope protein and mediates viral infection in the $\mathrm{CD}^{+} \mathrm{T}$ cells. Therefore, a study found 
that targeting two sites in CXCR4 led to ablation of CXCR4, making the modified cells resistant to X4-type HIV-1 infection [128]. (iv) Simultaneous genome editing of CXCR4 and CCR5 by CRISPR-Cas9 in various $\mathrm{T}$ cell lines and primary CD4 ${ }^{+} \mathrm{T}$ cells showed no off-target effect and cytotoxic effects on cell viability $[129,130]$. Dash and coworkers targeted the HIV-1 subgenomic particles surrounding the LTR and gag gene and reported the removal of proviral DNA without any off-target effects [131]. A study by He Jiankui showed that deleting 32 amino acids coding CCR5 and known for providing resistance to HIV-1 infection does not protect from all strains of HIV [132]. Although, He reported in 2018 the birth of the first genetically edited babies Lulu and Nana, the sequencing of DNA from their placenta, umbilical cord, and cord blood to assess on- and off-target mutations showed off-targeted effects and mosaicism in both babies. Neither of them exhibited CCR5 32 variants protective against HIV. Cas12a completely inactivates HIV with sgRNA and stands as a promising tool for genome editing with high specificity and activity [133].

\section{Detection of Severe Acute Respiratory Syndrome Coronavirus 2 (SARS-CoV-2)}

Researchers are using different CRISPR-Cas technologies for the early, rapid, and efficient detection of viruses. In a recent study, sequence-specific recognition of HIV-1 was performed by CRISPR-Cas-assisted nanopores [134]. Similarly, the recent outbreak of a novel coronavirus SARS-CoV-2 responsible for the global COVID-19 pandemic is detected by all-in-one dual CRISPR-Cas12a (termed "AIOD-CRISPR") assay in which a pair of crRNAs was introduced to detect nucleic acids of SARS-CoV-2 (DNA and RNA) and HIV [135]. Currently, the novel coronavirus SARS-CoV-2 deadly outbreak has 2,642,826 confirmed deaths and 119,220,681 confirmed cases worldwide according to WHO data (5:13 pm CET, 14 March 2021) (https:/ / covid19. who.int/ (accessed on 14 March 2021)). The rapid detection of the novel pathogen has laid out technological challenges for the scientific field. Hou et al. were able to develop a highly sensitive CRISPR-based diagnostic tool for the detection of strains genetically such as SARS-CoV. Although research is in evaluation, it promises shorter run times and higher sensitivity detection than RT-PCR [136].

\section{Management of Other Infectious Diseases}

Viral diseases are difficult to treat due to the high mutation rate and high latency of infections. One such virus is herpes simplex virus type 1 (HSV-1), which can perform either lytic or latent infections [137]. The virus expresses latency-associated transcript (LAT) genes during latency and remains protected in the cytoplasm or nucleus without or with fewer symptoms in the host. However, reactivation of the viruses into lytic infection implicates disease and, in some cases, death. Rohem et al. designed a mixture of sgRNA that targets ICP0, ICP4, and ICP27 immediate proteins crucial for viral replication and that eliminates viral infections [137].

MicroRNAs (miRNAs) are noncoding, short RNAs found in Epstein-Barr virus (EBV) that regulate viral and host cell gene expression. The EBV-miRNAs are associated with several biological functions also in the development of cancer [138]. Further study revealed that sgRNA successfully targeted and downregulated EBV miRNAs such as miR-BART5, miR-BART6, and miR-BART16 in latency. For lytic infection, the authors designed sgRNA against the viral EBV nuclear antigen 1 (EBNA1) and several genes under the EBV origin of replication (OriP). A similar approach was tested for HSV-1 and human cytomegalovirus (HCMV) [139]. A decrease in viral replication and abrogation of replication upon reactivation from latency in HSV-1 were observed. The adenoviral-mediated specific Cas 9 targeting of gene encoding latency-associated nuclear antigen (LANA) decreased episomal load, which is necessary for the maintenance of Kaposi's sarcoma-associated herpesvirus (KSHV) in the host [140], and similarly targeted genes responsible for the production and the fitness of HSV-1 and HCMV abrogate viral replication [139].

In a study for HCMV, singleplex (1 cgRNA) and multiplex (3 cgRNA's) lentivirusmediated targeting of the start codon and UL122/123 gene were performed, respectively. The UL122/123 gene encodes for early proteins responsible for viral replication. In single- 
plex, site-specific cleavage was induced in the UL122/123 gene by one cgRNA, whereas in multiplex, $3300 \mathrm{bp}$ were deleted in the UL122/123 gene using three cgRNAs. This led to a prominent reduction in immediate-early (IE) protein expression. The new virion production was reduced by CRISPR-Cas9 technology up to 98\% [141]. CRISPR-Cas9 has been used to replace protective vaccines with endogenously produced antibodies in primary human B cells, resulting in potency and protection against influenza, EBV, and respiratory syncytial virus (RSV) infections [142].

Wollebo and coworkers targeted human polyomavirus (JCV) genes encoding viral early proteins and $\mathrm{T}$ antigens. The proteins were responsible for viral reactivations and lytic infections. The analysis revealed that targeting of $\mathrm{N}$-terminal of $\mathrm{T}$ antigens and mutations in viral proteins perturbed the replication and function of viral proteins, preventing viral replication in the cells [143]. Conclusively, the specificity and precision of CRISPR-Cas technology and development in the delivery agent of the CRISPR-Cas system in an animal model can cure the herpesvirus infection.

\subsubsection{For Management of Cancers}

Cancer is a disease characterized by multiple oncogene and epigenetic mutations. CRISPR-Cas technology, a versatile technology for gene editing can be easily transferred to the cells and has extensive application in cancer biology and oncology [144]. The CRISPR-Cas system represents a suitable tool for the exploration of different oncological mechanisms including tumor occurrence, development, and treatment by repairing mutations and knockout genes. The detection of cancer can be conducted by Cas13a using specific high-sensitivity enzymatic reporter unlocking (SHERLOCK). The SHERLOCK platform is a rapid and high-sensitive method to detect nucleic acids. In this, recombinase polymerase amplification of DNA or RT-RNA is performed, followed by T7 RNA polymerase transcription. The method detected these transcribed nucleic acids using Cas13a reporter probes, and fluorescence was measured [145]. The different strategies followed to edit the genome caused mutations that facilitated proto-oncogene inhibition and tumor suppressor gene activation [146,147].

(i) Inhibition of Gain in function mutation (GiF) of proto-oncogenes: CRISPR-Casmediated gene knockout of CD38 in human lung adenocarcinoma A549 cells inhibited anchorage-independent cell growth and development, cell invasion, and xenograft growth in nude mice [148]. One example of GiF is inhibition of the PIK3C3 and FGFR pathways by a first-class compound MPT0L145 that exhibited significant anti-bladder cancer activity via autophagy-dependent cell death. MPT0L145 further exhibited stronger cytotoxicity compared to other PIK3C3 inhibitors. However, CRISPR-Cas9-mediated knockout of the ATG5 gene reversed MPT0L145-induced cell death by autophagy introduction [149].

(ii) Inhibition of Loss in function mutation (LiF) of tumor suppressor genes: the LiFs of Acvr1b, Acvr2a, and Arid 2 behaved as a tumor suppressor in colorectal cancer. It was also observed that mutations in the receptors of activin and transforming growth factor- $\beta$ (TGF- $\beta$ ) promoted the formation of tumors synergistically [150]. BAP1 is a tumor suppressor and regulates chromatin accessibility. The LiF of BAP1 by CRISPR-Cas9 in human cholangiocyte organoids resulted in the acquisition of malignant features upon xenotransplantation. The result demonstrated a key aspect of BAP1's tumor suppressor function [151]. LiF or GiF CRISPR-Cas9 gene knockout aides in cervical cancer detection, prevention of HPV infection, reduction in occurrence and death due to ovarian cancer, and deeper understanding of endometrial cancer [28].

(iii) Immunotherapy is a biological therapy that strengthens our flawed immune cells to fight cancer. Immune cells, such as T cells, are genetically modified using viral or nonviral vectors to form chimeric antigen receptors (CARs) on the cell surface. The engineered $\mathrm{T}$ cell CARs recognize and kill the targeted tumor cells [152]. The CRISPR-Cas targeted gene delivery in the alpha locus of T cell CAR specific for CD19 led to stable CAR expression and increased T cell potency compared to conventional CAR T cells in a mouse model of acute lymphoblastic leukemia [153]. Multiplex targeting of the endogenous T 
cell receptor, $\beta_{2}$ microglobulin (B2M), and programmed cell death protein 1 (PD-1) by CRISPR-Cas simultaneously resulted in gene-edited CAR T cells and potential antitumor activities $[153,154]$.

(iv) Inhibition of checkpoint molecules: CRISPR-Cas inhibition of checkpoint molecules such PD-1 [154], lymphocyte activation gene 3 (LAG3) [155,156], and cytotoxic T-lymphocyte protein (CTLA4) [156] also demonstrated antitumor activities.

\subsubsection{Prospects in Therapeutics and Management of Infectious Diseases}

The research data discussed above and the many more generated elsewhere provide greater insight into exploring new human diseases. CRISPR-edited constructs for the treatment of various genetic diseases such as sickle cell anemia, eye diseases, and cancer have shown promising effects in animal models. Although tissue-specific delivery of genome editors remains a key challenge in clinical applications of CRISPR, in vivo delivery tools are needed for cardiomyocyte, neurocytes, and immune cells for precise genome editing of genetic diseases and for analyzing genome-edited data. Human lung diseases, viz., cystic fibrosis causing a mutation in the cystic fibrosis transmembrane regulator (CFTR), was modified precisely by CRISPR-edited corrective CFTR sequences [157]. The use of CRISPRCas gene-targeted editing successfully removed Duchenne muscular dystrophy causing mutations in dystrophin proteins $[158,159]$. Patients with sickle cell disease and transfusiondependent $\beta$-thalassemia were recently administered with BCL11A transcription factor targeting CRISPR-Cas9-edited CD34+ cell-enriched CTX001 and showed reactivation and a significant increase in fetal hemoglobin production [160]. Similar potential therapeutic strategies utilizing precise CRISPR-edited gene constructs are expected to be developed in the near future to correct the gene mutations of patients suffering from other human genetic disorders.

Several animal models such as chicken, cow, goats, and pigs are constructed by CRISPR to form bio-models to study humans and animal livestock. The ever-increasing demands of organs will be also reduced by these bio-models [161]. Specific human organs can be generated from animal blastocysts by disabling organ development in the host utilizing CRISPR [162]. In addition, longtime graft rejections will be improved by CRISPR. The applications of CRISPR-Cas9 in diverse fields such as transplantation can be performed using the manipulation of T cells and hematopoietic stem cells (HSCs) performed to cure blood cell-related diseases [163]. Transgenic pigs can be created with the removal of complications associated with porcine xenotransplantation [164]. Moreover, the CRISPRCas System is a potential tool in antiaging studies [165]. CRISPR-Cas system application for therapy is summarized in Table 6 .

Table 6. The application of CRISPR-Cas in therapeutics. Abbreviations: HBV, hepatitis B virus; IE protein, immediate early protein; RBC, red blood cells; ROS, reactive oxygen species.

\begin{tabular}{|c|c|c|c|c|}
\hline Disease & Target Genes & Editing Process & Results & Reference \\
\hline Cataracts & EGFP, Crygc & Indels & Gene correction of Crygc gene & [166] \\
\hline $\begin{array}{l}\text { Chronic granulomatous } \\
\text { disease (CGD) }\end{array}$ & CYBB & $\begin{array}{l}\text { Single point } \\
\text { mutation }\end{array}$ & $\begin{array}{c}\text { Restoration of ROS activity on } \\
\text { phagocytic cells }\end{array}$ & {$[167]$} \\
\hline Coronary heart disease & PCSK9 & Insertion/deletion & Prevent coronary heart disease & [168] \\
\hline Cystic fibrosis $(\mathrm{CF})$ & CFTR & Base editing & $\begin{array}{c}\text { Normal recovery of CFTR } \\
\text { expression }\end{array}$ & [157] \\
\hline $\begin{array}{l}\text { Diabetes mellitus type } 1 \\
\text { (DM1) }\end{array}$ & $D M P K$ & Gene editing & $\begin{array}{c}\text { Play important role in disease } \\
\text { etiology }\end{array}$ & [169] \\
\hline $\begin{array}{l}\text { Duchenne muscular } \\
\text { dystrophy (DMD) }\end{array}$ & exon 44 & Gene deletion & Restoration of dystrophin protein & [116] \\
\hline $\begin{array}{l}\text { Duchenne muscular } \\
\text { dystrophy (DMD) }\end{array}$ & Dmd & Gene deletion & Restoration of dystrophin protein & [170] \\
\hline Hemophilia B andA & $F 9$ and $F 8$ & $\begin{array}{l}\text { Gene knock-in and } \\
\text { alteration }\end{array}$ & Control bleeding process & [118] \\
\hline Hearing loss & Tmc1 & Gene disruption & Prevention of deafness & [120] \\
\hline
\end{tabular}


Table 6. Cont

\begin{tabular}{|c|c|c|c|c|}
\hline Disease & Target Genes & Editing Process & Results & Reference \\
\hline Hematopoietic diseases & BCL11A & Gene deletion & $\begin{array}{c}\text { Increased production of } \\
\gamma \text {-hemoglobin }\end{array}$ & [119] \\
\hline Huntington disease (HD) & HTT & $\begin{array}{l}\text { Small targeted } \\
\text { deletions }\end{array}$ & Terminating HTT expression & [171] \\
\hline $\begin{array}{l}\text { Sickle cell disease (SCD) } \\
\text { Sickle cell disease (SCD) }\end{array}$ & $\begin{array}{c}H B B \\
B C L 11 A\end{array}$ & $\begin{array}{l}\text { Indels } \\
\text { Gene interference }\end{array}$ & $\begin{array}{l}\text { RBC formation } \\
\text { RBC formation }\end{array}$ & $\begin{array}{l}{[121]} \\
{[172]}\end{array}$ \\
\hline WPW syndrome & PRKAG2 & Insertion/deletion & $\begin{array}{c}\text { Correction of PRKAG2 cardiac } \\
\text { syndrome }\end{array}$ & {$[173]$} \\
\hline$\alpha 1$-antitrypsin & hSERPINA1 & Gene disruption & $\begin{array}{l}\text { Reduced expression of liver } \\
\text { fibrosis markers }\end{array}$ & [117] \\
\hline$\beta$-thalassemia & $H B B$ & Mutation deletion & RBC formation & [174] \\
\hline \multicolumn{5}{|c|}{ Cancer Tissue Therapy } \\
\hline Ataxia-telangiectasia & ATM & Gene knockout & $\begin{array}{l}\text { Increased ATM-independent } \\
\text { repair mechanism }\end{array}$ & {$[175]$} \\
\hline Bladder cancer & ATG5 & Gene knockout & Cytotoxicity suppression & [149] \\
\hline $\begin{array}{l}\text { Cervical cancer } \\
\text { Cholangiocarcinoma }\end{array}$ & $\begin{array}{c}E 6 \text { and } E 7 \\
B A P 1\end{array}$ & Gene knockout & $\begin{array}{l}\text { Anti-tumor activities } \\
\text { Loss of malignancy }\end{array}$ & $\begin{array}{l}{[176]} \\
{[151]}\end{array}$ \\
\hline Colorectal cancer & $\begin{array}{l}\text { Acvr1b, Acvr } 2 a, \\
\text { and Arid2 }\end{array}$ & Gene knockout & Suppression of cancer & [150] \\
\hline $\begin{array}{l}\text { Human lung } \\
\text { adenocarcinoma A549 cells }\end{array}$ & CD38 & Gene knockout & $\begin{array}{l}\text { Inhibited anchorage-independent } \\
\text { cell growth }\end{array}$ & [148] \\
\hline $\begin{array}{c}\text { Hypertrophic } \\
\text { cardiomyopathy (HCM) }\end{array}$ & MYBPC3 & Mutation correction & $\begin{array}{l}\text { Maintain sarcomere structure and } \\
\text { regulate relaxation/contraction }\end{array}$ & {$[177]$} \\
\hline Leukemia and lymphoma & TRAC locus & Knock-in & Enhanced anti-tumor capability & [152] \\
\hline Melanoma & $\begin{array}{c}P D-1, L A G 3 \text {, and } \\
\text { CTLA4 }\end{array}$ & & Anti-tumor activities & [155] \\
\hline $\begin{array}{l}\text { Nijmegen breakage } \\
\text { syndrome }\end{array}$ & NBS1 & Mutation correction & Decreased susceptibility of cancer & [178] \\
\hline Non-small cell lung cancer & NPM1 & Gene knockout & Anti-tumor activities & [179] \\
\hline Tumor & $B 2 M$ & Gene disruption & Anti-tumor activities & [153] \\
\hline Tumor & $P D-1$ & Gene disruption & Anti-tumor activities & [154] \\
\hline \multicolumn{5}{|c|}{ Cell Therapies } \\
\hline $\begin{array}{l}\text { Lung and esophageal } \\
\text { cancer }\end{array}$ & $P D-1$ of T cells & Gene knockout & Clinical trials & [180] \\
\hline \multicolumn{5}{|c|}{ Viral Infection } \\
\hline Chimeric hepatitis B & Repeat regions & Gene inactivation & Eradication of HBV infection & [181] \\
\hline HIV & LTR U3 region & Gene knockout & Loss of LTR expression & [126] \\
\hline HIV & CCR5 on T cells & Gene knockout & Reduced entry of virus & [127] \\
\hline HIV & CXCR4 & Gene knockout & Resistant to X4 HIV virus & [128] \\
\hline HIV & CXCR4 and CCR5 & Gene knockout & Cytotoxicity of cells & {$[129,130]$} \\
\hline HIV & $\begin{array}{l}\text { Subgenomic } \\
\text { particles }\end{array}$ & Gene knockout & Removal of proviral DNA & {$[131]$} \\
\hline HSV-1 & ICP0, ICP4, ICP27 & & Abrogation of viral infection & [137] \\
\hline Human cytomegalovirus & UL122/123 & & $\begin{array}{l}\text { Decreased IE protein expression, } \\
\text { reduced production of new virions }\end{array}$ & {$[141]$} \\
\hline $\begin{array}{c}\text { Human polyomavirus } \\
\text { (JCV) } \\
\text { Kaposi's }\end{array}$ & $\begin{array}{l}\text { N-terminal of } \\
\text { T-antigens }\end{array}$ & & Suppressed viral replication & [143] \\
\hline $\begin{array}{c}\text { sarcoma-associated } \\
\text { herpesvirus }\end{array}$ & LANA & & Decreased episomal load & [140] \\
\hline \multicolumn{5}{|c|}{ Bacterial Infection } \\
\hline $\begin{array}{l}\text { Burkitt lymphoma } \\
\text { Hodgkin's disease }\end{array}$ & BART5, BART6 & Gene deletion & Suppressing the viral replication & [139] \\
\hline Escherichia coli & $\begin{array}{c}f t s A, a s d, m s b A, \\
n u s B\end{array}$ & Gene knockout & Antibiotic resistance & {$[182]$} \\
\hline Escherichia coli & NDM-1, CTX-M-15 & Gene truncation & Carbapenem resistance & [183] \\
\hline Escherichia coli & blaTEM, blaSHV & Gene truncation & $\begin{array}{l}\text { Re-sensitization to } \beta \text {-lactam } \\
\text { resistance }\end{array}$ & {$[184]$} \\
\hline Staphylococcus aureus & aph-3, mесA & Gene deletion & $\begin{array}{c}\text { Confer resistance against } \\
\text { kanamycin }\end{array}$ & [185] \\
\hline
\end{tabular}


Brian Madeux, an American man with Hunter's syndrome, received AAV-facilitated ZFN treatment in 2017. This highlighted the potential of gene editing for the first time in the treatment of genetic diseases. In cancer, CAR T cell therapy has been recognized as a "breakthrough therapy" and was approved in 2017 by the US Food and Drug Administration (FDA) for the treatment of leukemia and lymphoma [186], and soon, human trials of CRISPR will start. CRISPR technology not only helps in treatment but also in diagnosing diseases and reducing stress. CRISPR diagnostic kits and chips, which will be available to detect major diseases in no time, are upcoming [136]. Gene editing technologies facilitate the eradication of human diseases, for example, gene drive transfers and stabilizing altered genes in a wild population by a hundred percent. Similar to a study conducted in 2018, CRISPR crashed an entire population of mosquitoes by passing on infertility for a dozen generations using gene drive [187]. However, we cannot overlook the deleterious effects of gene drives on the human population from ethical perspectives.

\subsection{In the Food Industry}

Genome engineering of microorganism (bacteria and fungi) using CRISPR-Cas technology has been conducted in various research for improving cellular metabolism and production of valuable cellular metabolites [188]. Metabolic pathway such as the mevalonate pathway leading to the production of cholesterol and monoterpenes, which are commercially important in different traditional and modern pharmaceutical and cosmetic industries. Genome editing in yeast increases the mevalonate by more than 41 -fold in comparison to non-edited strains [189]. The CRISPR-Cas system was also used to integrate the $\beta$-carotene synthetic pathway into the genome of Escherichia coli and for the modification of central metabolic and methylerythritol-phosphate (MEP) pathways for $\beta$-carotene overproduction [190]. The knockout of genes in Corynebacterium and the integration of synthetic single-stranded oligo-deoxyribonucleotides with the help of recombinase RecT produced high titers of $\gamma$-aminobutyric acid within a few weeks [191]. The production of succinate [192], galactaric acid [193], citric acid [194], and fatty acids have been enhanced by knocking out several genes and by optimizing the metabolic pathways [195]. Additionally, folic acid, biolipids, and nucleosides production from filamentous fungus Ashbya gossypii are enhanced by CRISPR-Cas9 markers with fewer nucleotide deletions and insertions [196].

\section{Prospects in the Food Industry}

CRISPR-Cas genome editing to increase the production of metabolites not only meets the increasing demand of society but also reduces pressure on the production sector and natural resources. CRISPR not only edits new organisms for metabolite production but also removes harmful contaminants formed during the process of formation. Mycotoxin contamination removal during the production of Monascus red, a food colorant, is one recent example [197]. CRISPR technology has shown high responses in crop improvement but has yet is to be explored in the field of plant synthetic biology and crop domestication.

Plant synthetic biology involves engineering traditional crops to design and produce novel bioproducts. CRISPR with its extraordinary feature of editing several genes together, i.e., multiplexing and integrating two or more genes at the predetermined location, i.e., gene stacking, is perfect for this. For example, to increase photosynthesis in C4 plants, the catalyzing properties of ribulose-1,5-bisphosphate carboxylase/oxygenase (Rubisco), an enzyme that catalyzes a rate-limiting step of photosynthesis, is increased by enhancing Rubisco production in plants. Therefore, three genes encoding Rubisco-larger subunit (LS), smaller subunit (SS) and Rubisco assembly factor 1 (RAF1) - were CRISPR-edited and overexpressed [112]. Several metabolic enzymes involved in crop yield, quality, and resistance if mutated in a frame by saturation mutagenesis would improve crops faster and better [198]. The application of the CRISPR-Cas system in the food industry is summarized in Table 8. 
Table 7. The application of CRISPR-Cas in the food industry. Abbreviations: CRISPRi, CRISPR interference; GFP, green fluorescent protein; MUCICAT, multicopy chromosomal integration using CRISPR-associated transposases.

\begin{tabular}{|c|c|c|c|c|}
\hline Target Species & Target Gene(s) & Editing Process & Results & References \\
\hline \multicolumn{5}{|c|}{ Bacteria } \\
\hline Ashbya gossypii & $A D E 2$ & Nucleotide deletions & $\begin{array}{l}\text { Production of folic acid, biolipids, } \\
\text { and nucleoside }\end{array}$ & [196] \\
\hline Bacillus smithii & $p y r F, a m y E, \operatorname{trp} C 2$ & $\begin{array}{c}\text { Gene deletion and } \\
\text { insertion/recombination }\end{array}$ & $\begin{array}{l}\text { Capable of using five and six } \\
\text { carbon containing sugars }\end{array}$ & {$[199,200]$} \\
\hline Bacillus subtilis & cypX, yvmA & Gene deletion and insertion & $\begin{array}{l}\text { Production of several enzymes } \\
\text { and low molecular weight } \\
\text { substances }\end{array}$ & [201] \\
\hline $\begin{array}{l}\text { Clostridium } \\
\text { autoethanogenum }\end{array}$ & $a d h, 2,3-b d h$ & Gene deletion and insertion & $\begin{array}{l}\text { Production biofuels and } \\
\text { 2,3-butanediol utilizing } \\
\mathrm{CO}, \mathrm{CO}_{2} \text {, and } \mathrm{H}_{2}\end{array}$ & [202] \\
\hline Clostridium beijerinckii & Ack, adhE & Gene deletion and insertion & $\begin{array}{l}\text { Biofuels and biochemicals } \\
\text { production }\end{array}$ & [203] \\
\hline $\begin{array}{l}\text { Clostridium } \\
\text { cellulolyticum }\end{array}$ & pyrF, MspI & Gene deletion and insertion & $\begin{array}{l}\text { Model for production of } \\
\text { renewable biochemicals }\end{array}$ & [204] \\
\hline Clostridium ljungdahlii & $\begin{array}{l}\text { pta, adhE1, ctf } \\
\text { and pyrE }\end{array}$ & Gene deletion & $\begin{array}{c}\text { Production of ethanol from } \\
\text { synthesis gas }\end{array}$ & [205] \\
\hline $\begin{array}{l}\text { Clostridium } \\
\text { pasteurianum }\end{array}$ & cpaAIR & Gene deletion & $\begin{array}{l}\text { Potential biofuel from conversion } \\
\text { of waste glycerol into ethanol }\end{array}$ & [206] \\
\hline $\begin{array}{l}\text { Corynebacterium } \\
\text { glutamicum }\end{array}$ & Pgi,pck & CRISPRi & $\begin{array}{c}\text { Increased production of } \\
\gamma \text {-aminobutyric acid }\end{array}$ & [207] \\
\hline Cyanobacteria & $g \lg C, g l t A, p p c$ & Gene deletion and insertion & Increased production of succinate & [208] \\
\hline Escherichia coli & Growth-related genes & $\begin{array}{l}\text { CRISPRi, multiplexed } \\
\text { CRISPRi, multiplexed RNA, } \\
\text { RNA targeting, MUCICAT }\end{array}$ & $\begin{array}{l}\text { Enhanced model for production of } \\
\text { bioproducts and enzymes }\end{array}$ & {$[209,210]$} \\
\hline Lactobacillus reuteri & lacL & Gene deletion and insertion & $\begin{array}{l}\text { Model for new single stranded } \\
\text { DNA editing }\end{array}$ & [211] \\
\hline $\begin{array}{l}\text { Streptococcus } \\
\text { thermophiles }\end{array}$ & Growth-related genes & Genome editing & $\begin{array}{l}\text { Pro-biotic activity and } \\
\text { fermentation }\end{array}$ & [212] \\
\hline Streptomyces albus & $\operatorname{redF}$ & Gene deletion & Bioactive products & [213] \\
\hline Streptomyces coelicolor & actII-orf4, glnR, redF & $\begin{array}{l}\text { Gene deletion and insertion, } \\
\text { CRISPRi }\end{array}$ & $\begin{array}{l}\text { Improvement in genome editing } \\
\text { efficiency as a model }\end{array}$ & [214] \\
\hline Streptomyces rimosus & $z w f 2, \operatorname{dev} B$ & $\begin{array}{l}\text { Gene mutation and } \\
\text { disruption }\end{array}$ & Increased yield of oxytetracycline & [215] \\
\hline $\begin{array}{l}\text { Streptomyces } \\
\text { roseosporus }\end{array}$ & PKS gene cluster & Gene cluster activation & $\begin{array}{c}\text { Production of auroramycin and its } \\
\text { aglycon }\end{array}$ & [216] \\
\hline $\begin{array}{l}\text { Streptomyces } \\
\text { viridochromogenes }\end{array}$ & $\begin{array}{l}\text { Biosynthetic gene } \\
\text { cluster }\end{array}$ & Gene knock-in & $\begin{array}{c}\text { Production of pentangular type II } \\
\text { polyketide }\end{array}$ & [213] \\
\hline Tatumella citrea & $t k r A, g l k$ & MUCICAT, allelic exchange & $\begin{array}{l}\text { Successful application of the } \\
\text { method, multiplex genome editing } \\
\text { system }\end{array}$ & {$[217,218]$} \\
\hline \multicolumn{5}{|c|}{ Yeast } \\
\hline Agaricus bisporus & PPO & Gene disruption & Non-transgenic variety & [88] \\
\hline Alternaria alternata & $p k s A, b r m 2$ & Gene deletion/insertion & $\begin{array}{l}\text { Established pyr4 as selection } \\
\text { marker and GFP for protein } \\
\text { tagging }\end{array}$ & [219] \\
\hline Aspergillus aculeatus & alba & Gene mutation & $\begin{array}{l}\text { Potential genome editor in } \\
\text { filamentous fungi }\end{array}$ & [220] \\
\hline Aspergillus brasiliensis & pyrG & Gene mutation & $\begin{array}{l}\text { Potential genome editor in } \\
\text { filamentous fungi }\end{array}$ & [221] \\
\hline Aspergillus carbonarius & ayg1 & Gene mutation & $\begin{array}{l}\text { Potential genome editor in } \\
\text { filamentous fungi }\end{array}$ & {$[220,222]$} \\
\hline Aspergillus fumigatus & $p k s P$ & Gene cleavage & $\begin{array}{l}\text { Potential toolbox for decreasing } \\
\text { pathogenicity }\end{array}$ & [223] \\
\hline
\end{tabular}


Table 8. The application of CRISPR-Cas in the food industry. Abbreviations: CRISPRi, CRISPR interference; GFP, green fluorescent protein; MUCICAT, multicopy chromosomal integration using CRISPR-associated transposases.

\begin{tabular}{|c|c|c|c|c|}
\hline Target Species & Target Gene(s) & Editing Process & Results & References \\
\hline Aspergillus luchuensis & brlA, niaD, amyA & Gene mutation & $\begin{array}{l}\text { Potential genome editor in } \\
\text { filamentous fungi }\end{array}$ & {$[220,224]$} \\
\hline Aspergillus nidulans & $y A$ & Gene mutation & $\begin{array}{l}\text { Potential genome editor in } \\
\text { filamentous fungi }\end{array}$ & [220] \\
\hline Aspergillus niger & $u d h$ & Gene deletion/insertion & $\begin{array}{l}\text { Increased production of galactaric } \\
\text { acid }\end{array}$ & [193] \\
\hline Aspergillus oryzae & $K u-70, \operatorname{lig} D$ & Gene deletion/insertion & $\begin{array}{l}\text { Construct plasmid for targeted } \\
\text { mutagenesis }\end{array}$ & [225] \\
\hline Candida albicans & $A D E 2$ & $\begin{array}{l}\text { Recombination and } \\
\text { multiplexed recombination }\end{array}$ & $\begin{array}{l}\text { Genetic manipulation for } \\
\text { increased biproducts }\end{array}$ & [226] \\
\hline Candida glabrata & $\begin{array}{l}\text { a GPI-anchored } \\
\text { aspartyl protease, } \\
\text { a putative } \\
\text { serine/threonine } \\
\text { kinase }\end{array}$ & Gene cleavage & $\begin{array}{l}\text { Understanding C. glabrata } \\
\text { virulence in vivo }\end{array}$ & [227] \\
\hline $\begin{array}{l}\text { Cryptococcus } \\
\text { Neoformans }\end{array}$ & $A D E 2, L 41, T s p 2$ & Gene cleavage & $\begin{array}{c}\text { Genome engineering in higher } \\
\text { fungi }\end{array}$ & [228] \\
\hline Fusarium fujikuroi & tHMGR, Cps/Ks & Gene knockout & $\begin{array}{l}\text { Improved gibberellic acid } \\
\text { production }\end{array}$ & [229] \\
\hline Ganoderma species & ura3 & Gene cleavage & Codon optimization & [230] \\
\hline Huntiella omanensis & MAT1-2-7 gene & Gene inactivation & Role in sexual reproduction & [231] \\
\hline Kluyveromyces lactis & GAL80, YKU & Gene deletion and insertion & Enhanced production strain & [232] \\
\hline $\begin{array}{l}\text { Myceliophthora } \\
\text { thermophila }\end{array}$ & $\begin{array}{l}\text { cre-1, res- } 1, \text { ght }-1, \\
\text { and alp-1 }\end{array}$ & Multigene disruption & $\begin{array}{l}\text { Enhanced hypercellulase } \\
\text { production }\end{array}$ & [233] \\
\hline Neurospora crassa & CLR-2, GSY-1 & Gene replacement & $\begin{array}{l}\text { Increased expression of cellulase } \\
\text { and luciferase }\end{array}$ & [234] \\
\hline $\begin{array}{l}\text { Penicillium } \\
\text { chrysogenum }\end{array}$ & pks17, amdS & Gene cleavage & $\begin{array}{l}\text { Potential genome editor in } \\
\text { filamentous fungi }\end{array}$ & [235] \\
\hline Phytophthora sojae & RXLR, Avr $4 / 6$ & Gene replacement & Control pathogenicity & [236] \\
\hline Pichia pastoris & AOX1, MPPI & Gene deletion & Production of iso-pentanol & [194] \\
\hline $\begin{array}{l}\text { Saccharomyces } \\
\text { cerevisiae }\end{array}$ & Growth-related genes & $\begin{array}{l}\text { CRISPRa, CRISPRi, } \\
\text { Multiplex metabolic } \\
\text { engineering }\end{array}$ & Increased bioproducts & {$[189,232]$} \\
\hline $\begin{array}{c}\text { Schizosaccharomyces } \\
\text { pombe }\end{array}$ & $r r k 1$ & Gene cleavage & CRISPR toolbox in S. pombe & [237] \\
\hline Talaromyces atroroseus & $P K S$ & Gene cleavage & $\begin{array}{c}\text { Production of } \\
\text { polyketide-nonribosomal peptide }\end{array}$ & [238] \\
\hline $\begin{array}{l}\text { Trichoderma reesei } \\
\text { Ustilago maydis }\end{array}$ & $\begin{array}{c}\text { ura5 } \\
b E 1, b W 2\end{array}$ & $\begin{array}{l}\text { Homologous recombination } \\
\text { Gene disruption }\end{array}$ & $\begin{array}{l}\text { Tool for genome engineering } \\
\text { Increased DNA repair system }\end{array}$ & $\begin{array}{l}{[239]} \\
{[240]}\end{array}$ \\
\hline Yarrowia lipolytica & $\begin{array}{l}\text { PEX10, KU70, } \\
\text { and MFE1 }\end{array}$ & Gene disruption & $\begin{array}{c}\text { Increased synthesis and storage } \\
\text { of lipids }\end{array}$ & {$[241]$} \\
\hline
\end{tabular}

The domestication of nutritionally rich but wild crops such as sweet potato, banana, cassava, and quinoa has the potential to fight nutritional insecurity and food scarcity $[60,61,72]$. CRISPR technology is precise, cheap, and effective for inserting the desired gene for longer shelf-life and removal of unwanted genes from these crops. In CRISPR-edited crops, the CRISPR-Cas gene-editing tool possesses unique advantages over older endonucleases in genome editing tools. Before CRISPR, molecular scissors such as Zinc finger nucleases (ZFN), transcription activator-like effector nucleases (TALENs), and meganucleases $(\mathrm{MN})$ were widely preferred for gene editing in crop plants. With the discovery of ZFN in 1986 [242] and of TALEN in 2011 [243], first-generation gene-editing tools and genome manipulations took heights. However, with the discovery of the prokaryotic adaptive immune system, there was the advent of a second-generation editing tool that was easy to construct [244], robust [245,246], feasible [247], and target-specific and was the most powerful technique for genome editing in plants [38]. According to the U.S. Department of 
Agriculture (USDA), CRISPR-edited foods are not the same as genetic modified organisms (GMOs) [88]. Therefore, such foods will be immune to regulations for GMOs.

Global growing population and climate change will play a crucial role in the future of agriculture. The predicted human population in 2050 will reach 9.6 billion. This will result in a $60 \%$ higher demand for staple crops. In association with limited cropland areas and unpredictable weather conditions, food scarcity could become one of the biggest global issues in the future [248]. Genome editing appears to be a suitable technology to overcome this threat. The application of genome-edited crops in agriculture grew worldwide over the past decades (Figure 7). In 2018, genome-edited crops were planted on $12 \%$ of the world cropland area. Despite limited data about the global application of specific genome editing techniques in agriculture, high-effective systems are preferred. Site-specific nucleases such as TALENs and CRISPR-Cas systems have revolutionized biological research and have become widespread genome editing tool in crop plants [249]. For a better understanding of the CRISPR significance, several journal publications for each genome editing technique reported on PubMed is shown in Figure 7. The interest of the scientific community in novel techniques reflects their popularity and possibility for future applications. As seen in Figure 7, the popularity of ZFN slightly increased after 2005 and that in TALENs, in contrast, increased rapidly after the year 2010. However, CRISPR's popularity is unambiguously higher in comparison to other genome editing techniques. Moreover, a slight decreasing number of publications related to ZFNs and TALENs in recent years is probably caused by CRISPR's significance. Therefore, we expect further expansion of the CRISPR-Cas system application in the field of genome engineering. 
APPLICATION OF GENOME-EDITED CROPS IN THE WORLD

$\square$ Cropland area planted with genome-edited crops $\square$ Cropland area planted with conventional crops
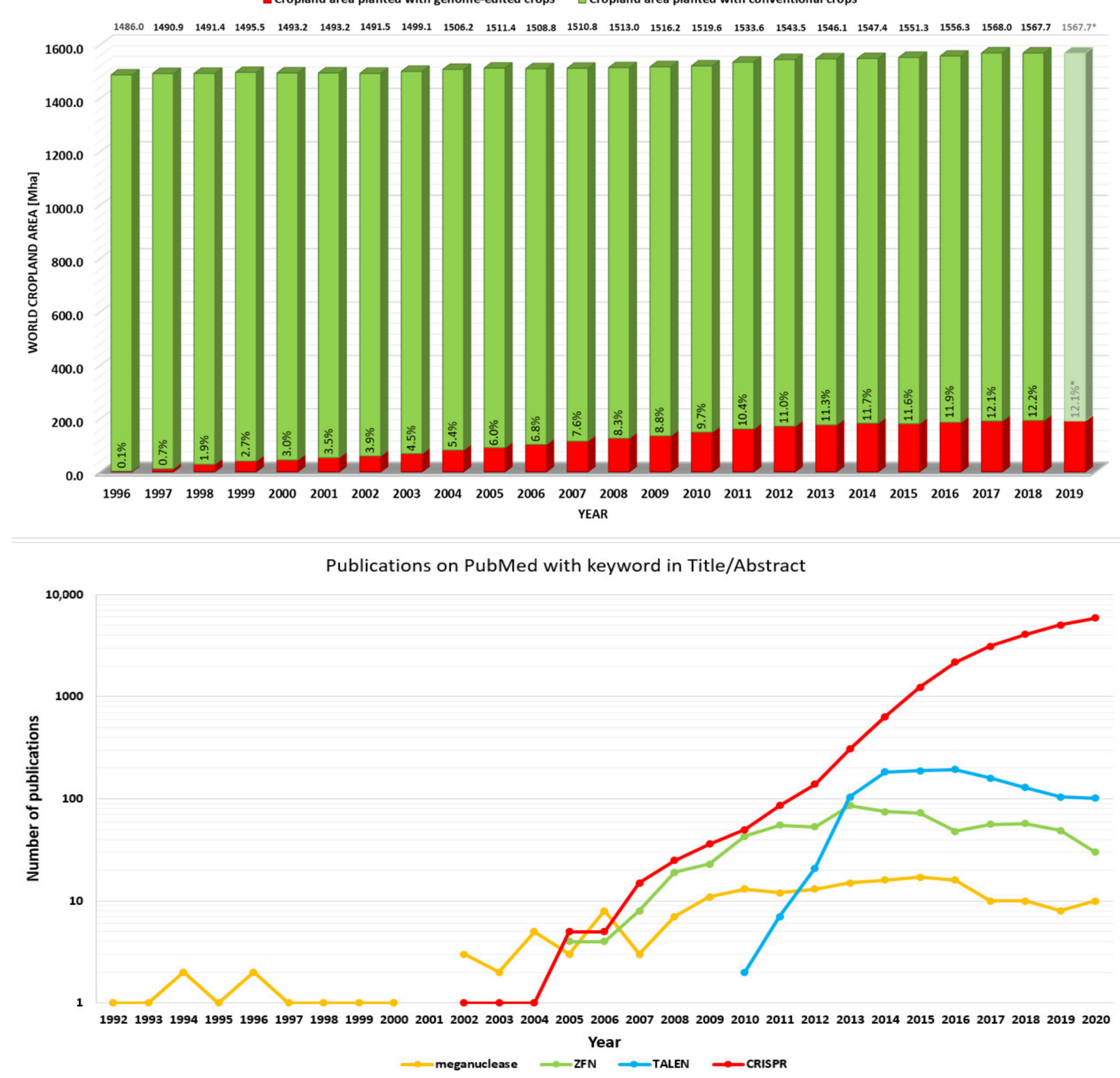

Figure 7. Top: Diagram represents the ratio of world cropland area planted with genome-edited crops (red column) and conventional crops (green column) since 1996. The numbers above the green columns represent a total world cropland area (sum of red and green column) in million hectares (Mha) in the corresponding year. The numbers above the red columns represent the percentage of world cropland area planted with genome-edited crops in the corresponding year. Due to absence of data for 2019 (total world cropland area), numeral values (colored gray and marked with an asterisk) are calculated according to the data of the total world cropland area in 2018. Bottom: Number of publications on PubMed with the keywords in their title/abstract. The following keywords were used: "meganuclease", "ZFN", "TALEN", and "CRISPR" [250-252].

\section{CRISPR-Cas9: Ifs and Buts}

A major limitation is the production of off-target effects in host cells, especially in mice embryos and adult human cells. The basic reason behind the off-target effects is the nonrecognition of target sequences by the 18-20 long nucleotide protospacer sequence in 
the sgRNA [253]. The sgRNA along with Cas9, despite widely used in genome editing, are limited by off-target effects and chromosomal translocation due to off-target cleavage. Choosing specific sequences on the genome and optimizing the sgRNA and Cas9 can reduce the RNA-guided endonuclease off-target mutations. Cas13a is more efficient in recognizing the target region than Cas9 because it can recognize PFSs at the $3^{\prime}$ end with $3^{\prime} \mathrm{A}, 3^{\prime} \mathrm{U}$, or $3^{\prime} \mathrm{C}$ and the stem-loop structure made with $28 \mathrm{nt}$ direct repeats. However, this problem still lingers and is complex when editing complex genomes such as that for a human. A higher proportion of off-target mutations occur in humans than in lower animals. The delivery of sgRNA and Cas9 to the host cell stands as a constant challenge to the scientific community. Scientists have used plasmids, viruses, and ribonucleoproteins for delivery purposes, but the process also suffers from limitations [253].

AquAdvantage salmon developed by AquaBounty Technologies is the first genetically engineered animal approved for consumption by the USA in 2015 and by Canada in 2016. AquAdvantage salmon reached a market size in half-reduced time compared to wild fish [254]. Due to its universality, CRISPR will probability also be applied in animals to increase muscle mass, to reduce diseases, to improve vitality, etc. However, much more dangerous is the application of CRISPR to eradicate diseases by eradicating disease vectors and invasive species. One of the examples is Aedes aegypti, a mosquito that transmits dengue fever. Researchers are developing genetically edited male-sterile mosquitos to prevent reproduction, with an aim to reduce the spread of disease. However, these ambitions could result in the extinction of entire species, with unpredictable environmental consequences [255].

Another controversial topic associated with CRISPR-mediated modifications in plants and animals is gene drive technology. The first success in gene drive technology was accomplished in 2011, when a gene inserted into the mosquito genome spread through the population, reaching more than $85 \%$ of the insects' descendants. Gene drive is a genetic modification that is designed to spread through a population at higher-than-normal rates of inheritance. This CRISPR-based method alerts or silences a specific gene or inserts a new one. Gene drive actively copies a CRISPR-mediated mutation on one chromosome to its partner chromosome. This ensures that all offspring and the next generations will inherit the edited genome. Therefore, the application of gene drive in the environment possesses a much higher risk compared to genetically edited organisms, which has a $50 \%$ chance of inheriting the edited genes. Since 2014, scientists have engineered CRISPR-mediated gene drive systems in mosquitos, fruit flies, and fungi and are currently developing them in mice. No engineered gene drive organism has been released yet into the wild $[255,256]$.

One of the most discussed topics associated with CRISPR is human genome editing. The possibility of modifying human DNA is subject to intense debates in ethics and law. There are three main discussed problems: (i) risk and uncertainty of the technology and its application, (ii) the human germline interference and responsibility towards future generations, and (iii) the legitimization of human genome editing measures with regard to concepts of therapy and enhancement. Despite the mentioned problems also being associated with other genome editing techniques, the introduction of the CRISPR-Cas system has accelerated an effort to find adequate solutions. The assumption of risk associated with editing the human genome prompted many national regulators to restrict or ban their human applications, e.g., any artificial modification of germline cells is prohibited in Germany; similarly, the National Institutes of Health (NIH) in the USA decided not to fund any use of gene-editing technologies in human embryos. The criticism of human genome editing opponents is also increasing with the glory of CRISPR-Cas. Many of them argue that scientists are "playing God". Even the economic aspect is a bone of contention. Skeptics are afraid that CRISPR-Cas will become a beneficial technology only for rich people. In this unalluring scenario, a future society is divided into two main groups: the rich and healthy, and the poor and sick. Even if the uncertainty and risk associated with human genome editing could be minimized to an acceptable level, there are still several questions 
about whether it is ethically and legally justified to transfer these genetic modifications to future generations [257-259].

In therapeutics, CRISPR-Cas9 tools should be precisely and safely designed for longterm use. Human manipulation of genes that are passed on to organism via gene drive is risky and uncertain. The changes in the genome might lead to unknown changes undetected by any technology and may become a part of the human genome. Ethical concerns surround the use of CRISPR-Cas9 in humans and changing the descendant's genome in any way [187]. Some studies have shown that CRISPR-Cas9 activates TP53 overexpression through double-stranded breaks and leads to cell death [260]. Inactivation of TP53 through CRISPR-Cas9 can decrease cell death but will increase off-targets and carcinogenicity. There are two separate papers published on 11 June 2018 linking increased risk of cancer cell development with gene editing [260,261]. Simultaneously, Chinese researchers worked on the editing $H B B$ gene in nonviable embryos, producing mosaic embryo [262]. Among 86 embryos, approximately $82 \%$ of embryos survived and among which only 21 embryos were able to divide successfully but failed to show the desired genetic editing. In addition, the application of CRISPR-Cas9 in humans activates an immune response against Cas9, causing ill effects to the human body [114]. Researchers have modified the REC1 domain of Cas9, changing the epitope bound to T cell and thereby decreasing immune responses [263]. Recent reports on the advent of anti-CRISPR proteins project both opportunities and challenges in developing precise control over future CRISPRmediated gene edits via the inhibition of Cas9 binding on edited DNA [264].

The most dreading limitation or fear associated with the CRISPR-Cas system is the development of biological warfare. Gene-editing can genetically engineer the bacteria and viruses to be used in biological attacks against humans or to cause widespread crop damage $[265,266]$. Potential applications of gene editing technology emerge from CRISPR science and technology, raising serious concerns on biosecurity as a "double-edged sword". The potential nefarious biosecurity threats of CRISPR-mediated gene edits include the creation of novel neurotoxins/neuroweapons; virulence-enhanced de novo human and plant pathogens; increased human tolerance for soldiers against biological and chemical warfare; and bio-agents that cause human illness, degradation, disability, and lethality $[267,268]$. In comparison to the other genome/gene-editing technologies, CRISPR offers affordability, ease of use, and economical and extensive availability. Hence, the chances of misuse of these "weaponable entities" are also likely to be increased either by accident or by intentional and nefarious actors [267].

\section{Conclusions and Future Perspectives}

CRISPR-Cas is a sequence-specific nuclease able to edit the exact gene sequence, has revolutionized the field of biology, and has opened a new dimension in the field of genetic engineering and site-specific editing of nucleotide(s) within the malfunctioning gene. The tool's efficiency, robustness, and vastness in editing a large number of genes found important functions and traits in plant breeding, livestock improvement, and biomedical engineering. The technology has wide application in editing bacterial, fungal, and yeast strains for modifying the pathways in secondary metabolites qualitatively and quantitatively. Auroramycin, a lactam ring-containing antibiotic was obtained recently from Streptomyces roseosporus by using a CRISPR-Cas9 gene cluster activation strategy [216]. Medicinal bioactive compounds such as morphine, thebaine, and new alkaloid compounds are also being produced in opium poppy (Papaver somniferum L.) using Agrobacteriumfacilitated CRISPR-Cas via knockout genes [89].

Serious climatic effects have increased dependency on cleaner fuel. Microbial production of biofuels decreases the dependency on natural resources and is an environmentfriendly and economically efficient method of production. Advanced genome engineering methods such as CRISPR/Cas9 will optimize and improvise the bio-fuel production processes. Platform chemicals such as 3-methyl-1-butanol can be produced from renewable carbon source glucose directly by metabolically engineering industrially important Pichia 
pastoris [194]. Moreover, the use of CRISPR-Cas in hematologic diseases, infectious diseases, and malignant tumor via knockout, gene therapy, and gene editing has immense potential in therapeutics development (Figure 8).

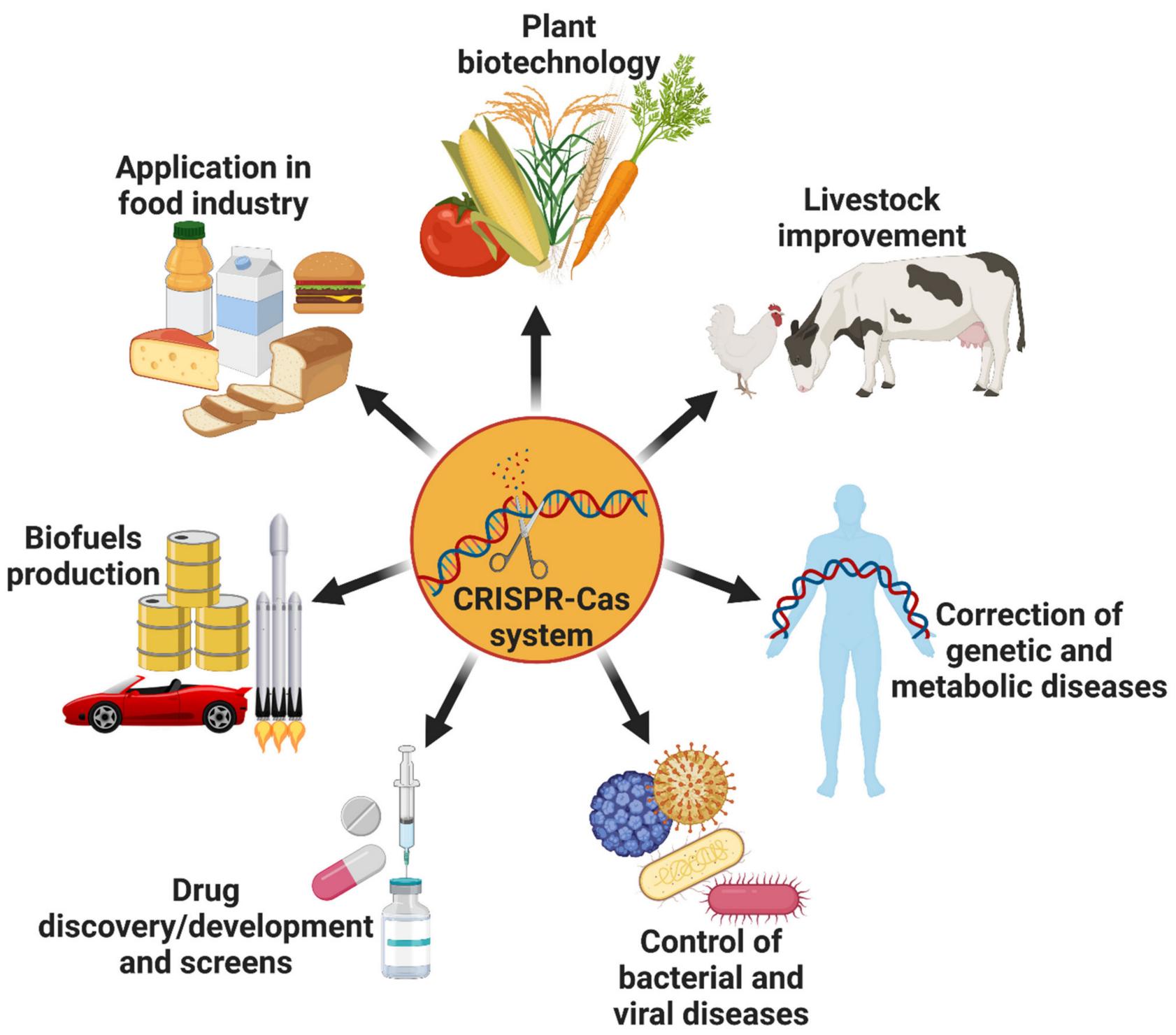

Figure 8. Applications of the CRISPR-Cas technology in various fields.

In conclusion, the CRISPR-Cas system is a unique technology for gene editing. Studies summarized in this review represent only the first steps in the CRISPR-Cas era of genetic engineering. Indeed, the CRISPR-Cas system brings high-quality, desired benefits like never before. Fields of application for this technology also appear to be limitless. CRISPR-Cas, a highly precise genome editing tool, allows us to improve our quality of life. Our food will become more nutrient-dense without the presence of toxins or pathogens. The CRISPR-mediated improvement of quality and quantity, and resistance to viruses, herbicides, drought, salt, and cold have already been reported in several crops. However, the technology will bring a completely new generation of crops including novel varieties. The CRISPR revolution will affect the production of biofuels, new materials, and more. The CRISPR technology also bears the potential to revive extinct species in the future and even to create completely new species. However, misuse of CRISPR-Cas for gene editing could be a risk and danger; therefore, ethical discussion about CRISPR in the scientific community is important. Despite all risks, we believe that the application of CRISPR is a 
great opportunity for humanity and that exact gene editing will bring us a bright future. An age of CRISPR has already started.

Author Contributions: S.N. literature survey, writing-original draft, table preparation, and reference collection; U.A. literature survey, writing — original draft, figure design, and reference arrangement; P.O. critical review and editing of the first draft, major figure preparation, revision and response, and reference arrangement; P.T. table preparation, review and editing, and improvement; J.A.L. overall reading, revision, and improvement and response; G.T. conceptualization, writing-review and editing, structure review, and supervision; K.K. writing-review and editing, visualization, response, suggestion, project administration, funding acquisition, and supervision; V.T. conceptualization, review and editing, response, review structure, and supervision. All authors have read and agreed to the published version of the manuscript.

Funding: This work was supported by UHK Project VT2019-2021.

Acknowledgments: The authors gratefully acknowledge Sam Higginbottom University of Agriculture, Technology, and Sciences (SHUATS), Prayagraj, India for providing the space and other necessary facilities that helped us to draft this manuscript.

Conflicts of Interest: The authors declare that they have no known competing financial interests or personal relationships that could have appeared to influence the work reported in this paper.

\section{References}

1. Ishino, Y.; Shinagawa, H.; Makino, K.; Amemura, M.; Nakata, A. Nucleotide sequence of the Iap gene, responsible for alkaline phosphatase isozyme conversion in Escherichia coli, and identification of the gene product. J. Bacteriol. 1987, 169, 5429-5433. [CrossRef] [PubMed]

2. Jore, M.M.; Brouns, S.J.J.; van der Oost, J. RNA in defense: CRISPRs protect prokaryotes against mobile genetic elements. Cold Spring Harb. Perspect. Biol. 2012, 4. [CrossRef]

3. Jansen, R.; van Embden, J.D.A.; Gaastra, W.; Schouls, L.M. Identification of genes that are associated with DNA repeats in prokaryotes. Mol. Microbiol. 2002, 43, 1565-1575. [CrossRef]

4. Mojica, F.J.; Juez, G.; Rodríguez-Valera, F. Transcription at different salinities of Haloferax mediterranei sequences adjacent to partially modified PstI sites. Mol. Microbiol. 1993, 9, 613-621. [CrossRef] [PubMed]

5. Makarova, K.S.; Aravind, L.; Grishin, N.V.; Rogozin, I.B.; Koonin, E.V. A DNA repair system specific for thermophilic Archaea and bacteria predicted by genomic context analysis. Nucleic Acids Res. 2002, 30, 482-496. [CrossRef]

6. Mojica, F.J.M.; Díez-Villaseñor, C.; García-Martínez, J.; Soria, E. Intervening sequences of regularly spaced prokaryotic repeats derive from foreign genetic elements. J. Mol. Evol. 2005, 60, 174-182. [CrossRef]

7. Pourcel, C.; Salvignol, G.; Vergnaud, G. CRISPR Elements in Yersinia pestis acquire new repeats by preferential uptake of bacteriophage DNA, and provide additional tools for evolutionary studies. Microbiology 2005, 151, 653-663. [CrossRef] [PubMed]

8. Makarova, K.S.; Grishin, N.V.; Shabalina, S.A.; Wolf, Y.I.; Koonin, E.V. A Putative RNA-interference-based immune system in prokaryotes: Computational analysis of the predicted enzymatic machinery, functional analogies with eukaryotic RNAi, and hypothetical mechanisms of action. Biol. Direct. 2006, 1, 7. [CrossRef]

9. Barrangou, R.; Fremaux, C.; Deveau, H.; Richards, M.; Boyaval, P.; Moineau, S.; Romero, D.A.; Horvath, P. CRISPR provides acquired resistance against viruses in prokaryotes. Science 2007, 315, 1709-1712. [CrossRef]

10. Makarova, K.S.; Haft, D.H.; Barrangou, R.; Brouns, S.J.J.; Charpentier, E.; Horvath, P.; Moineau, S.; Mojica, F.J.M.; Wolf, Y.I.; Yakunin, A.F.; et al. Evolution and classification of the CRISPR-cas systems. Nat. Rev. Microbiol. 2011, 9, 467-477. [CrossRef] [PubMed]

11. Sapranauskas, R.; Gasiunas, G.; Fremaux, C.; Barrangou, R.; Horvath, P.; Siksnys, V. The Streptococcus thermophilus CRISPR/cas system provides immunity in Escherichia Coli. Nucleic Acids Res. 2011, 39, 9275-9282. [CrossRef]

12. Bikard, D.; Jiang, W.; Samai, P.; Hochschild, A.; Zhang, F.; Marraffini, L.A. Programmable repression and activation of bacterial gene expression using an engineered CRISPR-cas system. Nucleic Acids Res. 2013, 41, 7429-7437. [CrossRef] [PubMed]

13. McGinn, J.; Marraffini, L.A. Molecular mechanisms of CRISPR-cas spacer acquisition. Nat. Rev. Microbiol. 2019, 17, 7-12. [CrossRef]

14. Makarova, K.S.; Wolf, Y.I.; Iranzo, J.; Shmakov, S.A.; Alkhnbashi, O.S.; Brouns, S.J.J.; Charpentier, E.; Cheng, D.; Haft, D.H.; Horvath, P.; et al. Evolutionary classification of CRISPR-cas systems: A burst of class 2 and derived variants. Nat. Rev. Microbiol. 2020, 18, 67-83. [CrossRef]

15. Hochstrasser, M.L.; Doudna, J.A. Cutting it close: CRISPR-associated endoribonuclease structure and function. Trends Biochem. Sci. 2015, 40, 58-66. [CrossRef] [PubMed]

16. Gleditzsch, D.; Pausch, P.; Müller-Esparza, H.; Özcan, A.; Guo, X.; Bange, G.; Randau, L. PAM identification by CRISPR-cas effector complexes: Diversified mechanisms and structures. RNA Biol. 2018, 16, 504-517. [CrossRef] [PubMed] 
17. Mojica, F.J.; Díez-Villaseñor, C.; Soria, E.; Juez, G. Biological significance of a family of regularly spaced repeats in the genomes of Archaea, Bacteria and Mitochondria. Mol. Microbiol. 2000, 36, 244-246. [CrossRef]

18. Karginov, F.V.; Hannon, G.J. The CRISPR system: Small RNA-guided defense in Bacteria and Archaea. Mol. Cell 2010, $37,7$. [CrossRef]

19. Alkhnbashi, O.S.; Shah, S.A.; Garrett, R.A.; Saunders, S.J.; Costa, F.; Backofen, R. Characterizing leader sequences of CRISPR loci. Bioinformatics 2016, 32, i576-i585. [CrossRef]

20. Makarova, K.S.; Wolf, Y.I.; Alkhnbashi, O.S.; Costa, F.; Shah, S.A.; Saunders, S.J.; Barrangou, R.; Brouns, S.J.J.; Charpentier, E.; Haft, D.H.; et al. An updated evolutionary classification of CRISPR-cas systems. Nat. Rev. Microb. 2015, 13, 722-736. [CrossRef]

21. Clark, D.P.; Pazdernik, N.J.; McGehee, M.R. Chapter 20-Genome Defense. In Molecular Biology, 3rd ed.; Clark, D.P., Pazdernik, N.J., McGehee, M.R., Eds.; Elsevier: Amsterdam, The Netherlands, 2019; pp. 622-653. ISBN 978-0-12-813288-3.

22. Charpentier, E.; Richter, H.; van der Oost, J.; White, M.F. Biogenesis pathways of RNA guides in Archaeal and Bacterial CRISPR-cas adaptive immunity. FEMS Microbiol. Rev. 2015, 39, 428-441. [CrossRef] [PubMed]

23. Özcan, A.; Pausch, P.; Linden, A.; Wulf, A.; Schühle, K.; Heider, J.; Urlaub, H.; Heimerl, T.; Bange, G.; Randau, L. Type IV CRISPR RNA processing and effector complex formation in Aromatoleum aromaticum. Nat. Microbiol. 2019, 4, 89-96. [CrossRef] [PubMed]

24. Hille, F.; Richter, H.; Wong, S.P.; Bratovič, M.; Ressel, S.; Charpentier, E. The biology of CRISPR-cas: Backward and forward. Cell 2018, 172, 1239-1259. [CrossRef]

25. Zhou, Y.; Bravo, J.P.K.; Taylor, H.N.; Steens, J.; Jackson, R.N.; Staals, R.H.J.; Taylor, D.W. Structure of a type IV CRISPR-cas effector complex. bioRxiv 2020. [CrossRef]

26. Schindele, P.; Wolter, F.; Puchta, H. Transforming plant biology and breeding with CRISPR/Cas9, Cas12 and Cas13. FEBS Lett. 2018, 592, 1954-1967. [CrossRef]

27. Jinek, M.; Chylinski, K.; Fonfara, I.; Hauer, M.; Doudna, J.A.; Charpentier, E. A programmable dual-RNA-guided DNA endonuclease in adaptive bacterial immunity. Science 2012, 337, 816-821. [CrossRef]

28. Li, Y.; Glass, Z.; Huang, M.; Chen, Z.-Y.; Xu, Q. Ex vivo cell-based CRISPR/Cas9 genome editing for therapeutic applications. Biomaterials 2020, 234, 119711. [CrossRef]

29. Rees, H.A.; Liu, D.R. Base editing: Precision chemistry on the genome and transcriptome of living cells. Nat. Rev. Genet. 2018, 19, 770-788. [CrossRef]

30. Miao, J.; Guo, D.; Zhang, J.; Huang, Q.; Qin, G.; Zhang, X.; Wan, J.; Gu, H.; Qu, L.-J. Targeted mutagenesis in rice using CRISPR-cas system. Cell Res. 2013, 23, 1233-1236. [CrossRef]

31. Shan, Q.; Wang, Y.; Li, J.; Gao, C. Genome editing in rice and wheat using the CRISPR/cas system. Nat. Protoc. 2014, 9, 2395-2410. [CrossRef] [PubMed]

32. Zhang, Y.; Li, D.; Zhang, D.; Zhao, X.; Cao, X.; Dong, L.; Liu, J.; Chen, K.; Zhang, H.; Gao, C.; et al. Analysis of the functions of TaGW2 homoeologs in wheat grain weight and protein content traits. Plant J. 2018, 94, 857-866. [CrossRef]

33. Ma, X.; Zhang, Q.; Zhu, Q.; Liu, W.; Chen, Y.; Qiu, R.; Wang, B.; Yang, Z.; Li, H.; Lin, Y.; et al. A Robust CRISPR/Cas9 system for convenient, high-efficiency multiplex genome editing in monocot and dicot plants. Mol. Plant 2015, 8, 1274-1284. [CrossRef] [PubMed]

34. Jiang, W.Z.; Henry, I.M.; Lynagh, P.G.; Comai, L.; Cahoon, E.B.; Weeks, D.P. Significant enhancement of fatty acid composition in seeds of the allohexaploid, cCamelina sativa, using CRISPR/Cas9 gene editing. Plant Biotechnol. J. 2017, 15, 648-657. [CrossRef] [PubMed]

35. Sánchez-León, S.; Gil-Humanes, J.; Ozuna, C.V.; Giménez, M.J.; Sousa, C.; Voytas, D.F.; Barro, F. Low-gluten, nontransgenic wheat engineered with CRISPR/Cas9. Plant Biotechnol. J. 2018, 16, 902-910. [CrossRef] [PubMed]

36. Aznar-Moreno, J.A.; Durrett, T.P. Simultaneous targeting of multiple gene homeologs to alter seed oil production in Camelina sativa. Plant Cell Physiol. 2017, 58, 1260-1267. [CrossRef]

37. Sun, Y.; Jiao, G.; Liu, Z.; Zhang, X.; Li, J.; Guo, X.; Du, W.; Du, J.; Francis, F.; Zhao, Y.; et al. Generation of high-amylose rice through CRISPR/Cas9-mediated targeted mutagenesis of starch branching enzymes. Front. Plant Sci. 2017, 8. [CrossRef] [PubMed]

38. Shan, Q.; Wang, Y.; Li, J.; Zhang, Y.; Chen, K.; Liang, Z.; Zhang, K.; Liu, J.; Xi, J.J.; Qiu, J.-L.; et al. Targeted genome modification of crop plants using a CRISPR-cas system. Nat. Biotechnol. 2013, 31, 686-688. [CrossRef]

39. Klap, C.; Yeshayahou, E.; Bolger, A.M.; Arazi, T.; Gupta, S.K.; Shabtai, S.; Usadel, B.; Salts, Y.; Barg, R. Tomato facultative parthenocarpy results from SIAGAMOUS-LIKE 6 loss of function. Plant Biotechnol. J. 2017, 15, 634-647. [CrossRef] [PubMed]

40. Lu, H.-P.; Luo, T.; Fu, H.-W.; Wang, L.; Tan, Y.-Y.; Huang, J.-Z.; Wang, Q.; Ye, G.-Y.; Gatehouse, A.M.R.; Lou, Y.-G.; et al. Resistance of Rice to Insect Pests Mediated by Suppression of Serotonin Biosynthesis. Nat. Plants 2018, 4, 338-344. [CrossRef]

41. Christian, M.; Cermak, T.; Doyle, E.L.; Schmidt, C.; Zhang, F.; Hummel, A.; Bogdanove, A.J.; Voytas, D.F. Targeting DNA Double-Strand Breaks with TAL Effector Nucleases. Genetics 2010, 186, 757-761. [CrossRef]

42. Chen, K.; Wang, Y.; Zhang, R.; Zhang, H.; Gao, C. CRISPR/Cas genome editing and precision plant breeding in agriculture. Annu. Rev. Plant Biol. 2019, 70, 667-697. [CrossRef]

43. Kim, H.; Kim, S.-T.; Ryu, J.; Kang, B.-C.; Kim, J.-S.; Kim, S.-G. CRISPR/Cpf1-mediated DNA-free plant genome editing. Nat. Commun. 2017, 8, 14406. [CrossRef] [PubMed]

44. Xu, R.; Li, H.; Qin, R.; Wang, L.; Li, L.; Wei, P.; Yang, J. Gene targeting using the Agrobacterium Ttumefaciens-mediated CRISPR-cas system in rice. Rice 2014, 7, 5. [CrossRef] 
45. Yin, K.; Han, T.; Liu, G.; Chen, T.; Wang, Y.; Yu, A.Y.L.; Liu, Y. A Geminivirus-based guide RNA delivery system for CRISPR/Cas9 mediated plant genome editing. Sci. Rep. 2015, 5, 14926. [CrossRef] [PubMed]

46. Baltes, N.J.; Hummel, A.W.; Konecna, E.; Cegan, R.; Bruns, A.N.; Bisaro, D.M.; Voytas, D.F. Conferring resistance to geminiviruses with the CRISPR-cas prokaryotic immune System. Nat. Plants 2015, 1, 15145. [CrossRef]

47. Feng, Z.; Mao, Y.; Xu, N.; Zhang, B.; Wei, P.; Yang, D.-L.; Wang, Z.; Zhang, Z.; Zheng, R.; Yang, L.; et al. Multigeneration analysis reveals the inheritance, specificity, and patterns of CRISPR/cas-induced gene modifications in arabidopsis. Proc. Natl. Acad. Sci. USA 2014, 111, 4632-4637. [CrossRef] [PubMed]

48. Puchta, H. Using CRISPR/cas in three dimensions: Towards synthetic plant genomes, transcriptomes and epigenomes. Plant J. 2016, 87, 5-15. [CrossRef]

49. Aman, R.; Ali, Z.; Butt, H.; Mahas, A.; Aljedaani, F.; Khan, M.Z.; Ding, S.; Mahfouz, M. RNA Virus interference via CRISPR/Cas13a system in plants. Genome Biol. 2018, 19, 1. [CrossRef]

50. Abudayyeh, O.O.; Gootenberg, J.S.; Essletzbichler, P.; Han, S.; Joung, J.; Belanto, J.J.; Verdine, V.; Cox, D.B.T.; Kellner, M.J.; Regev, A.; et al. RNA targeting with CRISPR-Cas13. Nature 2017, 550, 280-284. [CrossRef]

51. Zhou, H.; He, M.; Li, J.; Chen, L.; Huang, Z.; Zheng, S.; Zhu, L.; Ni, E.; Jiang, D.; Zhao, B.; et al. Development of commercial thermo-sensitive genic male sterile rice accelerates hybrid rice breeding using the CRISPR/Cas9-Mediated TMS5 editing system. Sci. Rep. 2016, 6, 37395. [CrossRef]

52. Svitashev, S.; Schwartz, C.; Lenderts, B.; Young, J.K.; Mark Cigan, A. Genome editing in maize directed by CRISPR-Cas9 ribonucleoprotein complexes. Nat. Commun. 2016, 7, 13274. [CrossRef]

53. Singh, M.; Kumar, M.; Albertsen, M.C.; Young, J.K.; Cigan, A.M. Concurrent modifications in the three homeologs of Ms45 gene with CRISPR-Cas9 lead to rapid generation of male sterile bread wheat (Triticum Aaestivum, L.). Plant. Mol. Biol. 2018, 97, 371-383. [CrossRef]

54. Yao, L.; Zhang, Y.; Liu, C.; Liu, Y.; Wang, Y.; Liang, D.; Liu, J.; Sahoo, G.; Kelliher, T. OsMATL mutation induces haploid seed formation in indica rice. Nat. Plants 2018, 4, 530-533. [CrossRef] [PubMed]

55. Shimatani, Z.; Kashojiya, S.; Takayama, M.; Terada, R.; Arazoe, T.; Ishii, H.; Teramura, H.; Yamamoto, T.; Komatsu, H.; Miura, K.; et al. Targeted base editing in rice and tomato using a CRISPR-Cas9 cytidine deaminase fusion. Nat. Biotechnol. 2017, 35, 441-443. [CrossRef] [PubMed]

56. Chen, Y.; Wang, Z.; Ni, H.; Xu, Y.; Chen, Q.; Jiang, L. CRISPR/Cas9-mediated base-editing system efficiently generates gain-offunction mutations in arabidopsis. Sci. China Life Sci. 2017, 60, 520-523. [CrossRef]

57. Tian, S.; Jiang, L.; Cui, X.; Zhang, J.; Guo, S.; Li, M.; Zhang, H.; Ren, Y.; Gong, G.; Zong, M.; et al. Engineering herbicide-resistant watermelon variety through CRISPR/Cas9-mediated base-editing. Plant Cell Rep. 2018, 37, 1353-1356. [CrossRef] [PubMed]

58. Malnoy, M.; Viola, R.; Jung, M.-H.; Koo, O.-J.; Kim, S.; Kim, J.-S.; Velasco, R.; Nagamangala Kanchiswamy, C. DNA-free genetically edited grapevine and apple protoplast using CRISPR/Cas9 ribonucleoproteins. Front. Plant Sci. 2016, 7, 1904. [CrossRef] [PubMed]

59. Ji, L.; Jordan, W.T.; Shi, X.; Hu, L.; He, C.; Schmitz, R.J. TET-mediated epimutagenesis of the Arabidopsis thaliana methylome. Nat. Commun. 2018, 9, 895. [CrossRef]

60. Tripathi, L.; Ntui, V.O.; Tripathi, J.N. CRISPR/Cas9-based genome editing of banana for disease resistance. Curr. Opin. Plant Biol. 2020, 56, 118-126. [CrossRef]

61. Gomez, M.A.; Lin, Z.D.; Moll, T.; Luebbert, C.; Chauhan, R.D.; Vijayaraghavan, A.; Kelley, R.; Beyene, G.; Taylor, N.J.; Carrington, J.; et al. Simultaneous CRISPR/Cas9-mediated editing of cassava EIF4E isoforms NCBP-1 and NCBP-2 confers elevated resistance to cassava brown streak disease. bioRxiv 2017, 209874. [CrossRef]

62. Hummel, A.W.; Chauhan, R.D.; Cermak, T.; Mutka, A.M.; Vijayaraghavan, A.; Boyher, A.; Starker, C.G.; Bart, R.; Voytas, D.F.; Taylor, N.J. Allele exchange at the EPSPS locus confers glyphosate tolerance in cassava. Plant Biotechnol. J. 2018, 16, 1275-1282. [CrossRef]

63. Peng, A.; Chen, S.; Lei, T.; Xu, L.; He, Y.; Wu, L.; Yao, L.; Zou, X. Engineering canker-resistant plants through CRISPR/Cas9targeted editing of the susceptibility gene CsLOB1 promoter in citrus. Plant Biotechnol. J. 2017, 15, 1509-1519. [CrossRef]

64. Jia, H.; Zhang, Y.; Orbović, V.; Xu, J.; White, F.F.; Jones, J.B.; Wang, N. Genome editing of the disease susceptibility gene CsLOB1 in citrus confers resistance to citrus canker. Plant Biotechnol. J. 2017, 15, 817-823. [CrossRef]

65. Fister, A.S.; Landherr, L.; Maximova, S.N.; Guiltinan, M.J. Transient expression of CRISPR/Cas9 machinery targeting TcNPR3 enhances defense response in theobroma cacao. Front. Plant Sci. 2018, 9, 268. [CrossRef]

66. Iqbal, Z.; Sattar, M.N.; Shafiq, M. CRISPR/Cas9: A tool to circumscribe cotton leaf curl disease. Front. Plant Sci. 2016, 7. [CrossRef]

67. Zhang, Z.; Ge, X.; Luo, X.; Wang, P.; Fan, Q.; Hu, G.; Xiao, J.; Li, F.; Wu, J. Simultaneous editing of two copies of Gh14-3-3d confers enhanced transgene-clean plant defense against Verticillium Dahliae in allotetraploid upland cotton. Front. Plant Sci. 2018, 9. [CrossRef] [PubMed]

68. Chandrasekaran, J.; Brumin, M.; Wolf, D.; Leibman, D.; Klap, C.; Pearlsman, M.; Sherman, A.; Arazi, T.; Gal-On, A. Development of broad virus resistance in non-transgenic cucumber using CRISPR/Cas9 technology. Mol. Plant Pathol. 2016, 17, 1140-1153. [CrossRef] [PubMed]

69. Sauer, N.J.; Narváez-Vásquez, J.; Mozoruk, J.; Miller, R.B.; Warburg, Z.J.; Woodward, M.J.; Mihiret, Y.A.; Lincoln, T.A.; Segami, R.E.; Sanders, S.L.; et al. Oligonucleotide-mediated genome editing provides precision and function to engineered nucleases and antibiotics in plants. Plant Physiol. 2016, 170, 1917-1928. [CrossRef] [PubMed] 
70. Wang, X.; Guo, R.; Tu, M.; Wang, D.; Guo, C.; Wan, R.; Li, Z.; Wang, X. Ectopic expression of the wild grape WRKY transcription factor VqWRKY52 in Arabidopsis thaliana enhances resistance to the biotrophic pathogen powdery mildew but not to the necrotrophic pathogen Botrytis cinerea. Front. Plant Sci. 2017, 8. [CrossRef]

71. Choudhury, M.D.; Das, S.; Tarafdar, S. Effect of loading history on visco-elastic potato starch Gel. Coll. Surf. A Physicochem. Eng. Asp. 2016, 492, 47-53. [CrossRef]

72. Makhotenko, A.V.; Khromov, A.V.; Snigir, E.A.; Makarova, S.S.; Makarov, V.V.; Suprunova, T.P.; Kalinina, N.O.; Taliansky, M.E. Functional analysis of coilin in virus resistance and stress tolerance of potato Solanum tuberosum using CRISPR-Cas9 editing. Dokl. Biochem. Biophys. 2019, 484, 88-91. [CrossRef]

73. Ma, J.; Chen, J.; Wang, M.; Ren, Y.; Wang, S.; Lei, C.; Cheng, Z. Sodmergen, null disruption of OsSEC3A increases the content of salicylic acid and induces plant defense responses in rice. J. Exp. Bot. 2018, 69, 1051-1064. [CrossRef] [PubMed]

74. Macovei, A.; Sevilla, N.R.; Cantos, C.; Jonson, G.B.; Slamet-Loedin, I.; Čermák, T.; Voytas, D.F.; Choi, I.-R.; Chadha-Mohanty, P. Novel alleles of rice EIF4G generated by CRISPR/Cas9-targeted mutagenesis confer resistance to rice tungro spherical virus. Plant Biotechnol. J. 2018, 16, 1918-1927. [CrossRef] [PubMed]

75. Li, J.; Meng, X.; Zong, Y.; Chen, K.; Zhang, H.; Liu, J.; Li, J.; Gao, C. Gene replacements and insertions in rice by intron targeting using CRISPR-Cas9. Nat. Plants 2016, 2, 16139. [CrossRef]

76. Mishra, R.; Joshi, R.K.; Zhao, K. Genome editing in rice: Recent advances, challenges, and future implications. Front. Plant Sci. 2018, 9. [CrossRef]

77. Cai, Y.; Chen, L.; Liu, X.; Sun, S.; Wu, C.; Jiang, B.; Han, T.; Hou, W. CRISPR/Cas9-mediated genome editing in soybean hairy roots. PLoS ONE 2015, 10, e0136064. [CrossRef]

78. Ludman, M.; Burgyán, J.; Fátyol, K. Crispr/Cas9 mediated inactivation of argonaute 2 reveals its differential involvement in antiviral responses. Sci. Rep. 2017, 7, 1010. [CrossRef] [PubMed]

79. Nekrasov, V.; Wang, C.; Win, J.; Lanz, C.; Weigel, D.; Kamoun, S. Rapid generation of a transgene-free powdery mildew resistant tomato by genome deletion. Sci. Rep. 2017, 7, 482. [CrossRef]

80. Ortigosa, A.; Gimenez-Ibanez, S.; Leonhardt, N.; Solano, R. Design of a bacterial speck resistant tomato by CRISPR/Cas9-mediated editing of SlJAZ2. Plant Biotechnol. J. 2019, 17, 665-673. [CrossRef]

81. Zhang, Y.; Bai, Y.; Wu, G.; Zou, S.; Chen, Y.; Gao, C.; Tang, D. Simultaneous modification of three homoeologs of TaEDR1 by genome editing enhances powdery mildew resistance in wheat. Plant J. 2017, 91, 714-724. [CrossRef]

82. Acevedo-Garcia, J.; Spencer, D.; Thieron, H.; Reinstädler, A.; Hammond-Kosack, K.; Phillips, A.L.; Panstruga, R. Mlo-based powdery mildew resistance in hexaploid bread wheat generated by a non-transgenic TILLING approach. Plant Biotechnol. J. 2017, 15, 367-378. [CrossRef] [PubMed]

83. Li, W.; Nguyen, K.H.; Chu, H.D.; Ha, C.V.; Watanabe, Y.; Osakabe, Y.; Leyva-González, M.A.; Sato, M.; Toyooka, K.; Voges, L.; et al. The karrikin receptor KAI2 promotes drought resistance in Arabidopsis thaliana. PLoS Genet. 2017, 13, e1007076. [CrossRef]

84. Kapusi, E.; Corcuera-Gómez, M.; Melnik, S.; Stoger, E. Heritable Genomic fragment deletions and small indels in the putative ENGase gene induced by CRISPR/Cas9 in barley. Front. Plant Sci. 2017, 8, 540. [CrossRef] [PubMed]

85. Ren, C.; Liu, X.; Zhang, Z.; Wang, Y.; Duan, W.; Li, S.; Liang, Z. CRISPR/Cas9-mediated efficient targeted mutagenesis in chardonnay (Vitis Vinifera, L.). Sci. Rep. 2016, 6, 32289. [CrossRef] [PubMed]

86. Wang, L.; Wang, L.; Tan, Q.; Fan, Q.; Zhu, H.; Hong, Z.; Zhang, Z.; Duanmu, D. Efficient inactivation of symbiotic nitrogen fixation related genes in Lotus japonicus using CRISPR-Cas9. Front. Plant Sci. 2016, 7, 1333. [CrossRef]

87. Zuo, Y.; Feng, F.; Qi, W.; Song, R. Dek42 encodes an RNA-binding protein that affects alternative Pre-MRNA splicing and maize kernel development. J. Integr. Plant Biol. 2019, 61, 728-748. [CrossRef] [PubMed]

88. Waltz, E. CRISPR-edited crops free to enter market, skip regulation. Nat. Biotechnol. 2016, 34, 582. [CrossRef]

89. Alagoz, Y.; Gurkok, T.; Zhang, B.; Unver, T. Manipulating the biosynthesis of bioactive compound alkaloids for next-generation metabolic engineering in opium poppy using CRISPR-Cas 9 genome editing technology. Sci. Rep. 2016, 6, 30910. [CrossRef]

90. Kui, L.; Chen, H.; Zhang, W.; He, S.; Xiong, Z.; Zhang, Y.; Yan, L.; Zhong, C.; He, F.; Chen, J.; et al. Building a genetic manipulation tool box for orchid biology: Identification of constitutive promoters and application of CRISPR/Cas9 in the orchid, Dendrobium officinale. Front. Plant Sci. 2017, 7. [CrossRef]

91. Semiarti, E.; Nopitasari, S.; Setiawati, Y.; Lawrie, M.D.; Purwantoro, A.; Widada, J.; Yoshioka, Y.; Matsumoto, S.; Ninomiya, K.; Asano, Y. Application of CRISPR/Cas9 genome editing system for molecular breeding of orchids. Indones. J. Biotechnol. 2020, 25, 61-68. [CrossRef]

92. Andersson, M.; Turesson, H.; Nicolia, A.; Fält, A.-S.; Samuelsson, M.; Hofvander, P. Efficient targeted multiallelic mutagenesis in tetraploid potato (Solanum Ttuberosum) by transient CRISPR-Cas9 expression in protoplasts. Plant. Cell Rep. 2017, 36, 117-128. [CrossRef]

93. Zhou, X.; Zha, M.; Huang, J.; Li, L.; Imran, M.; Zhang, C. StMYB44 negatively regulates phosphate transport by suppressing expression of PHOSPHATE1 in potato. J. Exp. Bot. 2017, 68, 1265-1281. [CrossRef] [PubMed]

94. Veillet, F.; Perrot, L.; Chauvin, L.; Kermarrec, M.-P.; Guyon-Debast, A.; Chauvin, J.-E.; Nogué, F.; Mazier, M. Transgene-free genome editing in tomato and potato plants using agrobacterium-mediated delivery of a CRISPR/Cas9 cytidine base editor. Int. J. Mol. Sci. 2019, 20, 402. [CrossRef]

95. Li, M.; Li, X.; Zhou, Z.; Wu, P.; Fang, M.; Pan, X.; Lin, Q.; Luo, W.; Wu, G.; Li, H. Reassessment of the four yield-related genes Gn1a, DEP1, GS3, and IPA1 in rice using a CRISPR/Cas9 system. Front. Plant Sci. 2016, 7. [CrossRef] 
96. Xu, R.; Yang, Y.; Qin, R.; Li, H.; Qiu, C.; Li, L.; Wei, P.; Yang, J. Rapid improvement of grain weight via highly efficient CRISPR/Cas9-mediated multiplex genome editing in rice. J. Genet. Genom. 2016, 43, 529-532. [CrossRef] [PubMed]

97. Zhang, H.; Zhang, J.; Wei, P.; Zhang, B.; Gou, F.; Feng, Z.; Mao, Y.; Yang, L.; Zhang, H.; Xu, N.; et al. The CRISPR/Cas9 system produces specific and homozygous targeted gene editing in rice in one generation. Plant Biotechnol. J. 2014, 12, 797-807. [CrossRef] [PubMed]

98. Nieves-Cordones, M.; Mohamed, S.; Tanoi, K.; Kobayashi, N.I.; Takagi, K.; Vernet, A.; Guiderdoni, E.; Périn, C.; Sentenac, H.; Véry, A.-A. Production of low-Cs+ rice plants by inactivation of the $\mathrm{K}+$ transporter OsHAK1 with the CRISPR-cas system. Plant J. 2017, 92, 43-56. [CrossRef] [PubMed]

99. Mao, X.; Zheng, Y.; Xiao, K.; Wei, Y.; Zhu, Y.; Cai, Q.; Chen, L.; Xie, H.; Zhang, J. OsPRX2 contributes to stomatal closure and improves potassium deficiency tolerance in rice. Biochem. Biophys. Res. Commun. 2018, 495, 461-467. [CrossRef]

100. Shen, C.; Que, Z.; Xia, Y.; Tang, N.; Li, D.; He, R.; Cao, M. Knock out of the annexin gene OsAnn3 via CRISPR/Cas9-mediated genome editing decreased cold tolerance in rice. J. Plant Biol. 2017, 60, 539-547. [CrossRef]

101. Li, C.; Zong, Y.; Wang, Y.; Jin, S.; Zhang, D.; Song, Q.; Zhang, R.; Gao, C. Expanded base editing in rice and wheat using a Cas9-adenosine deaminase fusion. Genome Biol. 2018, 19, 59. [CrossRef]

102. Iaffaldano, B.; Zhang, Y.; Cornish, K. CRISPR/Cas9 genome editing of rubber producing dandelion Taraxacum kok-saghyz using Agrobacterium rhizogenes without selection. Ind. Crops Prod. 2016, 89, 356-362. [CrossRef]

103. Bao, A.; Chen, H.; Chen, L.; Chen, S.; Hao, Q.; Guo, W.; Qiu, D.; Shan, Z.; Yang, Z.; Yuan, S.; et al. CRISPR/Cas9-mediated targeted mutagenesis of GmSPL9 genes alters plant architecture in soybean. BMC Plant Biol. 2019, 19, 131. [CrossRef]

104. Ueta, R.; Abe, C.; Watanabe, T.; Sugano, S.S.; Ishihara, R.; Ezura, H.; Osakabe, Y.; Osakabe, K. Rapid breeding of parthenocarpic tomato plants using CRISPR/Cas9. Sci. Rep. 2017, 7, 507. [CrossRef]

105. Ito, Y.; Nishizawa-Yokoi, A.; Endo, M.; Mikami, M.; Toki, S. CRISPR/Cas9-mediated mutagenesis of the RIN locus that regulates tomato fruit ripening. Biochem. Biophys. Res. Commun. 2015, 467, 76-82. [CrossRef] [PubMed]

106. Wang, R.; Tavano, E.C.D.R.; Lammers, M.; Martinelli, A.P.; Angenent, G.C.; de Maagd, R.A. Re-evaluation of transcription factor function in tomato fruit development and ripening with CRISPR/Cas9-mutagenesis. Sci. Rep. 2019, 9, 1696. [CrossRef]

107. Brooks, C.; Nekrasov, V.; Lippman, Z.B.; Van Eck, J. Efficient gene editing in tomato in the first generation using the clustered regularly interspaced short palindromic repeats/CRISPR-associated9 system1. Plant Physiol. 2014, 166, 1292-1297. [CrossRef]

108. Li, R.; Liu, C.; Zhao, R.; Wang, L.; Chen, L.; Yu, W.; Zhang, S.; Sheng, J.; Shen, L. CRISPR/Cas9-mediated SINPR1 mutagenesis reduces tomato plant drought tolerance. BMC Plant Biol. 2019, 19, 38. [CrossRef]

109. Zhang, S.; Zhang, R.; Song, G.; Gao, J.; Li, W.; Han, X.; Chen, M.; Li, Y.; Li, G. Targeted mutagenesis using the Agrobacterium tumefaciens-mediated CRISPR-Cas9 system in common wheat. BMC Plant Biol. 2018, 18, 302. [CrossRef]

110. Liu, H.; Wang, K.; Jia, Z.; Gong, Q.; Lin, Z.; Du, L.; Pei, X.; Ye, X. Efficient induction of haploid plants in wheat by editing of TaMTL using an optimized agrobacterium-mediated CRISPR System. J. Exp. Bot. 2020, 71, 1337-1349. [CrossRef] [PubMed]

111. Von Caemmerer, S.; Quick, W.P.; Furbank, R.T. The development of C4 rice: Current progress and future challenges. Science 2012, 336, 1671-1672. [CrossRef] [PubMed]

112. Salesse-Smith, C.E.; Sharwood, R.E.; Busch, F.A.; Kromdijk, J.; Bardal, V.; Stern, D.B. Overexpression of rubisco subunits with RAF1 increases rubisco content in maize. Nat. Plants 2018, 4, 802-810. [CrossRef]

113. Li, T.; Yang, X.; Yu, Y.; Si, X.; Zhai, X.; Zhang, H.; Dong, W.; Gao, C.; Xu, C. Domestication of wild tomato is accelerated by genome editing. Nat. Biotechnol. 2018. [CrossRef]

114. Kosicki, M.; Tomberg, K.; Bradley, A. Repair of double-strand breaks induced by CRISPR-Cas9 leads to large deletions and complex rearrangements. Nat. Biotechnol. 2018, 36, 765-771. [CrossRef]

115. Khan, M.Z.; Amin, I.; Hameed, A.; Mansoor, S. CRISPR-Cas13a: Prospects for plant virus resistance. Trends Biotechnol. 2018, 36, 1207-1210. [CrossRef]

116. Min, Y.-L.; Li, H.; Rodriguez-Caycedo, C.; Mireault, A.A.; Huang, J.; Shelton, J.M.; McAnally, J.R.; Amoasii, L.; Mammen, P.P.A.; Bassel-Duby, R.; et al. CRISPR-Cas9 corrects duchenne muscular dystrophy exon 44 deletion mutations in mice and human cells. Sci. Adv. 2019, 5, eaav4324. [CrossRef] [PubMed]

117. Bjursell, M.; Porritt, M.J.; Ericson, E.; Taheri-Ghahfarokhi, A.; Clausen, M.; Magnusson, L.; Admyre, T.; Nitsch, R.; Mayr, L.; Aasehaug, L.; et al. Therapeutic genome editing with CRISPR/Cas9 in a humanized mouse model ameliorates A1-antitrypsin deficiency phenotype. EBioMedicine 2018, 29, 104-111. [CrossRef] [PubMed]

118. Ohmori, T.; Mizukami, H.; Ozawa, K.; Sakata, Y.; Nishimura, S. New approaches to gene and cell therapy for hemophilia. J. Thromb. Haemost. 2015, 13, S133-S142. [CrossRef]

119. Khosravi, M.A.; Abbasalipour, M.; Concordet, J.-P.; Berg, J.V.; Zeinali, S.; Arashkia, A.; Azadmanesh, K.; Buch, T.; Karimipoor, M. Targeted deletion of BCL11A gene by CRISPR-Cas9 system for fetal hemoglobin reactivation: A promising approach for gene therapy of beta thalassemia disease. Eur. J. Pharmacol. 2019, 854, 398-405. [CrossRef] [PubMed]

120. György, B.; Nist-Lund, C.; Pan, B.; Asai, Y.; Karavitaki, K.D.; Kleinstiver, B.P.; Garcia, S.P.; Zaborowski, M.P.; Solanes, P.; Spataro, S.; et al. Allele-specific gene editing prevents deafness in a model of dominant progressive hearing loss. Nat. Med. 2019, 25, 1123-1130. [CrossRef]

121. Dever, D.P.; Bak, R.O.; Reinisch, A.; Camarena, J.; Washington, G.; Nicolas, C.E.; Pavel-Dinu, M.; Saxena, N.; Wilkens, A.B.; Mantri, S.; et al. CRISPR/Cas9 $\beta$-globin gene targeting in human haematopoietic stem cells. Nature 2016, 539, 384-389. [CrossRef] [PubMed] 
122. Isgrò, A.; Gaziev, J.; Sodani, P.; Lucarelli, G. Progress in hematopoietic stem cell transplantation as allogeneic cellular gene therapy in thalassemia. Ann. N. Y. Acad. Sci. 2010, 1202, 149-154. [CrossRef] [PubMed]

123. Traylen, C.M.; Patel, H.R.; Fondaw, W.; Mahatme, S.; Williams, J.F.; Walker, L.R.; Dyson, O.F.; Arce, S.; Akula, S.M. Virus reactivation: A panoramic view in human infections. Future Virol. 2011, 6, 451-463. [CrossRef] [PubMed]

124. Craigie, R.; Bushman, F.D. HIV DNA integration. Cold Spring Harb. Perspect. Med. 2012, 2, a006890. [CrossRef]

125. Finzi, D.; Blankson, J.; Siliciano, J.D.; Margolick, J.B.; Chadwick, K.; Pierson, T.; Smith, K.; Lisziewicz, J.; Lori, F.; Flexner, C.; et al. Latent infection of CD4+ T cells provides a mechanism for lifelong persistence of HIV-1, even in patients on effective combination therapy. Nat. Med. 1999, 5, 512-517. [CrossRef] [PubMed]

126. Hu, W.; Kaminski, R.; Yang, F.; Zhang, Y.; Cosentino, L.; Li, F.; Luo, B.; Alvarez-Carbonell, D.; Garcia-Mesa, Y.; Karn, J.; et al. RNA-directed gene editing specifically eradicates latent and prevents new HIV-1 infection. Proc. Natl. Acad. Sci. USA 2014, 111, 11461-11466. [CrossRef]

127. Cho, S.W.; Kim, S.; Kim, J.M.; Kim, J.-S. Targeted genome engineering in human cells with the Cas9 RNA-guided endonuclease. Nat. Biotechnol. 2013, 31, 230-232. [CrossRef]

128. Hou, P.; Chen, S.; Wang, S.; Yu, X.; Chen, Y.; Jiang, M.; Zhuang, K.; Ho, W.; Hou, W.; Huang, J.; et al. Genome editing of CXCR4 by CRISPR/Cas9 confers cells resistant to HIV-1 infection. Sci. Rep. 2015, 5, 15577. [CrossRef]

129. Liu, Z.; Chen, S.; Jin, X.; Wang, Q.; Yang, K.; Li, C.; Xiao, Q.; Hou, P.; Liu, S.; Wu, S.; et al. Genome editing of the HIV co-receptors CCR5 and CXCR4 by CRISPR-Cas9 protects CD4+ T cells from HIV-1 infection. Cell Biosci. 2017, 7, 1-15. [CrossRef]

130. Yu, S.; Yao, Y.; Xiao, H.; Li, J.; Liu, Q.; Yang, Y.; Adah, D.; Lu, J.; Zhao, S.; Qin, L.; et al. Simultaneous knockout of CXCR4 and CCR5 genes in CD4+ T cells via CRISPR/Cas9 confers resistance to both X4- and R5-tropic human immunodeficiency virus type 1 infection. Hum. Gene. Ther. 2018, 29, 51-67. [CrossRef]

131. Dash, P.K.; Kaminski, R.; Bella, R.; Su, H.; Mathews, S.; Ahooyi, T.M.; Chen, C.; Mancuso, P.; Sariyer, R.; Ferrante, P.; et al. Sequential LASER ART and CRISPR treatments eliminate HIV-1 in a subset of infected humanized mice. Nat. Commun. 2019, 10, 2753. [CrossRef]

132. Rusconi, S.; Giacomelli, A. CRISPR in HIV: Dangers of CCR5 deletion. Future Virol. 2020, 15, 207-209. [CrossRef]

133. Gao, Z.; Fan, M.; Das, A.T.; Herrera-Carrillo, E.; Berkhout, B. Extinction of all infectious HIV in cell culture by the CRISPR-Cas12a system with only a single CrRNA. Nucleic Acids Res. 2020, 48, 5527-5539. [CrossRef]

134. Nouri, R.; Jiang, Y.; Lian, X.L.; Guan, W. Sequence-specific recognition of HIV-1 DNA with solid-state CRISPR-Cas12a-assisted nanopores (SCAN). ACS Sens. 2020, 5, 1273-1280. [CrossRef]

135. Ding, X.; Yin, K.; Li, Z.; Liu, C. All-in-one dual CRISPR-Cas12a (AIOD-CRISPR) assay: A case for rapid, ultrasensitive and visual detection of novel Coronavirus SARS-CoV-2 and HIV Virus. bioRxiv 2020. [CrossRef]

136. Hou, T.; Zeng, W.; Yang, M.; Chen, W.; Ren, L.; Ai, J.; Wu, J.; Liao, Y.; Gou, X.; Li, Y.; et al. Development and evaluation of A CRISPR-based diagnostic for 2019-novel Coronavirus. medRxiv 2020. [CrossRef]

137. Roehm, P.C.; Shekarabi, M.; Wollebo, H.S.; Bellizzi, A.; He, L.; Salkind, J.; Khalili, K. Inhibition of HSV-1 replication by gene editing strategy. Sci. Rep. 2016, 6, 23146. [CrossRef] [PubMed]

138. Fan, C.; Tang, Y.; Wang, J.; Xiong, F.; Guo, C.; Wang, Y.; Xiang, B.; Zhou, M.; Li, X.; Wu, X.; et al. The emerging role of epstein-barr virus encoded microRNAs in nasopharyngeal carcinoma. J. Cancer 2018, 9, 2852-2864. [CrossRef]

139. Van Diemen, F.R.; Kruse, E.M.; Hooykaas, M.J.G.; Bruggeling, C.E.; Schürch, A.C.; van Ham, P.M.; Imhof, S.M.; Nijhuis, M.; Wiertz, E.J.H.J.; Lebbink, R.J. CRISPR/Cas9-mediated genome editing of herpesviruses limits productive and latent infections. PLoS Pathog. 2016, 12, e1005701. [CrossRef] [PubMed]

140. Tso, F.Y.; West, J.T.; Wood, C. Reduction of Kaposi's sarcoma-associated herpesvirus latency using CRISPR-Cas9 to edit the latency-associated nuclear antigen gene. J. Virol. 2019, 93. [CrossRef]

141. Gergen, J.; Coulon, F.; Creneguy, A.; Elain-Duret, N.; Gutierrez, A.; Pinkenburg, O.; Verhoeyen, E.; Anegon, I.; Nguyen, T.H.; Halary, F.A.; et al. Multiplex CRISPR/Cas9 system impairs HCMV replication by excising an essential viral gene. PLoS ONE 2018, 13, e0192602. [CrossRef]

142. Moffett, H.F.; Harms, C.K.; Fitzpatrick, K.S.; Tooley, M.R.; Boonyaratanakornkit, J.; Taylor, J.J. B cells engineered to express pathogen-specific antibodies protect against infection. Sci. Immunol. 2019, 4. [CrossRef]

143. Wollebo, H.S.; Bellizzi, A.; Kaminski, R.; Hu, W.; White, M.K.; Khalili, K. CRISPR/Cas9 system as an agent for eliminating polyomavirus JC infection. PLoS ONE 2015, 10, e0136046. [CrossRef]

144. Tian, X.; Gu, T.; Patel, S.; Bode, A.M.; Lee, M.-H.; Dong, Z. CRISPR/Cas9-an evolving biological tool kit for cancer biology and oncology. NPJ Precis. Oncol. 2019, 3, 8. [CrossRef] [PubMed]

145. Huang, C.-H.; Lee, K.-C.; Doudna, J.A. Applications of CRISPR-Cas enzymes in cancer therapeutics and detection. Trends Cancer 2018, 4, 499-512. [CrossRef]

146. Morris, L.G.T.; Chan, T.A. Therapeutic targeting of tumor suppressor genes. Cancer 2015, 121, 1357-1368. [CrossRef]

147. Kodama, M.; Kodama, T.; Murakami, M. Oncogene activation and tumor suppressor gene inactivation find their sites of expression in the changes in time and space of the age-adjusted cancer incidence rate. In Vivo 2000, 14, 725-734. [PubMed]

148. Bu, X.; Kato, J.; Hong, J.A.; Merino, M.J.; Schrump, D.S.; Lund, F.E.; Moss, J. CD38 knockout suppresses tumorigenesis in mice and clonogenic growth of human lung cancer cells. Carcinogenesis 2018, 39, 242-251. [CrossRef] 
149. Chen, C.H.; Changou, C.A.; Hsieh, T.H.; Lee, Y.C.; Chu, C.Y.; Hsu, K.C.; Wang, H.C.; Lin, Y.C.; Lo, Y.N.; Liu, Y.R.; et al. Dual inhibition of PIK3C3 and FGFR as a new therapeutic approach to treat bladder cancer. Clin. Cancer res. Off. J. Am. Assoc. Cancer Res. 2018, 24, 1176-1189. [CrossRef]

150. Takeda, H.; Kataoka, S.; Nakayama, M.; Ali, M.A.E.; Oshima, H.; Yamamoto, D.; Park, J.-W.; Takegami, Y.; An, T.; Jenkins, N.A.; et al. CRISPR-Cas9-mediated gene knockout in intestinal tumor organoids provides functional validation for colorectal cancer driver genes. PNAS 2019, 116, 15635-15644. [CrossRef] [PubMed]

151. Artegiani, B.; van Voorthuijsen, L.; Lindeboom, R.G.H.; Seinstra, D.; Heo, I.; Tapia, P.; López-Iglesias, C.; Postrach, D.; Dayton, T.; Oka, R.; et al. Probing the tumor suppressor function of BAP1 in CRISPR-engineered human liver organoids. Cell Stem. Cell 2019, 24, 927-943.e6. [CrossRef] [PubMed]

152. Eyquem, J.; Mansilla-Soto, J.; Giavridis, T.; van der Stegen, S.J.C.; Hamieh, M.; Cunanan, K.M.; Odak, A.; Gönen, M.; Sadelain, M. Targeting a CAR to the TRAC Locus with CRISPR/Cas9 enhances tumour rejection. Nature 2017, 543, 113-117. [CrossRef] [PubMed]

153. Ren, J.; Liu, X.; Fang, C.; Jiang, S.; June, C.H.; Zhao, Y. Multiplex genome editing to generate universal CAR T cells resistant to PD1 inhibition. Clin. Cancer Res. 2017, 23, 2255-2266. [CrossRef]

154. Rupp, L.J.; Schumann, K.; Roybal, K.T.; Gate, R.E.; Ye, C.J.; Lim, W.A.; Marson, A. CRISPR/Cas9-Mediated PD-1 disruption enhances anti-tumor efficacy of human chimeric antigen receptor T cells. Sci. Rep. 2017, 7, 737. [CrossRef] [PubMed]

155. Huang, R.-Y.; Francois, A.; McGray, A.R.; Miliotto, A.; Odunsi, K. Compensatory upregulation of PD-1, LAG-3, and CTLA-4 limits the efficacy of single-agent checkpoint blockade in metastatic ovarian cancer. Oncoimmunology 2017, 6, e1249561. [CrossRef] [PubMed]

156. Zhang, W.; Liu, Y.; Zhou, X.; Zhao, R.; Wang, H. Applications of CRISPR-Cas9 in gynecological cancer research. Clin. Genet 2020, 97, 827-834. [CrossRef]

157. Firth, A.L.; Menon, T.; Parker, G.S.; Qualls, S.J.; Lewis, B.M.; Ke, E.; Dargitz, C.T.; Wright, R.; Khanna, A.; Gage, F.H.; et al. Functional gene correction for cystic fibrosis in lung epithelial cells generated from patient IPSCs. Cell Rep. 2015, 12, 1385-1390. [CrossRef]

158. Duchêne, B.L.; Cherif, K.; Iyombe-Engembe, J.-P.; Guyon, A.; Rousseau, J.; Ouellet, D.L.; Barbeau, X.; Lague, P.; Tremblay, J.P. CRISPR-induced deletion with SaCas9 restores dystrophin expression in dystrophic models in vitro and in vivo. Mol. Ther. 2018, 26, 2604-2616. [CrossRef]

159. Long, C.; Li, H.; Tiburcy, M.; Rodriguez-Caycedo, C.; Kyrychenko, V.; Zhou, H.; Zhang, Y.; Min, Y.-L.; Shelton, J.M.; Mammen, P.P.A.; et al. Correction of diverse muscular dystrophy mutations in human engineered heart muscle by single-site genome editing. Sci. Adv. 2018, 4, eaap9004. [CrossRef]

160. Frangoul, H.; Altshuler, D.; Cappellini, M.D.; Chen, Y.-S.; Domm, J.; Eustace, B.K.; Foell, J.; de la Fuente, J.; Grupp, S.; Handgretinger, R.; et al. CRISPR-Cas9 gene editing for sickle cell disease and $\beta$-thalassemia. N. Engl. J. Med. 2021, 384, 252-260. [CrossRef]

161. Vilarino, M.; Suchy, F.P.; Rashid, S.T.; Lindsay, H.; Reyes, J.; McNabb, B.R.; van der Meulen, T.; Huising, M.O.; Nakauchi, H.; Ross, P.J. Mosaicism diminishes the value of pre-implantation embryo biopsies for detecting CRISPR/Cas9 induced mutations in sheep. Transgenic Res. 2018, 27, 525-537. [CrossRef]

162. Haston, S.; Pozzi, S.; Gonzalez-Meljem, J.M. Applications of CRISPR-cas in ageing research. Clin. Genet. Genom. Aging 2020, 213-230. [CrossRef]

163. Yue, Y.; Kan, Y.; Xu, W.; Zhao, H.-Y.; Zhou, Y.; Song, X.; Wu, J.; Xiong, J.; Goswami, D.; Yang, M.; et al. Extensive mammalian germline genome engineering. bioRxiv 2019. [CrossRef]

164. Skill, N.; Kubal, S.; Fridell, J.; Ekser, B. Identification of novel xenoreactive non-gal antigens: Tetraspanin CD37 and CD81. Xenotransplantation 2017, 24, 27-28. [CrossRef]

165. Ul Ain, Q.; Chung, J.Y.; Kim, Y.-H. Current and future delivery systems for engineered nucleases: ZFN, TALEN and RGEN. J. Control. Release 2015, 205, 120-127. [CrossRef] [PubMed]

166. Wu, Y.; Zhou, H.; Fan, X.; Zhang, Y.; Zhang, M.; Wang, Y.; Xie, Z.; Bai, M.; Yin, Q.; Liang, D.; et al. Correction of a genetic disease by CRISPR-Cas9-mediated gene editing in mouse spermatogonial stem cells. Cell Res. 2015, 25, 67-79. [CrossRef] [PubMed]

167. Flynn, R.; Grundmann, A.; Renz, P.; Hänseler, W.; James, W.S.; Cowley, S.A.; Moore, M.D. CRISPR-mediated genotypic and phenotypic correction of a chronic granulomatous disease mutation in human IPS cells. Exp. Hematol. 2015, 43, 838-848. [CrossRef]

168. Wang, S.; Cheng, Z.-Y.; Zhao, Z.-N.; Quan, X.-Q.; Wei, Y.; Xia, D.-S.; Li, J.-Q.; Hu, J.-L. Correlation of serum PCSK9 in CHD patients with the severity of coronary arterial lesions. Eur. Rev. Med. Pharmacol. Sci. 2016, 20, 1135-1139.

169. Van Agtmaal, E.L.; André, L.M.; Willemse, M.; Cumming, S.A.; van Kessel, I.D.G.; van den Broek, W.J.A.A.; Gourdon, G.; Furling, D.; Mouly, V.; Monckton, D.G.; et al. CRISPR/Cas9-Induced (CTG.CAG)n repeat instability in the myotonic dystrophy type 1 locus: Implications for therapeutic genome editing. Mol. Ther. 2017, 25, 24-43. [CrossRef] [PubMed]

170. Li, H.L.; Fujimoto, N.; Sasakawa, N.; Shirai, S.; Ohkame, T.; Sakuma, T.; Tanaka, M.; Amano, N.; Watanabe, A.; Sakurai, H.; et al. Precise correction of the dystrophin gene in duchenne muscular dystrophy patient induced pluripotent stem cells by TALEN and CRISPR-Cas9. Stem. Cell Rep. 2015, 4, 143-154. [CrossRef]

171. Monteys, A.M.; Ebanks, S.A.; Keiser, M.S.; Davidson, B.L. CRISPR/Cas9 editing of the mutant huntingtin allele in vitro and in vivo. Mol. Ther. 2017, 25, 12-23. [CrossRef] 
172. Canver, M.C.; Smith, E.C.; Sher, F.; Pinello, L.; Sanjana, N.E.; Shalem, O.; Chen, D.D.; Schupp, P.G.; Vinjamur, D.S.; Garcia, S.P.; et al. BCL11A enhancer dissection by Cas9-mediated in situ saturating mutagenesis. Nature 2015, 527, 192-197. [CrossRef]

173. Xie, C.; Zhang, Y.-P.; Song, L.; Luo, J.; Qi, W.; Hu, J.; Lu, D.; Yang, Z.; Zhang, J.; Xiao, J.; et al. Genome editing with CRISPR/Cas9 in postnatal mice corrects PRKAG2 cardiac syndrome. Cell Res. 2016, 26, 1099-1111. [CrossRef]

174. Liu, Y.; Yang, Y.; Kang, X.; Lin, B.; Yu, Q.; Song, B.; Gao, G.; Chen, Y.; Sun, X.; Li, X.; et al. One-step biallelic and scarless correction of a $\beta$-thalassemia mutation in patient-specific IPSCs without drug selection. Mol. Ther. Nucleic Acids 2017, 6, 57-67. [CrossRef]

175. Lavin, M.F.; Yeo, A.J.; Kijas, A.W.; Wolvetang, E.; Sly, P.D.; Wainwright, C.; Sinclair, K. Therapeutic targets and investigated treatments for ataxia-telangiectasia. Expert Opin. Orphan Drugs 2016, 4, 1263-1276. [CrossRef]

176. Zhen, S.; Hua, L.; Takahashi, Y.; Narita, S.; Liu, Y.-H.; Li, Y. In vitro and in vivo growth suppression of human Papillomavirus 16-positive cervical cancer cells by CRISPR/Cas9. Biochem. Biophys. Res. Commun. 2014, 450, 1422-1426. [CrossRef]

177. Ma, H.; Marti-Gutierrez, N.; Park, S.-W.; Wu, J.; Lee, Y.; Suzuki, K.; Koski, A.; Ji, D.; Hayama, T.; Ahmed, R.; et al. Correction of a pathogenic gene mutation in human embryos. Nature 2017, 548, 413-419. [CrossRef]

178. Miyamoto, T.; Akutsu, S.N.; Tauchi, H.; Kudo, Y.; Tashiro, S.; Yamamoto, T.; Matsuura, S. Exploration of genetic basis underlying individual differences in radiosensitivity within human populations using genome editing technology. J. Radiat. Res. 2018, 59, ii75-ii82. [CrossRef] [PubMed]

179. Li, F.; Ng, W.-L.; Luster, T.A.; Hu, H.; Sviderskiy, V.O.; Dowling, C.M.; Hollinshead, K.E.R.; Zouitine, P.; Zhang, H.; Huang, Q.; et al. Epigenetic CRISPR screens identify Npm1 as a therapeutic vulnerability in non-small cell lung cancer. Cancer Res. 2020, 80, 3556-3567. [CrossRef]

180. You, L.; Tong, R.; Li, M.; Liu, Y.; Xue, J.; Lu, Y. Advancements and obstacles of CRISPR-Cas9 technology in translational research. Mol. Ther. Methods Clin. Dev. 2019, 13, 359-370. [CrossRef] [PubMed]

181. Li, H.; Sheng, C.; Wang, S.; Yang, L.; Liang, Y.; Huang, Y.; Liu, H.; Li, P.; Yang, C.; Yang, X.; et al. Removal of integrated hepatitis B virus DNA using CRISPR-Cas9. Front. Cell Infect. Microbiol. 2017, 7, 91. [CrossRef] [PubMed]

182. Gomaa, A.A.; Klumpe, H.E.; Luo, M.L.; Selle, K.; Barrangou, R.; Beisel, C.L. Programmable removal of bacterial strains by use of genome-targeting CRISPR-cas systems. mBio 2014, 5. [CrossRef]

183. Yosef, I.; Manor, M.; Kiro, R.; Qimron, U. Temperate and lytic bacteriophages programmed to sensitize and kill antibiotic-resistant bacteria. PNAS 2015, 112, 7267-7272. [CrossRef]

184. Kim, J.-S.; Cho, D.-H.; Park, M.; Chung, W.-J.; Shin, D.; Ko, K.S.; Kweon, D.-H. CRISPR/Cas9-mediated re-sensitization of antibiotic-resistant Escherichia coli harboring extended-spectrum $\beta$-lactamases. J. Microbiol. Biotechnol. 2016, $26,394-401$. [CrossRef]

185. Bikard, D.; Euler, C.; Jiang, W.; Nussenzweig, P.M.; Goldberg, G.W.; Duportet, X.; Fischetti, V.A.; Marraffini, L.A. Development of sequence-specific antimicrobials based on programmable CRISPR-cas nucleases. Nat. Biotechnol. 2014, 32, 1146-1150. [CrossRef] [PubMed]

186. Li, D.; Li, X.; Zhou, W.-L.; Huang, Y.; Liang, X.; Jiang, L.; Yang, X.; Sun, J.; Li, Z.; Han, W.-D.; et al. Genetically engineered T cells for cancer immunotherapy. Signal Transduct. Target. Ther. 2019, 4, 1-17. [CrossRef] [PubMed]

187. Kyrou, K.; Hammond, A.M.; Galizi, R.; Kranjc, N.; Burt, A.; Beaghton, A.K.; Nolan, T.; Crisanti, A. A CRISPR-Cas9 gene drive targeting doublesex causes complete population suppression in caged Anopheles gambiae mosquitoes. Nat. Biotechnol. 2018, 36, 1062-1066. [CrossRef] [PubMed]

188. Jakočiūnas, T.; Jensen, M.K.; Keasling, J.D. CRISPR/Cas9 advances engineering of microbial cell factories. Metab. Eng. 2016, 34, 44-59. [CrossRef] [PubMed]

189. Jakočiūnas, T.; Bonde, I.; Herrgård, M.; Harrison, S.J.; Kristensen, M.; Pedersen, L.E.; Jensen, M.K.; Keasling, J.D. Multiplex metabolic pathway engineering using CRISPR/Cas9 in Saccharomyces cerevisiae. Metab. Eng. 2015, 28, 213-222. [CrossRef]

190. Li, Y.; Lin, Z.; Huang, C.; Zhang, Y.; Wang, Z.; Tang, Y.-J.; Chen, T.; Zhao, X. Metabolic engineering of Escherichia coli using CRISPR-Cas9 meditated genome editing. Metab. Eng. 2015, 31, 13-21. [CrossRef]

191. Cho, J.S.; Choi, K.R.; Prabowo, C.P.S.; Shin, J.H.; Yang, D.; Jang, J.; Lee, S.Y. CRISPR/Cas9-coupled recombineering for metabolic engineering of Corynebacterium glutamicum. Metab. Eng. 2017, 42, 157-167. [CrossRef]

192. Ferreira, R.; David, F.; Nielsen, J. Advancing Biotechnology with CRISPR/Cas9: Recent applications and patent landscape. J. Ind. Microbiol. Biotechnol. 2018, 45, 467-480. [CrossRef]

193. Kuivanen, J.; Wang, Y.-M.J.; Richard, P. Engineering Aspergillus niger for galactaric acid production: Elimination of galactaric acid catabolism by using RNA sequencing and CRISPR/Cas9. Microb. Cell Factories 2016, 15, 210. [CrossRef]

194. Siripong, W.; Angela, C.; Tanapongpipat, S.; Runguphan, W. Metabolic engineering of Pichia pastoris for production of isopentanol (3-Methyl-1-Butanol). Enzyme Microb. Technol. 2020, 138, 109557. [CrossRef]

195. Xu, P.; Li, L.; Zhang, F.; Stephanopoulos, G.; Koffas, M. Improving fatty acids production by engineering dynamic pathway regulation and metabolic control. PNAS 2014, 111, 11299-11304. [CrossRef] [PubMed]

196. Jiménez, A.; Muñoz-Fernández, G.; Ledesma-Amaro, R.; Buey, R.M.; Revuelta, J.L. One-Vector CRISPR/Cas9 genome engineering of the industrial fungus Ashbya gossypii. Microb. Biotechnol. 2019, 12, 1293-1301. [CrossRef] [PubMed]

197. Liu, W.; An, C.; Shu, X.; Meng, X.; Yao, Y.; Zhang, J.; Chen, F.; Xiang, H.; Yang, S.; Gao, X.; et al. A dual-plasmid CRISPR/cas system for mycotoxin elimination in polykaryotic industrial fungi. ACS Synth. Biol. 2020, 9, 2087-2095. [CrossRef]

198. Li, C.; Zhang, R.; Meng, X.; Chen, S.; Zong, Y.; Lu, C.; Qiu, J.-L.; Chen, Y.-H.; Li, J.; Gao, C. Targeted, random mutagenesis of plant genes with dual cytosine and adenine base editors. Nat. Biotechnol. 2020, 38, 875-882. [CrossRef] [PubMed] 
199. Mougiakos, I.; Mohanraju, P.; Bosma, E.F.; Vrouwe, V.; Finger Bou, M.; Naduthodi, M.I.S.; Gussak, A.; Brinkman, R.B.L.; van Kranenburg, R.; van der Oost, J. Characterizing a thermostable Cas9 for bacterial genome editing and silencing. Nat. Commun. 2017, 8, 1647. [CrossRef]

200. Lim, H.; Choi, S.-K. Programmed GRNA removal system for CRISPR-Cas9-mediated multi-round genome editing in Bacillus subtilis. Front. Microbiol. 2019, 10. [CrossRef] [PubMed]

201. Altenbuchner, J. Editing of the Bacillus subtilis genome by the CRISPR-Cas9 system. Appl. Environ. Microbiol. 2016, 82, 5421-5427. [CrossRef]

202. Nagaraju, S.; Davies, N.K.; Walker, D.J.F.; Köpke, M.; Simpson, S.D. Genome editing of Clostridium autoethanogenum using CRISPR/Cas9. Biotechnol. Biofuels 2016, 9, 219. [CrossRef]

203. Wang, Y.; Zhang, Z.-T.; Seo, S.-O.; Lynn, P.; Lu, T.; Jin, Y.-S.; Blaschek, H.P. Gene transcription repression in Clostridium beijerinckii using CRISPR-DCas9. Biotechnol. Bioeng. 2016, 113, 2739-2743. [CrossRef] [PubMed]

204. Xu, C.; Huang, R.; Teng, L.; Jing, X.; Hu, J.; Cui, G.; Wang, Y.; Cui, Q.; Xu, J. Cellulosome stoichiometry in clostridium cellulolyticum is regulated by selective RNA processing and stabilization. Nat. Commun. 2015, 6, 6900. [CrossRef]

205. Huang, H.; Chai, C.; Li, N.; Rowe, P.; Minton, N.P.; Yang, S.; Jiang, W.; Gu, Y. CRISPR/Cas9-based efficient genome editing in Clostridium ljungdahlii, an autotrophic gas-fermenting bacterium. ACS Synth. Biol. 2016, 5, 1355-1361. [CrossRef] [PubMed]

206. Pyne, M.E.; Sokolenko, S.; Liu, X.; Srirangan, K.; Bruder, M.R.; Aucoin, M.G.; Moo-Young, M.; Chung, D.A.; Chou, C.P. Disruption of the reductive 1,3-propanediol pathway triggers production of 1,2-propanediol for sustained glycerol fermentation by Clostridium Ppasteurianum. Appl. Environ. Microbiol. 2016, 82, 5375-5388. [CrossRef]

207. Cleto, S.; Jensen, J.V.; Wendisch, V.F.; Lu, T.K. Corynebacterium Gglutamicum metabolic engineering with CRISPR interference (CRISPRi). ACS Synth. Biol. 2016, 5, 375-385. [CrossRef]

208. Li, H.; Shen, C.R.; Huang, C.-H.; Sung, L.-Y.; Wu, M.-Y.; Hu, Y.-C. CRISPR-Cas9 for the genome engineering of cyanobacteria and succinate production. Metabol. Eng. 2016, 38, 293-302. [CrossRef]

209. Zhang, S.; Guo, F.; Yan, W.; Dai, Z.; Dong, W.; Zhou, J.; Zhang, W.; Xin, F.; Jiang, M. Recent advances of CRISPR/Cas9-based genetic engineering and transcriptional regulation in industrial biology. Front. Bioeng. Biotechnol. 2020, 7. [CrossRef]

210. Donohoue, P.D.; Barrangou, R.; May, A.P. Advances in industrial biotechnology using CRISPR-cas systems. Trends Biotechnol. 2018, 36, 134-146. [CrossRef]

211. Oh, J.-H.; van Pijkeren, J.-P. CRISPR-Cas9-assisted recombineering in Lactobacillus reuteri. Nucleic Acids Res. 2014,42, e131. [CrossRef] [PubMed]

212. Hao, M.; Cui, Y.; Qu, X. Analysis of CRISPR-cas system in Streptococcus thermophilus and its application. Front. Microbiol. 2018, 9, 257. [CrossRef]

213. Zhang, M.M.; Wong, F.T.; Wang, Y.; Luo, S.; Lim, Y.H.; Heng, E.; Yeo, W.L.; Cobb, R.E.; Enghiad, B.; Ang, E.L.; et al. CRISPR-Cas9 strategy for activation of silent Streptomyces biosynthetic gene clusters. Nat. Chem. Biol. 2017, 13, 607-609. [CrossRef] [PubMed]

214. Huang, H.; Zheng, G.; Jiang, W.; Hu, H.; Lu, Y. One-step high-efficiency CRISPR/Cas9-mediated genome editing in Streptomyces Acta Biochim. Biophys. Sin. 2015, 47, 231-243. [CrossRef] [PubMed]

215. Jia, H.; Zhang, L.; Wang, T.; Han, J.; Tang, H.; Zhang, L. Development of a CRISPR/Cas9-mediated gene-editing tool in Streptomyces rimosus. Microbiology 2017, 163, 1148-1155. [CrossRef] [PubMed]

216. Lim, Y.H.; Wong, F.T.; Yeo, W.L.; Ching, K.C.; Lim, Y.W.; Heng, E.; Chen, S.; Tsai, D.-J.; Lauderdale, T.-L.; Shia, K.-S.; et al. Auroramycin: A potent antibiotic from Streptomyces roseosporus by CRISPR-Cas9 activation. ChemBioChem 2018, 19, 1716-1719. [CrossRef]

217. Zhang, Y.; Sun, X.; Wang, Q.; Xu, J.; Dong, F.; Yang, S.; Yang, J.; Zhang, Z.; Qian, Y.; Chen, J.; et al. Multicopy chromosomal integration using CRISPR-associated transposases. ACS Synth. Biol. 2020, 9, 1998-2008. [CrossRef]

218. Jiang, Y.; Chen, B.; Duan, C.; Sun, B.; Yang, J.; Yang, S. Multigene editing in the Escherichia coli genome via the CRISPR-Cas9 system. Appl. Environ. Microbiol. 2015, 81, 2506-2514. [CrossRef]

219. Wenderoth, M.; Pinecker, C.; Voß, B.; Fischer, R. Establishment of CRISPR/Cas9 in Alternaria alternata. Fungal Genet. Biol. 2017, 101, 55-60. [CrossRef]

220. Nødvig, C.S.; Nielsen, J.B.; Kogle, M.E.; Mortensen, U.H. A CRISPR-Cas9 system for genetic engineering of filamentous fungi. PLoS ONE 2015, 10, e0133085. [CrossRef]

221. Nødvig, C.S.; Hoof, J.B.; Kogle, M.E.; Jarczynska, Z.D.; Lehmbeck, J.; Klitgaard, D.K.; Mortensen, U.H. Efficient oligo nucleotide mediated CRISPR-Cas9 gene editing in aspergilli. Fungal Genet. Biol. 2018, 115, 78-89. [CrossRef]

222. Weyda, I.; Yang, L.; Vang, J.; Ahring, B.K.; Lübeck, M.; Lübeck, P.S. A comparison of agrobacterium-mediated transformation and protoplast-mediated transformation with CRISPR-Cas9 and bipartite gene targeting substrates, as effective gene targeting tools for Aspergillus carbonarius. J. Microbiol. Methods 2017, 135, 26-34. [CrossRef]

223. Fuller, K.K.; Chen, S.; Loros, J.J.; Dunlap, J.C. Development of the CRISPR/Cas9 system for targeted gene disruption in Aspergillus fumigatus. Eukaryot. Cell 2015, 14, 1073-1080. [CrossRef] [PubMed]

224. Kadooka, C.; Yamaguchi, M.; Okutsu, K.; Yoshizaki, Y.; Takamine, K.; Katayama, T.; Maruyama, J.-I.; Tamaki, H.; Futagami, T. A CRISPR/Cas9-mediated gene knockout system in Aspergillus luchuensis mut. Kawachii. Biosci. Biotechnol. Biochem. 2020, 84, 2179-2183. [CrossRef] [PubMed] 
225. Katayama, T.; Tanaka, Y.; Okabe, T.; Nakamura, H.; Fujii, W.; Kitamoto, K.; Maruyama, J. Development of a genome editing technique using the CRISPR/Cas9 system in the industrial filamentous fungus Aspergillus oryzae. Biotechnol. Lett. 2016, 38, 637-642. [CrossRef]

226. Min, K.; Ichikawa, Y.; Woolford, C.A.; Mitchell, A.P. Candida albicans gene deletion with a transient CRISPR-Cas9 System. mSphere 2016, 1. [CrossRef]

227. Enkler, L.; Richer, D.; Marchand, A.L.; Ferrandon, D.; Jossinet, F. Genome engineering in the yeast pathogen Candida glabrata using the CRISPR-Cas9 System. Sci Rep 2016, 6, 35766. [CrossRef] [PubMed]

228. Wang, Y.; Wei, D.; Zhu, X.; Pan, J.; Zhang, P.; Huo, L.; Zhu, X. A ‘Suicide' CRISPR-Cas9 system to promote gene deletion and restoration by electroporation in Cryptococcus neoformans. Sci. Rep. 2016, 6, 31145. [CrossRef]

229. Shi, T.-Q.; Gao, J.; Wang, W.-J.; Wang, K.-F.; Xu, G.-Q.; Huang, H.; Ji, X.-J. CRISPR/Cas9-based genome editing in the filamentous Fungus Fusarium fujikuroi and its application in strain engineering for gibberellic acid production. ACS Synth. Biol. 2019, 8, 445-454. [CrossRef]

230. Qin, H.; Xiao, H.; Zou, G.; Zhou, Z.; Zhong, J.-J. CRISPR-Cas9 assisted gene disruption in the higher fungus Ganoderma species. Process Biochem. 2017, 56, 57-61. [CrossRef]

231. Wilson, A.M.; Wingfield, B.D. CRISPR-Cas9-mediated genome editing in the Filamentous Ascomycete Huntiella omanensis. J. Vis. Exp. 2020. [CrossRef] [PubMed]

232. Horwitz, A.A.; Walter, J.M.; Schubert, M.G.; Kung, S.H.; Hawkins, K.; Platt, D.M.; Hernday, A.D.; Mahatdejkul-Meadows, T.; Szeto, W.; Chandran, S.S.; et al. Efficient multiplexed integration of synergistic alleles and metabolic pathways in yeasts via CRISPR-Cas. Cell Syst. 2015, 1, 88-96. [CrossRef]

233. Liu, Q.; Gao, R.; Li, J.; Lin, L.; Zhao, J.; Sun, W.; Tian, C. Development of a genome-editing CRISPR/Cas9 system in thermophilic fungal Myceliophthora species and its application to hyper-cellulase production strain engineering. Biotechnol. Biofuels 2017, 10, 1. [CrossRef]

234. Matsu-ura, T.; Baek, M.; Kwon, J.; Hong, C. Efficient gene editing in Neurospora crassa with CRISPR technology. Fungal Biol. Biotechnol. 2015, 2, s40694-s40715. [CrossRef]

235. Pohl, C.; Kiel, J.A.K.W.; Driessen, A.J.M.; Bovenberg, R.A.L.; Nygård, Y. CRISPR/Cas9 based genome editing of Penicillium chrysogenum. ACS Synth. Biol. 2016, 5, 754-764. [CrossRef]

236. Fang, Y.; Tyler, B.M. Efficient disruption and replacement of an effector gene in the oomycete Phytophthora sojae using CRISPR/Cas9. Mol. Plant Pathol. 2016, 17, 127-139. [CrossRef]

237. Jacobs, J.Z.; Ciccaglione, K.M.; Tournier, V.; Zaratiegui, M. Implementation of the CRISPR-Cas9 System in fission yeast. Nat. Commun. 2014, 5, 5344. [CrossRef] [PubMed]

238. Nielsen, M.L.; Isbrandt, T.; Rasmussen, K.B.; Thrane, U.; Hoof, J.B.; Larsen, T.O.; Mortensen, U.H. Genes linked to production of secondary metabolites in Talaromyces atroroseus revealed using CRISPR-Cas9. PLoS ONE 2017, 12, e0169712. [CrossRef] [PubMed]

239. Liu, R.; Chen, L.; Jiang, Y.; Zhou, Z.; Zou, G. Efficient genome editing in Filamentous Fungus Trichoderma reesei Uusing the CRISPR/Cas9 System. Cell Discov. 2015, 1, 1-11. [CrossRef]

240. Schuster, M.; Schweizer, G.; Reissmann, S.; Kahmann, R. Genome editing in Ustilago maydis using the CRISPR-cas system. Fungal. Genet. Biol. 2016, 89, 3-9. [CrossRef] [PubMed]

241. Schwartz, C.M.; Hussain, M.S.; Blenner, M.; Wheeldon, I. Synthetic RNA Polymerase III promoters facilitate high-efficiency CRISPR-Cas9-mediated genome editing in Yarrowia lipolytica. ACS Synth. Biol. 2016, 5, 356-359. [CrossRef]

242. Kim, Y.G.; Cha, J.; Chandrasegaran, S. Hybrid restriction enzymes: Zinc finger fusions to fok I Cleavage domain. PNAS 1996, 93, 1156-1160. [CrossRef] [PubMed]

243. Cermak, T.; Doyle, E.L.; Christian, M.; Wang, L.; Zhang, Y.; Schmidt, C.; Baller, J.A.; Somia, N.V.; Bogdanove, A.J.; Voytas, D.F. Efficient design and assembly of custom TALEN and Other TAL effector-based constructs for DNA Targeting. Nucleic Acids Res. 2011, 39, e82. [CrossRef]

244. Wang, H.; La Russa, M.; Qi, L.S. CRISPR/Cas9 in genome editing and beyond. Annu. Rev. Biochem. 2016, 85, 227-264. [CrossRef]

245. Sakuma, T.; Nishikawa, A.; Kume, S.; Chayama, K.; Yamamoto, T. Multiplex genome engineering in human cells using all-in-one CRISPR/Cas9 Vector System. Sci. Rep. 2014, 4, 5400. [CrossRef] [PubMed]

246. Poirier, J.T. CRISPR libraries and screening. Prog. Mol. Biol. Transl. Sci. 2017, 152, 69-82. [CrossRef]

247. Zhang, J.-H.; Adikaram, P.; Pandey, M.; Genis, A.; Simonds, W.F. Optimization of genome editing through CRISPR-Cas9 engineering. Bioengineered 2016, 7, 166-174. [CrossRef]

248. Zhu, H.; Li, C.; Gao, C. Applications of CRISPR-cas in agriculture and plant biotechnology. Nat. Rev. Mol. Cell Biol. 2020, 21, 661-677. [CrossRef]

249. Sedeek, K.E.M.; Mahas, A.; Mahfouz, M. Plant genome engineering for targeted improvement of crop traits. Front. Plant Sci. 2019, 10. [CrossRef]

250. FAOSTAT. Available online: http:/ / www.fao.org/faostat/en/\#data/RL (accessed on 11 March 2021).

251. Biotech Crop Highlights in 2018 I ISAAA.Org. Available online: https://www.isaaa.org/resources/publications/pocketk/16/ (accessed on 14 March 2021).

252. PubMed. Available online: https:// pubmed.ncbi.nlm.nih.gov/ (accessed on 14 March 2021).

253. Cho, S.W.; Kim, S.; Kim, Y.; Kweon, J.; Kim, H.S.; Bae, S.; Kim, J.-S. Analysis of off-target effects of CRISPR/Cas-Derived RNA-guided endonucleases and nickases. Genome Res. 2014, 24, 132-141. [CrossRef] [PubMed] 
254. Soga, K.; Nakamura, K.; Ishigaki, T.; Kimata, S.; Ohmori, K.; Kishine, M.; Mano, J.; Takabatake, R.; Kitta, K.; Nagoya, H.; et al. Development of a novel method for specific detection of genetically modified atlantic salmon, aquadvantage, using real-time polymerase chain reaction. Food Chem. 2020, 305, 125426. [CrossRef]

255. Caplan, A.L.; Parent, B.; Shen, M.; Plunkett, C. No time to waste-the ethical challenges created by CRISPR. EMBO Rep. 2015, 16, 1421-1426. [CrossRef]

256. Scudellari, M. Self-destructing mosquitoes and sterilized rodents: The promise of gene drives. Nature 2019, 571, 160-162. [CrossRef]

257. Schleidgen, S.; Dederer, H.-G.; Sgodda, S.; Cravcisin, S.; Lüneburg, L.; Cantz, T.; Heinemann, T. Human germline editing in the era of CRISPR-Cas: Risk and uncertainty, inter-generational responsibility, therapeutic legitimacy. BMC Med. Ethics 2020, 21, 87. [CrossRef]

258. Furtado, R.N.; Furtado, R.N. Gene Editing: The risks and benefits of modifying human DNA. Rev. Bioética 2019, 27, $223-233$. [CrossRef]

259. Locke, L.G. The Promise of CRISPR for human germline editing and the perils of "Playing God". CRISPR J. 2020, 3, 27-31. [CrossRef]

260. Ihry, R.J.; Worringer, K.A.; Salick, M.R.; Frias, E.; Ho, D.; Theriault, K.; Kommineni, S.; Chen, J.; Sondey, M.; Ye, C.; et al. P53 Inhibits CRISPR-Cas9 engineering in human pluripotent stem cells. Nat. Med. 2018, 24, 939-946. [CrossRef]

261. Haapaniemi, E.; Botla, S.; Persson, J.; Schmierer, B.; Taipale, J. CRISPR-Cas9 genome editing induces a P53-mediated DNA damage response. Nat. Med. 2018, 24, 927-930. [CrossRef]

262. Fu, Y.; Foden, J.A.; Khayter, C.; Maeder, M.L.; Reyon, D.; Joung, J.K.; Sander, J.D. High-frequency off-target mutagenesis induced by CRISPR-cas nucleases in human cells. Nat. Biotechnol. 2013, 31, 822-826. [CrossRef] [PubMed]

263. Ferdosi, S.R.; Ewaisha, R.; Moghadam, F.; Krishna, S.; Park, J.G.; Ebrahimkhani, M.R.; Kiani, S.; Anderson, K.S. Multifunctional CRISPR-Cas9 with engineered immunosilenced human T cell epitopes. Nat. Commun. 2019, 10, 1-10. [CrossRef]

264. Pawluk, A.; Davidson, A.R.; Maxwell, K.L. Anti-CRISPR: Discovery, mechanism and function. Nat. Rev. Microbiol. 2018, 16, 12-17. [CrossRef]

265. DiEuliis, D.; Giordano, J. Why gene editors like CRISPR/Cas may be a game-changer for neuroweapons. Health Secur. 2017, 15, 296-302. [CrossRef]

266. DiEuliis, D.; Giordano, J. Gene editing using CRISPR/Cas9: Implications for dual-use and biosecurity. Protein Cell 2018, 9, 239-240. [CrossRef] [PubMed]

267. West, R.M.; Gronvall, G.K. CRISPR Cautions: Biosecurity implications of gene editing. Perspect. Biol. Med. 2020, 63, 73-92. [CrossRef] [PubMed]

268. Ayanoğlu, F.B.; Elçin, A.E.; Elçin, Y.M. Bioethical issues in genome editing by CRISPR-Cas9 technology. Turk. J. Biol. 2020, 44, 110-120. [CrossRef] 